\title{
Geçici Koruma Altındaki Suriye Vatandaşlarının Çocuk Yaşta Evliliklerinin Mukayeseli Hukuka ve Türk Hukukuna Göre Geçerliliği
}

\author{
Ayşe Elif Ulusu Karataş* (i)
}

Öz

Bu çalışmada; Türkiye'de geçici koruma altında bulunan Suriyelilerin yapttkları ve giderek artan çocuk yaşta evliliklerin hukuki boyutu ele alınacaktr. Bu kapsamda; Suriyelilerin Türkiye'ye gelmeden önce veya geldikten sonra yaptkları çocuk yaşta evliliklerin geçerliliğine uygulanacak hukukun belirlenmesine ilişkin meselelere, Türk kanunlar ihtilafi kuralları çerçevesinde mukayeseli hukuktan da yararlanılarak çözüm getirilmeye çalışılacaktır. Bu meseleler arasında; Türk hukukuna göre, "geçici koruma statüsü" verilen ve "mülteci" olarak kabul edilmeyen Suriyelilerin "şahsi statüsü"ne uygulanacak hukukun tespiti üzerinde özel olarak durulacaktr. Bunun yanında; evlenme yaşına uygulanacak hukukun Suriye hukuku olarak belirlendiği hallerde, Suriye hukukunda yer alan evlenme yaşına ilişkin hükümlerin uygulanmasında Türk kamu düzenine aykırılık istisnası ve bu kapsamda "çocuğun üstün menfaatinin korunması" ilkesinin rolü de özel olarak değerlendirilecektir. Ayrıca, çocuk yaşta evliliklerin Türk hukukunda tanınmamasının neticeleri, AiHS $m 8$ uyarınca "aile hayatına saygı hakkı" çerçevesinde değerlendirilecektir. Bunlara ek olarak; İsviçre, Hollanda ve Alman hukuklarında, çocuk yaşta evliliklerle mücadele etmek üzere son yıllarda gerçekleştirilen mevzuat değişiklikleri incelenecektir. Bu mevzuat değişikliklerinden; özellikle, yabancı ülkede yapılan çocuk yaşta evliliklerin geçerliliğine yetkili yabancı hukukun uygulanmasında kamu düzenine aykııılık değerlendirmesini dışlamaya yönelik hükümler içeren düzenlemeler ele alınacak ve Türk hukukunda bu kapsamda atılabilecek adımlara örnek teşkil edip etmeyecekleri değerlendirilecektir.

\section{Anahtar Kelimeler}

Çocuk yaşta evlilik, Geçici koruma statüsü, Mülteci, Suriyeliler, Evlenme yaşı, Evlenmeye uygulanacak hukuk, Milli hukuk, Kamu düzeni, Çocuğun üstün menfaati, Aile hayatına saygı hakkı

\section{Validity of Child Marriages of Syrians Under Temporary Protection in Comparative and Turkish Law}

\begin{abstract}
Due to the increasing numbers this article focuses on the legal aspects of child marriages contracted by Syrians under "temporary protection" in Turkey. In this context, the legal issues regarding the determination of applicable law to the validity of child marriages conducted in Turkey or abroad by the Syrians will be investigated within the framework of Turkish Private International Law with a comparative law perspective. Among these legal issues, special emphasis will be put on the governing law of the personal status of Syrians in Turkey since they are granted "temporary protection status" and not recognized as "refugees" under Turkish law. Another special emphasis will be put on the public policy (ordre public) exception during the application of Syrian law and rules on marriage age and the role of "the protection of the best-interests-of-the-child" principle. Furthermore the impact of the non-recognition of child marriages will be explored in the context of "the right to respect for family life" of ECHR Art 8. In addition, the legislative measures recently adopted to combat and prevent the recognition of child marriages under Swiss, Dutch and German laws will be revealed. These legislative measures, especially those aimed at eliminating the public policy exception in determining the applicable law to the validity of child marriages contracted abroad will be analyzed. An evaluation will be reviewed to decipher whether they can be considered as the next steps to be adopted by Turkish law.
\end{abstract}

\section{Keywords}

Child marriage, Temporary protection, Refugees, Syrians, Marriage age, Applicable law, Personal status, Public policy, The best interests of the child, The right to respect for family life

Sorumlu Yazar: Ayşe Elif Ulusu Karataş (Dr. Öğr. Üyesi), İstanbul Üniversitesi, Hukuk Fakültesi, Milletlerarası Özel Hukuk Anabilim Dalı, İstanbul, Türkiye. E-posta: eulusu@istanbul.edu.tr ORCID: 0000-0003-2221-5339

Atrf: Ulusu Karataş AE, "Geçici Koruma Altındaki Suriye Vatandaşlarının Çocuk Yaşta Evliliklerinin Mukayeseli Hukuka ve Türk Hukukuna Göre Geçerliliği" (2020) 78(1) İstanbul Hukuk Mecmuası 21. https://doi.org/10.26650/mecmua.2020.78.1.0002 


\section{Extended Summary}

The recent influx of immigrants from Syria has led to an increase in child marriage practices across Turkey as in many other European countries. Turkey, being a party to the international conventions and a member of the Council of Europe, is under the obligation to take all measures to prevent and eliminate child marriage practices across Turkey, regardless of the nationality of the children in its country.

Among various aspects, this article focuses on the legal aspects of child marriages contracted by Syrians under temporary protection in Turkey. In this context, the legal challenges regarding the determination of applicable law to the validity of child marriages concluded in Turkey or abroad by Syrians will be tried to be resolved under international private law rules in Turkey. Also, the legislative measures recently adopted under Swiss, Dutch and German laws to prevent the recognition of child marriages will be analyzed to make proposals in Turkish law.

Due to the qualification of the marriage-age as an issue related to the marriage capacity under Turkish law (lex fori), applicable law to the marriage-age is the national laws of each spouse at the moment of marriage (TrIPL ${ }^{1}$ Art 13). In the application of this provision to Syrians under temporary protection, it should be clarified first whether TrIPL Art 4/1(a) is applicable to them in the determination of their national law. Art 4/1(a) which is similar to the 1951 Refugee Convention Art 12 states that; regarding the legal actions concluded by refugees and stateless persons in Turkey, the law of the country of domicile or the law of the country of habitual residence or, law of the country where they are located at the beginning of the proceedings shall be applied instead of their national laws. The debate here is, whether the term refugee in this provision includes the temporary protection status or not. This article suggests that, Art 4/1(a) should be interpreted to include temporary protection status since the parliamentary report has put forward the ratio legis of the provision as regulating the legal actions of all de-facto stateless persons who cannot benefit from the diplomatic protection of the country which they are citizens for any reasons during their stay in Turkey ${ }^{2}$.

In this regard, the marriages concluded in Turkey by Syrians under temporary protection shall be governed by Turkish law as the law of their country-of-residence. In Turkish law, the marriage age is 17 , but if a person does not reach the majority (18 years-old), it is only allowed with the permission of a legal representative. However, under exceptional circumstances, it may be allowed by a judge permit at the-age-of

\footnotetext{
Türk Milletlerarası Özel Hukuk ve Usul Hukuku Hakkında Kanun (Turkish International Private and Procedural Law Code), Kanun Numarasi: 5718, Kabul Tarihi: 27.11.2007, RG 12.12.2007-26728. Latest version see at https://www. mevzuat.gov.tr/MevzuatMetin/1.5.5718.pdf.

2 Bkz MÖHUK Tasarısı Madde Gerekçeleri, Madde 4, Başbakanlık Kanunlar ve Kararlar Genel Müdürlüğü, 7/7/2006 $<$ https://www2.tbmmgov.tr/d23/1/1-0337.pdf> Erişim Tarihi 08 February 2020.
} 
$16\left(\operatorname{TrCC}^{3}\right.$ Art 124/2). According to the Turkish Supreme Court decisions marriages which are contracted under the exceptional marriage age of 16 are null and void 4 However marriage-age in the marriages concluded abroad shall be governed by Syrian law as the "national law" of the Syrian spouse(s), since Art 4/1(a) is applicable only to the legal actions concluded in Turkey. The provisions of the Syrian Law of Personal Status 1953, allows 13-years-old (and even younger if they're already pregnant) girls to marry (Art 18).

As the exceptional marriage age is 16 according to Turkish law, in cases where at the time of recognition the Syrian spouse is under 16 years old, it shall be determined whether the recognition of such marriages by application of the rules of Syrian law would be manifestly contrary to Turkish public policy under TrIPL Art 5 and if so which law should be applied to the consequences of such an invalid marriage. This article suggests that; it is not possible and appropriate to draw a minimum age limit in child marriages, since the application of public policy exception requires an individual case-by-case determination regarding the circumstances of each case and a manifest violation of Turkish public policy under TrIPL Art 5. Moreover, in child disputes, the best interests of the child also shall be taken into account in all circumstances. Hence, the refusal of the recognition of a child marriage based on the public policy exception should not cause greater harm for the child victim, especially regarding the effects of the marriage. In this respect, in cases where at the time of recognition one of the Syrian spouses is under the-age-of 16, public policy exception should not lead to an automatic non-recognition of the marriage and the assessment should be done in a manner to strike a fair-balance between the values of Turkish society and the protection of the best interests of the child. However, it is also concluded that, as the sexual acts with children under the-age-of 15 are criminalized as sexual child abuse under $\mathrm{TrPC}^{5}$ Art 103/1(a), the application of Syrian law which allows marriages under the-age-of 15 may very likely be found manifestly contrary to Turkish public policy and such marriages where at the time of recognition one of the Syrian spouses is under 15-years old may not be recognized under Turkish law. In cases where a manifest violation of Turkish public policy has been decided, it is suggested under TrIPL Art 5, the consideration must firstly be put on Syrian law (lex causae) and if no solution can be found it shall be referred to Turkish law (lex fori). Therefore, regarding the law applicable to the effects and consequences of non-recognised child marriages, Syrian law rules should be applied; according to which, the marriages contracted under the minimum marriage-age shall be found voidable but not void.

Türk Medeni Kanunu (Turkish Civil Code), Kanun Numarası: 4721, Kabul Tarihi: 22.11.2001, RG 08.12.2001-24607. Latest version see at <https://www.mevzuat.gov.tr/MevzuatMetin/1.5.4721.pdf> Erişim Tarihi 11 February 2020.

4 Yargitay 2 HD, 4235/7649, 03.05.2011; Yargitay 2 HD, 4315/5370, 14.04.2003; Yargitay 2 HD, 6049/14441, 30.10.2006. See Ömer Uğur Gençcan, Aile Mahkemesi Davaları (2. Bası, Yetkin Yayınları 2016) 93.

Türk Ceza Kanunu (Turkish Penal Code), Kanun Numaras1: 5237, Kabul Tarihi: 26.09.2001, RG 12.10.2004-25611. Latest version see at $<$ https://www.mevzuat.gov.tr/MevzuatMetin/1.5.5237.pdf> Erişim Tarihi 11 February 2020. 
It is also concluded that, under Art 8 and Art 12 of EHCR and ECtHR resolutions, any non-recognition of a child marriage does not constitute a violation of "the right to respect for family life". However, since de-facto relationships which considered as "family life" are also protected under EHCR Art 8; it is underlined that the protection measures taken for the minor spouse upon the non-recognition of a child marriage by Turkish courts must be in accordance with the principle of proportionality to not constitute a violation of EHCR Art 8.

Lastly, legislative measures which aim at implementing the lex loci celebrationis instead of the "national laws of each spouse" (Swiss IPRG Art 44, 45a; Dutch BW Art 10:28-10:32:c; German EGBGB Art 13/3) as the law applicable to the marriage capacity and terms of marriage concluded in the country and eliminating the public policy exception by bringing a general prohibition for the recognition of child marriages contracted abroad (IPRG Art 45a; $B W$ Art 10:32:c; EGBGB Art 13/3) adopted in Swiss, Dutch and German conflict-of-law rules in the context of preventing and combating child marriages are not found to be consistent with the principle of the protection of the best interests of the child in international private law. It is suggested that the best tool at preventing and combating the child marriage in international private law is the public policy exception which enables to strike a fair-balance between the values of the country and the best interest of the child by a case-by-case analysis. 


\section{Geçici Koruma Altındaki Suriye Vatandaşlarının Çocuk Yaşta Evliliklerinin Mukayeseli Hukuka ve Türk Hukukuna Göre Geçerliliği}

\section{Giriş}

Suriye krizinin patlamasıyla birlikte, Suriye Arap Cumhuriyeti'nden gelen zorunlu göç akını, başta Türkiye olmak üzere, diğer Avrupa ülkeleri bakımından da, özellikle kız çocuklarının maruz kaldıkları “çocuk yaşta evlilikler” problemini beraberinde getirmiştir. Türkiye’de, 4721 sayılı Türk Medeni Kanunu' (TMK) ve 5237 sayılı Türk Ceza Kanunu'nda² (TCK) gerçekleştirilen değişiklikler ve alınan önlemlerle azalma eğilimine girmiş olan “çocuk yaşta evlilik” sorunu, Suriyeli göç akını ile birlikte tekrar yükselişe geçmiştir.

UNICEF' in 2017 yılına ait verilerine göre; Türkiye'de 20-24 yaş arası genç kadın nüfusunda, 18 yaş altı evlilik veya evlilik dışı yaşam birlikteliği oranı \% 15, 15 yaş altı yaşam birlikteliği oranı ise \% 1 olarak tespit edilmiştir ${ }^{3}$. Türkiye İstatistik Kurumu'nun (TÜİK) 2016 yılı verilerine göre; 2016 yılında gerçekleştirilen evliliklerin \%17,9’u 18 yaş altında gerçekleştirilmiştir. Bu oran neredeyse her 5 evlilikten birinin çocuk yaşta evlilik olduğu anlamına gelmektedir. Ayrıca, yine 2016 TÜİK verilerine göre, 18 yaş altında evlilik oranı kadınlarda \%28,2 iken; erkeklerde \%5,6 oranındadır ${ }^{4}$. 2018 yılı TÜİK verilerine göre ise, 2018 yılında Türkiye'de 15-17 yaş grubunda 11 bin 636 çocuk anne olurken; 167 kız çocuğunun 15 yaşından küçük anne olduğu belirlenmiştir ${ }^{5}$. 16-17 yaş grubunda evlenen kız çocuklarının oranı ise, \% 3,8 olarak açıklanmıştır ${ }^{6}$. Türkiye'de 18 yaş altı evliliklerin çoğunluğu ve asgari evlenme yaşı olan 16 yaş altı birlikteliklerin hiçbiri resmi evlilik olarak gerçekleşmediğinden ve resmi kayıt altına alınamadığından; UNICEF ve TÜİK'in verilerindeki bu oranlar gerçek durumu yansitamamaktadır. Ancak bu verilere göre dahi, Türkiye, diğer Avrupa devletlerine nazaran, çocuk yaşta evlilik oranı en yüksek ülkedir ${ }^{7}$.

Türkiye'nin çocuk yaşta evlilik oranı verilerinin bu kadar yüksek olmasının bir sebebi de, yukarıda belirttiğimiz üzere, Suriyeli göç akınıdır. Suriyeli kız çocukları, ya Suriye'den evlilik yapmış olarak gelmekte veya Türkiye’ye giriş yaptıktan sonra evlilik yapmaktadır. Suriyeliler Türkiye'ye kitle halinde giriş yaptıklarından ve medeni halleri beyan esasına dayandığından, Suriye’den evlenmiş olarak 18 yaş altı kaç kız

Türk Medeni Kanunu, Kanun Numarası: 4721, Kabul Tarihi: 22.11.2001, RG 08.12.2001/24607.

Türk Ceza Kanunu, Kanun Numaras1: 5237, Kabul Tarihi: 26.09.2001, RG 12.10.2004-25611.

UNICEF Data, 'Child Marriage' (2018)<https://data.unicef.org/topic/child-protection/child-marriage/> Erişim Tarihi 11 February 2020 .

4 TÜIK, Republic of Turkey Ministry of Family and Social Policy, 'Family Structure Survey' (2016)<http://www.turkstat. gov.tr/PreHaberBultenleri.do?id=21869> Erişim Tarihi 11 February 2020.

Servet Yanatma, 'Türkiye'de 2018'de 11 binden fazla çocuk doğum yapt1; 167 'si 15 yaşından küçük' Euronews (5 July 2019) <https://tr.euronews.com/2019/07/05/turkiye-de-2018-de-11-binden-fazla-cocuk-dogum-yapti-167-si-15-yasindankucuk-tuik-nufus $>$ Erişim Tarihi 11 February 2020.

TÜiK, ‘İstatistiklerde Çocuk’ (2018) <http://tuik.gov.tr/PreHaberBultenleri.do?id=30708> Erişim Tarihi 11 February 2020.

Karşılaştırmak için bkz UNICEF Data, (n 3). 
çocuğunun geldiğine ilişkin sağlıklı bir veriye ulaşılamamaktadır. Keza Suriyelilerin, Türkiye'ye girdikten sonra, Türk hukukundaki evlenme yaşına ulaşmadan yaptıkları çocuk yaşta evlilikler bakımından da, resmi kayda girmediğinden, sağlıklı bir istatistik verilememektedir. Bu nedenlerle, Türkiye' de geçici koruma statüsü altındaki kız çocukları arasında evlenme yaşına ve oranına ilişkin veriler çeşitli kurumlarca yürütülen saha çalışmalarına dayanmaktadır.

Birleşmiş Milletler Mülteciler Yüksek Komiserliği (BMMYK/UNHCR) tarafindan, 2014 yılında Türkiye'deki iltica kamplarında gerçekleştirilen, kadın, erkek, kız ve erkek çocuklardan oluşan 200 kişilik bir odak grup çalışmasında, Suriye'de çocuk yaşta evliliklerin genellikle kırsal kesimde 13 yaşa kadar düştüğü, şehirlerde ise en erken 15 veya 16 yaşlarında olduğu; geçici barınma merkezlerinde ise bu yaşın 13'e kadar düştüğü tespit edilmiştir. Araştırmada katılımcılar, finansal zorluklar ve güvenlik sağlama gerekçeleri ile kız çocuklarını çocuk yaşta evlendirdiklerini ifade etmişlerdir ${ }^{8}$ BM Kadın Birimi tarafından 2018 yılında Türkiye' de gerçekleştirilen ve 15 yaş ve üzeri 1290 Suriyeli kadın ve kız çocuğu ile yapılan görüşmelere dayanan analizde; 18 yaş altı evlilik oranının $\% 50,3 ; 15$ yaş altı evlilik oranının ise $\% 23$ olduğu tespit edilmiştir. Ayrıca, okula gitme oranı, 12-14 yaş arası kız çocuklarında \% 60 iken; 15-17 yaş arasında bu oran \%23'e düşmekte ve bu düşüşün başlıca sebebi olarak çocuk yaşta evlilik gösterilmektedir ${ }^{9}$. Dolayısıyla, iltica, kız çocukları bakımından çocuk yaşta evlilik oranını yükseltmekte ve iltica edenler de Türkiye' deki çocuk yaşta evlilik oranını yükseltmektedir ${ }^{10}$.

BMMYK'nın, Türkiye’ye yönelik Suriyeli sığınmacı akınına ilişkin alınması gereken önlemlere ilişkin olarak hazırladığı 2014-2015 yıllarına ilişkin değerlendirme raporunda da; Türkiye'de geçici koruma statüsü altında bulunan Suriyeli kız çocuklarının maruz kaldıkları en önemli tehlikenin çocuk yaşta evlilik olduğuna, çocuk yaşta evliliklere ilişkin herhangi bir veri bulunmadığına ve iltica koşulları sebebiyle Türkiye'de çocuk yaşta evlilik riskinin Suriye'de olduklarından daha fazla olduğuna dikkat çekilmiştir ${ }^{11}$.

Bu oranlar Türkiye'nin tekrar yükselişe geçen ve özellikle kız çocuklarını etkileyen çocuk yaşta evlilik sorunu ile karşı karşıya olduğunu göstermektedir. Bu

\footnotetext{
CARE International UK, 'To Protect Her Honour-Child marriage in emergiencies-the fatal confusion between protecting girls and sexual violence' (2015) $7<\mathrm{https}$ ://insights.careinternational.org.uk/media/k2/attachments/CARE_Child-marriagein-emergencies_2015.pdf> Erişim Tarihi 11 February 2020.

9 UN WOMEN, 'Türkiye'de Geçici Koruma Altındaki Suriyeli Kadın ve Kız Çocukların İhtiyaç Analizi' (2018) Grafik 8 $<$ http://sgdd.org.tr/wp-content/uploads/2018/08/The_Needs_Assessment_TR_WEB.pdf> Erişim Tarihi 11 February 2020.

10 Ürdün'de UNICEF tarafından 2014 yılında yapılan bir araştırmada; 2011 yılında Suriyeli sığınmacılar arasında 15-17 yaş arası kız çocuklarının dâhil oldukları kayıtlı evlilik oranı \%11 iken; 2013 y1lında bu oranın \%25'e ve 2014 yılının ilk çeyreğinde ise \%32'ye yükseldiği kaydedilmiştir. Bkz UNICEF, ‘A Study on Early Marriage in Jordan' (2014) 8, 22-23 $<$ https://reliefweb.int/sites/reliefweb.int/files/resources/UNICEFJordan_EarlyMarriageStudy2014.pdf > Erişim Tarihi 11 February 2020.

11 UNHCR Evaluation Service, 'Evaluation of UNHCR's Emergency Response to the influx of Syrian Refugees into Turkey' (2016) 52-55<https://www.unhcr.org/58a6bbca7.pdf> Erişim Tarihi 11 February 2020.
} 
çalışmada, Türkiye'nin gelecek 20 yılını sosyolojik olarak etkilemesi muhtemel, Suriyelilerce gerçekleştirilen çocuk yaşta evliliklerin hukuki boyutu ele alınacaktır. Bu kapsamda öncelikle, çocuk yaşta evlilik kavramı ve sonuçları ile çocuk yaşta evlilik uygulamasının uluslararası belgelerdeki yeri ele alınacak ve ardından, uluslararası koruma sağlayan Avrupa ülkelerinde çocuk yaşta evlilik uygulamalarının önlenmesine yönelik getirilen mevzuat değişiklikleri incelenecektir. Çalışmamızın üçüncü bölümünde ise, Suriyelilerin Türkiye'ye gelmeden önce veya Türkiye'ye geldikten sonra gerçekleştirdikleri çocuk yaşta evliliklerin Türk hukukuna göre geçerliliği, başka bir ifadeyle, bu evliliklerin Türk hukukunda tanınıp tanınmayacağı meselesi, Türk milletlerarası özel hukuk kuralları çerçevesinde, özellikle geçici koruma altındaki Suriyelilerin milli hukukunun tespiti, Türk kamu düzenine aykırılık ve aile hayatına saygı hakkının korunması boyutlarıyla ele alınacak ve çözüm önerileri sunulacaktır.

\section{I. Çocuk Yaşta Evlilik ve Uluslararası Hukuki Çerçeve}

\section{A. Çocuk Yaşta Evlilik Kavramı ve Sonuçları}

"Çocuk yaşta evlilik" (child marriage); 18 yaşını doldurmamış bir çocuk ile bir başka çocuk veya yetişkin arasındaki resmi evlilik veya gayri resmi birliktelikleri ifade etmektedir"12. "Çocuk yaşta evlilik"leri ifade etmek üzere; "küçük yaşta evlilik", "erken yaşta evlilik" veya "zorla evlilik" ifadeleri de kullanılmaktadır ${ }^{13}$.

Birleşmiş Milletler ve Avrupa Konseyi tarafından; 18 yaşını doldurmamış bir çocuğun, yaşı gereği, evleneceği kişiye veya evliliğinin zamanlamasına ilişkin olarak, "serbest, bağımsız ve tam bir rıza" vermeye ehil olmadığı kabul edildiğinden,

12 Bkz UN CEDAW/CRC, 'Joint General Comment No 31 of the CEDAW / No 18 of the CRC on the Rights of the Child on harmful practices', (2014) UN-Doc CEDAW/C/GC/31-CRC/C/GC/18 para 20; PACE, 'Resolution on Forced Marriages and Child Marriages' (2005) Resolution No 1468 para 7; PACE, 'Resolution on Forced Marriage in Europe' (2018) Resolution No 2233 para 3. Türkiye'nin de taraf olduğu, 1989 tarihli Çocuk Haklarına Dair Sözleşme'nin 1. maddesi uyarınca; çocuğun tabi olduğu hukuka göre daha erken yaşta reşit olma hali hariç, 18 yaşına kadar her insan çocuk sayılır. 5395 sayılı Çocuk Koruma Kanunu m 3/1(a) uyarınca ise "çocuk"; daha erken yaşta ergin olsa bile, 18 yaşını doldurmamış kişidir. Çocuk Koruma Kanunu, Kanun Numaras1: 5395, Kabul Tarihi: 03.07.2005, RG 15.07.2005/25876.

134721 sayılı Türk Medeni Kanunu’nda; “çocuk” kavramı tanımlanmamıştır. Türk Medeni Kanunu’nda, fiil ehliyetinin şartlarının düzenlendiği TMK m 11 uyarınca, erginlik yaşı olan 18 yaşını doldurmamış kişiler için "küçük" ifadesi kullanılmaktadır. Evlenme ehliyetinin düzenlendiği TMK m 126'da da küçüğün evlenmesinden bahsedilmektedir. Bu nedenle, Türk hukuk literatüründe, 18 yaşını doldurmamış çocukların evlilikleri için genellikle, "küçük yaşta evlilik" ifadesi tercih edilmektedir. Bkz Dilşad Keskin, 'Küçük Yaşta Evlenmenin Müeyyidesi' (2011) 15(4) GÜHFD 65, 70-71. İsviçre Medeni Kanunu'nda (ZGB), evlenmenin mutlak butlan sebeplerinin düzenlendiği Art 105/6' da da, 18 yaşını doldurmamış eş bakımından, eşlerden birinin "küçük" olması ifadesi kullanılmaktadır. Bunun yanında; küçük yaşta evliliğin mutlak butlan sebebi olarak İsviçre Medeni Kanunu'na girmesini sağlayan ve 1 Temmuz 2013 tarihinde yürürlüğe giren “15 Haziran 2012 tarihli Zorla Evliliklere Karşı Tedbirler Hakkından Federal Kanun” (Bundesgesetz über Massnahmen gegen Zwangsheiraten) uyarınca, 18 yaş altı "küçük yaşta evlilikler", "zorla evlilik" türü olarak nitelendirilmiştir. Hollanda Medeni Kanunu'nda (Burgerlijk Wetboek) evlilik yaşı ile ilgili değişiklikler getiren ve 5 Aralık 2015 tarihinde yürürlüğe giren "7 Ekim 2015 tarihli Zorla Evlilikle Mücadele Kanunu" (de Wet tegengaan huwelijksdwang) da, 18 yaş altı evlilikleri, "zorla evlilik" türü olarak nitelendirmiştir. Alman Medeni Kanunu'nda (BGB) da, evlenmenin iptal edilebilirlik sebeplerinin düzenlendiği §1314'te, 18 yaşını doldurmamış eş bakımından, eşlerden birinin "küçük" olması ifadesi kullanılmaktadır. Bunun yanında; Alman Medeni Kanunu'nda evlilik yaşı ile ilgili değişiklikler getiren ve 22 Temmuz 2017 tarihinde yürürlüğe giren "17 Temmuz 2017 tarihli Çocuk Evliliklerle Mücadele Kanunu"nda (Gesetz zur Bekämpfung von Kinderehen) "çocuk yaşta evlilikler" ifadesi tercih edilmiştir. 
"çocuk yaşta evlilikler", "zorla evliliğin” bir türü olarak nitelendirilmektedir"14. Gerçekten de pek çok kız çocuğu, evlenmenin anlam ve amacını anlayabilecek, evlenmeye bağlı yükümlülük ve ödevleri kavrayabilecek yeteneğe sahip olmaksızın, geleceğine dair diğer seçeneklerinden habersiz, çocuk yaşta evliliği kaderi sayarak, kendi isteğiyle evlenmeyi kabul etmiş olabilir. Ancak bu istek, hukuki anlamda serbest, bağımsız ve bilinçli bir rıza açıklaması olarak sayılmamalıdır.

UNICEF'in araştırmalarına göre, dünya genelinde çocuk yaşta evlilikuygulamasına, kız çocukları, erkek çocuklarından daha fazla maruz kalmaktadır. UNICEF'in Mart 2018 verilerine göre; 20-24 yaş arası dünya genç kadın nüfusunun \%21 ’i, 18 yaşından önce; \%5'i ise, 15 yaşından önce evlenmek veya gayri resmi birliktelik yaşamak durumunda kalmış kadınlardan oluşmaktadır. Dünya genelinde, 15 ila 19 yaş arası, her altı ergen kız çocuğundan biri, resmi veya gayri resmi birliktelik yaşamaktadır. Halen, her yı1, 12 milyon kız çocuğu, 18 yaşını doldurmadan evlendirilmektedir. Bu oranlar, 650 milyon kız çocuğu ve kadına tekabül etmektedir ${ }^{15}$. Bu veriler göstermektedir ki; "çocuk yaşta evlilik” uygulaması, kız çocuklarının, erkek çocuklarına oranla çok daha fazla maruz kaldığı, kökleşmiş cinsiyet eşitsizliğinin sonuçlarından biridir.

Kız çocuklarını, çocuk yaşta resmi veya gayri resmi birliktelik yaşama riskine maruz bırakan ve aslında birbirini de tetikleyen pek çok sebep bulunmaktadır. Yoksulluk, başlık parası, evliliğin korunma sağlayacağına olan inanç, aile şerefi, namus, sosyal çevre, çocuk yaşta evlilikleri hoş gören gelenek-görenekler ve dini inançlar ile yetersiz kanuni düzenlemeler başlıca sebepler olarak gösterilmektedir ${ }^{16}$.

Çocuk yaşta evlilikler, kız çocuklarının yaşamlarını, sağlıklarını ve gelecek beklentilerini ciddi anlamda tehdit etmekte ve bu bakımından toplum sağlığ ve refahı açısından da çok ciddi zararlara sebebiyet vermektedir. 18 yaşından önce evlenmek durumunda kalmış kız çocukları arasında, aile içi şiddete maruz kalma ve okula devam etmeme oranı, evlenmemiş yaşıtlarına nazaran daha yüksektir ${ }^{17}$. Çocuk yaşta evlilik yapan kız çocukları, genellikle henüz ergenlik dönemindeyken hamile kaldıklarından, hamilelik ve doğum sırasında sağlık problemleri yaşama ve ölüm riskleri artmaktadır. Nitekim çocuk yaşta evliliklerin yaygın olduğu ülkelerde, 15-19 yaş arası ergen kız çocuğu ölümlerinin ana sebepleri erken yaşta hamilelik ve doğumda yaşanan sorunlar olarak gösterilmektedir ${ }^{18}$. Çocuk yaşta evlilik uygulaması, kız çocuklarının, aileleri ve arkadaşlarından ayrı kalmalarına ve yalnızlaşmalarına

\footnotetext{
14 CEDAW/CRC 'Joint General Comment' (n 12) para 20; PACE ‘Resolution on Forced Marriage in Europe' (n 12) para 3.

15 UNICEF Data (n 3).

16 UNICEF Data (n 3).; UNFPA, 'Marrying Too Young End Child Marriage' (2012) $11<$ https://www.unfpa.org/sites/default/ files/pub-pdf/MarryingTooYoung.pdf> Erişim Tarihi 11 February 2020; ECPAT International, 'Preventing and Eliminating Child, Early and Forced Marriage: challenges, achievements, best practices \& implementation gaps', (2013)<https://www. ohchr.org/_layouts/15/WopiFrame.aspx?sourcedoc=\%2FDocuments\%2FIssues\%2FWomen\%2FWRGS\%2FForcedMarria ge $\% 2$ FNGO\%2FECPATInternational\%2Edoc\&action=view> Erişim Tarihi 11 February 2020.

17 UNFPA (n 16) 11

18 UNFPA (n 16) 11.
} 
da sebebiyet verebilmekte ve bu suretle kız çocuklarının psikolojik gelişimini de olumsuz yönde etkileyebilmektedir. Dahası, gayri resmi birliktelik içerisinde olan kız çocukları; miras ve vatandaşlık kazanma haklarının tanınmaması ve toplumsal dışlanma gibi sebeplerle, resmi birliktelik içerisindeki kız çocuklarından hukuken ve sosyolojik olarak daha korunmasız durumda kalmaktadır. Tüm bu olumsuz neticeler, çocuk yaşta evlendirilmiş kız çocuklarını, evlenmemiş yaşıtlarına nazaran daha kötü ekonomik ve sağlık şartlarına maruz bırakmakta ve bu şartlar, onların çocuklarının da yaşam standartlarına sirayet etmektedir. Bu sebeplerle, çocuk yaşta evliliklerin, kız çocuklarının sağlığı, geleceği ve aileleri üzerindeki bu olumsuz etkileri, toplumun kalkınması ve refahı önünde de ciddi bir engel teşkil etmektedir ${ }^{19}$.

"Çocuk yaşta evlilik" uygulaması; bir kişinin evlenme hususunda serbest, bağımsız ve tam rizasının var olması gerekmesi bakımından, bir "insan hakları" meselesi olduğu gibi; aynı zamanda bir kamu sağlığı meselesidir. Ayrıca çocuk yaşta evlilikler, kız çocuklarının erkek çocuklarına nazaran daha fazla maruz kalması sebebiyle, bir "toplumsal cinsiyete dayalı şiddet" (gender-based violence) türü olduğu gibi; kadın ve çocuk hakları bakımından da bir "zararlı uygulama" (harmful practice) çeşididir" $\mathrm{Bu}$ itibarla, çocuk yaşta evlilik uygulaması; temel insan hakları, kadın hakları ve çocuk hakları ile ilgili pek çok milletlerarası sözleşmenin, doğrudan veya dolaylı olarak kapsamına girmekte ve bir ihlal sebebi olarak değerlendirilmektedir.

\section{B. Çocuk Yaşta Evliliği Yasaklayan Milletlerarası ve Bölgesel Belgeler}

Çocuk yaşta evlilik uygulaması, temel insan hakları metinlerinden olan 1948 tarihli "BM İnsan Hakları Evrensel Beyannamesi"nin (UDHR) ${ }^{21}$ 16. maddesinin 2. fikrası uyarınca, "evlenme akdi ancak müstakbel eşlerin serbest ve tam rizası ile yapılır" hükmü kapsamında bir temel insan hakkı ihlali olarak değerlendirilmektedir ${ }^{22}$.

Çocuk yaşta evlilik uygulamasını açıkça yasaklayan tek evrensel insan hakları sözleşmesi, Türkiye'nin de 1985 yılından beri taraf olduğu, 1979 tarihli "Kadınlara Karşı Her Türlü Ayrımcılığın Önlenmesi Sözleşmesi”dir (CEDAW) ${ }^{23}$. Sözleşme'nin 16. maddesinin 2. fikrası; “Çocuğun erken yaşta nişanlanması veya evlenmesinin hiçbir kanuni etkisi olmayacak ve evlenme asgari yaşının belirlenmesi

19 UNICEF Data (n 3); UNFPA (n 16) 11-12.

20 UN Women, 'Inter-Agency Assessment: Gender-Based Violence and Child Protection Among Syrian Refugees in Jordan with a Focus on Early Marriage' (2013) 29 <https://data2.unhcr.org/ar/documents/download/39522> Erişim Tarihi 11 February 2020; UNICEF Data (n 3); ECPAT International (n 16) 10; CEDAW/CRC 'Joint General Comment' (n 12) para 17; PACE ‘Resolution on Forced Marriages and Child Marriages 2005' (n 12) para 1.

21 The Universal Declaration of Human Rights (UDHR), UN General Assembly Resolution 217 A, Paris 10 December 1948.

22 PACE 'Resolution on Forced Marriages and Child Marriages 2005' (n 12) para 6; UN General Assembly Resolution 843 (IX) of 17 December 1954, 'Status of Women in Private Law: Customs, Ancient Laws and Practices Affecting The Human Dignity of Women' <https://documents-dds-ny.un.org/doc/RESOLUTION/GEN/NR0/095/78/IMG/NR009578. pdf?OpenElement> Erişim Tarihi 11 February 2020; ECPAT International (n 16) 2; UNFPA (n 16) s. 10.

23 UNHCR Convention on the Elimination of All Forms of Discrimination against Woman, New York, 18 December 1979 (CEDAW). RG 14.10.1985/18898. 
ve evlenmelerin resmi sicile kaydının mecburi olması için yasama dahil gerekli tüm önlemler alınacaktır" hükmünü ihtiva etmektedir. Sözleşme'de asgari evlenme yaşı belirtilmemiştir. Buna karşılık; Sözleşme’nin İzleme Komitesi, taraf devletlere, erkek ve kadınlar için 18 yaşı, asgari evlenme yaşı olarak kanunlaştırmaları konusunda çağrıda bulunmuştur ${ }^{24}$. Ayrıca yine 16. maddenin 1. fikrasında; kadınların evlenmede erkeklerle eşit hakka sahip olmasının ve özgür olarak eş seçme ve "serbest ve tam rıza" ile evlenme haklarının taraf devletlerce sağlanacağı hüküm altına alınmıştır ${ }^{25}$.

Çocuk yaşta evliliklerin ortadan kaldırılması ile ilgili taraf devletlere yükümlülükler getiren bir diğer önemli milletlerarası sözleşme ise, Türkiye’nin de 1995 yılından beri taraf olduğu, 1989 tarihli “Çocuk Haklarına Dair Sözleşme”dir $(\mathrm{CRC})^{26}$. Her ne kadar Sözleşme' de açıkça “evlilik”ten bahsedilmese de; çocuk yaşta evlilik uygulaması, Sözleşme’de yer alan diğer çocuk hakları ile ilintilidir. Çocuk yaşta evlilik uygulaması, Çocuk Hakları Sözleşmesi'nin 24. maddesinin 3. fikrası uyarınca, "çocukların sağlığı için zararlı geleneksel uygulamaların kaldırılması" yükümlülüğü kapsamında değerlendirilmekte ve zararlı bir uygulama olarak kabul edilmektedir ${ }^{27}$. Bu hükmün yanı sıra; CRC m 13/1 uyarınca, "çocuğun düşüncesini serbestçe açıklama hakkı" ve CRC m 19/1 uyarınca, "çocuğun her türlü istismar ve kötü muameleden korunması hakkı" da, "çocuk yaşta evlilik uygulaması" ile ilintili hak ve yükümlülüklerdir.

Türkiye'nin 2012 yılından beri taraf olduğu, 2011 tarihli "Kadınlara Yönelik Şiddet ve Aile İçi Şiddetin Önlenmesi ve Bunlarla Mücadeleye İlişkin Avrupa Konseyi Sözleşmesi” (İstanbul Sözleşmesi) ${ }^{28}$ de; “zorla evlendirme”yi bir kadına karşı şiddet türü olarak nitelendirilerek Sözleşme kapsamına alınmıştır. Sözleşme'nin 37. maddesinde; taraf devletlerin, zorla evlendirmelerin cezalandirılmasinı temin etmek üzere gerekli yasal ve diğer tedbirleri alacakları hüküm altına alınmıştır. Ayrıca Sözleşme'nin 32. maddesinde; taraf devletlere, zorla gerçekleştirilen evliliklerin, mağdura herhangi bir parasal veya idari yük getirmeksizin, geçersiz ve hükümsüz k1lınabilmesini veya sona erdirilmesini temin edecek yasal ve diğer tedbirleri alma yükümlülüğü getirilmiştir. Her ne kadar Sözleşme açıkça “çocuk yaşta evlilikler”den bahsetmese de; Avrupa Konseyi Parlamenterler Meclisi’nin kararlarında “çocuk yaşta

24 UN CEDAW, ‘General Comment No 21: Equality in Marriage and Family Relations' (1994) UN-Doc A/39/38 para 36.

25 Bunların yanında; CEDAW 2. maddesi uyarınca, "kadınlara ayrımcılık oluşturan mevcut yasa, adet ve uygulamaları ortadan kaldırma"; 3. maddesi uyarınca, "kadının tam gelişmesi ve ilerlemesini sağlamak için, tüm alanlarda, erkeklerle eşit olarak insan hakları ve temel özgürlüklerden yararlanmalarını sağlama" ile 5. maddesi uyarınca, "her iki cinsten birinin aşağılığı veya üstünlüğü fikrine veya kadınla erkeğin kalıplaşmış rollerine dayanan ön yargıları, geleneksel ve diğer bütün uygulamaları ortadan kaldırma" yükümlülüğü de, çocuk yaşta evlilik uygulamasının ortadan kaldırılmasını kapsamına almaktadır.

26 Convention on the Rights of the Child (CRC). RG 27.01.1995/22184.

27 CEDAW/CRC ‘Joint General Comment' (n 12) para 14; ECPAT International (n 16) 3; UNFPA (n 16 ) 10.

28 Council of Europe Convention on Preventing and Combating Violence against Women and Domestic Violence, 12 April 2011. RG 08.03.2012/28227(Mükerrer). 
evlilikler" bir "zorla evlendirme" türü olarak kabul edildiğinden ${ }^{29}$, kanaatimizce, “çocuk yaşta evlilikler”in de İstanbul Sözleşmesi kapsamında değerlendirilmesi mümkün olmalıdır.

Yukarıda saydığımız milletlerarası belgeler yanında; Türkiye'nin 1964'ten beri taraf olduğu, 1956 tarihli "Kölelik, Köle Ticareti, Köleliğe Benzer Uygulama ve Geleneklerin Ortadan Kaldırılmasına Dair Ek Sözleşme"30 uyarınca; "bir kadının, reddetmek hakkı olmadan, anne ve babasina, vâsisine, ailesine veya diğer herhangi bir şahıs yahut topluluğa nakdî veya aynî bir ivaz mukabilinde evlendirilmesi va'adinde bulunulması veya evlendirilmesi" (m 1/(c)(i)) ve "bir çocuğun veya 18 yaşından aşağı temyiz kudretini haiz bir kimsenin gerek anne ve babast, yahut bunlardan biri, gerekse vârisi tarafindan, şahsını veya işini istismar maksadiyle bedel mukabilinde veya bedelsiz diğer bir şahsa devrine müsait olan herhangi bir uygulama ve gelenek" (m 1/(d)), "köleliğe benzer uygulama ve gelenekler" arasında sayılmış ve bu itibarla "çocuk yaşta evlilikler" Sözleşme uyarınca yasaklanmıştır.

Ayrıca, yine Türkiye'nin 1988'den beri taraf olduğu, 1984 tarihli “İşkenceye ve Diğer Zalimane, Gayriinsani veya Küçültücü Muamele veya Cezaya Karşı BM Sözleşmesi”’31 kapsamında; BM İnsan Hakları Yüksek Komiserliği’nin ve BM İnsan Hakları Konseyi'nin çeşitli raporlarında, çocuk yaşta evlilikler, gayriinsani ve küçülttücü muamele olarak nitelendirilmiş ve taraf devletlerin 18 yaştan önce evlenmeyi yasaklayan kanun ve düzenlemeler yapma ve çocuk yaşta evlilik uygulamasını önleme yükümlülüğünde olduklarının altı çizilmiştir ${ }^{32}$.

Bölgesel düzeyde bakıldığında da, Türkiye'nin kurucu üyesi olduğu Avrupa Konseyi Parlamenterler Meclisi'nin (AKPM), “çocuk yaşta evlilikler" ve "zorla evlilikler" ile ilgili, 2005 ve 2018 tarihli kararları mevcuttur ${ }^{33}$. Bu kararlarda; çocuk yaşta evliliklerin, bir insan hakkı ihlali ve aynı zamanda bir zorla evlendirme türü teşkil ettiği ifade edilerek; Konsey üyesi devletlerin iç hukuk mevzuatlarında, asgari evlenme yaşını kadın ve erkekler için 18 yaşa yükseltmeleri ve yabancı ülkede yapılan çocuk yaşta evlilikleri tanımalarını engelleyici, (mağdur tarafından başka türlü ileri sürülemeyecek evlenmenin sonuçlarına ilişkin hakların güvence altına alınabilmesi amacıyla, tanımanın, mağdurun üstün yararına olduğu haller hariç olmak üzere) değişiklikler yapmaları tavsiye edilmiştir ${ }^{34}$.

\footnotetext{
29 PACE 'Resolution on Forced Marriage in Europe 2018' (n 12) para 3.

30 Supplementary Convention on the Abolition of Slavery, the Slave Trade, and Institutions and Practices Similar to Slavery. RG. 06.01.1964/11599.

31 Convention against Torture and Other Cruel, Inhuman or Degrading Treatment or Punishment. RG. 10.08.1988/19895.

32 UN OHCHR, 'Preventing and Eliminating Child, Early and Forced Marriage' (2014) UN-Doc A/HRC/26/22 para 11-15; UN HRC, 'Report of the Special Rapporteur on Torture and Other Cruel, Inhuman or Degrading Treatment or Punishment' (2016) UN-Doc A/HRC/31/57 paras 63, 74/c.

33 PACE 'Resolution on Forced Marriages and Child Marriages 2005' (n 12); PACE 'Resolution on Forced Marriage in Europe 2018' (n 12).

34 PACE 'Resolution on Forced Marriages and Child Marriages 2005' (n 12) paras 1, 3, 14.
} 
Netice itibariyle, Türkiye, yukarıda açıkladığımız milletlerarası sözleşmelere ve Avrupa Konseyi'ne taraf bir devlet olması itibariyle, çocuk yaşta evlilik uygulamasını, ülkesinde bulunan çocukların milliyetine bakmaksızın önlemek ve ortadan kaldırmak için her türlü önlemi alma yükümlülüğü altındadır. $\mathrm{Bu}$ yükümlülüklerine aykırı davranması, insan hakları ihlali teşkil edecektir.

\section{Mukayeseli Hukukta Çocuk Yaşta Evliliklerinin Önlenmesine Yönelik Mevzuat Değişiklikleri}

Çocuk yaşta evlilik uygulamasını önlemeye ve yasaklamaya yönelik uluslararası belgeleri incelerken belirttiğimiz üzere; AKPM'nin 2005 tarihli Tavsiye Kararı'nda, Avrupa Konseyi üyesi devletlere, yabancı ülkede yapılan çocuk yaşta evliliklerin tanınmasını engelleyecek mevzuat değişiklikleri yapmaları tavsiye edilmiştir ${ }^{35}$. Ancak Avrupa devletlerinin iç hukuk düzenlemelerine bakıldığında, Suriye krizi sebebiyle Avrupa'ya iltica akınının yoğunlaştığı 2013 yılına kadar, söz konusu devletlerin, milletlerarası özel hukuk mevzuatlarında, yabancı ülkelerde yapılan evliliklerin geçerliliğine ilişkin olarak herhangi bir değişiklik yapmadıkları görülmektedir. 2013 yılından itibaren ise, çocuk yaşta evliliklerin Avrupa ülkelerinde artmaya başlaması üzerine, pek çok Avrupa devleti, gerek medeni hukuk gerekse milletlerarası özel hukuk mevzuatlarında, bu evlilikleri engellemeye ve geçersiz kılmaya yönelik değişiklikler yapmaya başlamıştır.

Aşağıda Türk hukuku gibi, Kıta Avrupası hukuk sistemini benimsemiş olan ve Suriye krizi sürecinde iltica akınının yoğunlaştığı, İsviçre, Hollanda ve Almanya'nın, iç hukuk mevzuatlarında, yabancı ülkede yapılan çocuk yaşta evliliklere yönelik değişiklikler incelenecektir.

\section{A. İsviçre Hukuku}

İsviçre'de, Hollanda ve Almanya'dan daha önce, çocukların korunmasını sağlamak ve çocuk yaşta evliliklerle mücadele etmek üzere; önce "19 Aralık 2008 tarihli Yetişkin Koruma, Kişi Hakları ve Çocuk Hakları Kanunu" (Schweizerisches Zivilgesetzbuch Erwachsenenschutz, Personenrecht und Kindesrecht) 36 ve daha sonra "15 Haziran 2012 tarihli Zorla Evliliklere Karşı Tedbirler Hakkında Federal Kanun" (Bundesgesetz über Massnahmen gegen Zwangsheiraten) kabul edilmiş ve bu Kanun 1 Temmuz 2013 tarihinde yürürlüğe girmiştir ${ }^{37}$.

\footnotetext{
PACE 'Resolution on Forced Marriages and Child Marriages 2005' (n 12) para 14.

36 Schweizerisches Zivilgesetzbuch (Erwachsenenschutz, Personenrecht und Kindesrecht) vom 19 Dezember 2008 (AS 2011 725) mit Wirkung seit 1 Januar 2013.

37 Bundesgesetz über Massnahmen gegen Zwangsheiraten vom 15 Juni 2012 (AS 2013 1035) in Kraft seit 1 Juli 2013.
} 
Kanunun isminden de anlaşılacağ 1 üzere, İsviçre kanun koyucusu, 18 yaşın altındakilerin gerçekleştirdikleri çocuk yaşta evlilikleri, bir "zorla evlilik" türü olarak nitelendirmiştir. Zorla Evliliklere Karş1 Tedbirler Hakkında Federal Kanun, başta İsviçre Medeni Kanunu (Schweizerisches Zivilgesetzbuch/ZGB) ${ }^{38}$ ve İsviçre Milletlerarası Özel Hukuk Kanunu (Bundesgesetz über das Internationale Privatrecht) IPRG) ${ }^{39}$ olmak üzere; İsviçre Yabancılar ve Entegrasyon Kanunu (Ausländergesetz/ AIG)40 ve İsviçre İltica Kanunu (Asylgesetz/AsylG)41 gibi pek çok kanunda, çocuk yaşta evliliklerin önlenmesine ve yabancı ülkede yapılanların tanınmamasına yönelik değişiklikler getirmiştir.

Bu kapsamda, İsviçre Medeni Kanunu'nda (ZGB); olağan evlenme yaşı olan 18 yaşın altındakilerin, yasal temsilci izniyle evlenmelerini mümkün kılan ZGB Art 94/2 hükmü yürürlükten kaldırılmıştır. Bununla bağlantılı olarak; "küçük olan eşin üstün menfaati evliliğin devamını gerektirmedikçe, eşlerden birinin 18 yaşından küçük olması" ve "eşlerden birinin tam ve serbest rizası olmaksızın evlenmesi" halleri, ZGB Art 105/5-6 uyarınca, birer "mutlak butlan" sebebi olarak kabul edilmiştir.

ZGB Art 105/6 uyarınca, eşlerden birinin küçük olması halinde, evlenmenin mutlak butlanla batıl olmasının tek istisnası, "evliliğin devamının kü̧̈üğ̈̈n üstün yararina olması” halidir. Söz konusu istisna hükmü; AKPM'nin, 2005 tarihli Tavsiye Kararı'nda, yabancı ülkede yapılan çocuk yaşta evliliklerin tanımamasının istisnası olarak ortaya koyduğu, "mağdur tarafindan başka türlü ileri sürülemeyecek evlenmenin sonuçlarına iliş̧in hakların güvence altına alınabilmesi amacıyla, tanımanın, mağdurun üstün yararına olduğu haller" kriterine de uygunluk taşımaktadir ${ }^{42}$.

İsviçre Milletlerarası Özel Hukuk Kanunu'nda (IPRG) yapılan değişikliklerden ilki ise, evlenmeye uygulanacak hukuka ilişkindir. Eski IPRG Art 44/2 uyarınca, "iki tarafin da yabancı olması halinde, İsviçre'de gerçekleştirilen evlenmenin ehliyet ve şartlarına, taraflardan her birinin milli hukukunun" uygulanacağına ilişkin hüküm kaldırılmış ve "İsviçre'de gerçekleştirilen evliliklerin İsviçre hukukuna tabi olduğu" kabul edilmiştir. Böylelikle, IPRG Art 44 uyarınca, İsviçre'de yapılan evlenmelerde, gerek evlenme ehliyet ve şartları gerekse evliliğin şekli İsviçre hukukuna tabi kılınmış ve İsviçre'de yapılan çocuk yaşta evliliklerin, ZGB Art 105/5-6 uyarınca mutlak butlanla batıl sayılması sağlanmıştır.

\footnotetext{
3 Schweizerisches Zivilgesetzbuch vom 10 Dezember 1907 (AS 24 233) in Kraft seit 1 Januar 1912.

39 Bundesgesetz über das Internationale Privatrecht vom 18 Dezember 1987 (AS 1988 1776) in Kraft seit 1 Januar 1989.

40 Bundesgesetz über die Ausländerinnen und Ausländer und über die Integration vom 16 Dezember 2005 (AS 2007 5437) in Kraft seit 1 Januar 2008.

41 Asylgesetz vom 26 Juni 1998 (AS 1999 2262) in Kraft seit 1 Oktober 1999.

42 PACE 'Resolution on Forced Marriages and Child Marriages 2005' (n 12) para 14.2.4.
} 
Ayrıca IPRG Art $45 a$ hükmünde yer alan "evlenme ile erginliğe” yönelik düzenleme kaldırılmış ${ }^{43}$ ve IPRG Art 45a' da “evlenmenin hükümsüzlüğü”ne ilişkin tamamen farklı yeni bir düzenleme getirilmiştir. Buna göre; evlenmenin hükümsüzlüğ̈̈ davalarında, eşlerden birinin Ísviçre'deki yerleşim yeri mahkemesi, bulunmadığ takdirde, Ísviçre'de evlenmenin yapıldiğg yer veya eşlerden birinin İsviçre'deki mutad mesken mahkemesinin yetkili olacă̆l ve davaya İsviçre hukukunun uygulanacă̆ hüküm altına alınmıştır. Böylelikle, yabancı ülkede yapılan çocuk yaşta evliliklerin hükümsüzlüğü davalarında İsviçre mahkemelerince İsviçre hukukunun (lex fori) uygulanacağı hüküm altına alınarak, yabancı ülkede yapılan çocuk yaşta evliliklerin de, "evliliğin devamının küçüğün üstün yararına olması" hali hariç, mutlak butlanla batıl sayılması sağlanmıştır.

\section{B. Hollanda Hukuku}

Hollanda'da Suriye'den itica edenlerin sayısının artması üzerine, çocuk yaşta evlenmiş olarak Hollanda'ya gelen kız çocuklarında artış yaşanmıştır. Hollanda İltica Servisi'nin verilerine göre, Temmuz 2014 ve Şubat 2016 arasında, en küçüğü 14 yaşında olmak üzere, yaklaşık 210 adet Suriyeli çocuk yaşta evlilik vakasının kaydedildiği bildirilmiştir ${ }^{44}$. Artan tepkiler üzerine, Hollanda, çocuk yaşta evliliklerle mücadele etmek üzere, 5 Aralık 2015 tarihinde yürürlüğe giren "7 Ekim 2015 tarihli Zorla Evlilikle Mücadele Kanunu"nu (de Wet tegengaan huwelijksdwang) ${ }^{45}$ kabul etmiştir. Hollanda kanun koyucusu da, İsviçre gibi, çocuk yaşta evlilikleri, bir zorla evlilik türü olarak nitelendirmiştir. Hollanda Zorla Evlilikle Mücadele Kanunu; Hollanda Medeni Kanunu'nun (Burgerlijk Wetboek/BW) ${ }^{46}$, kişiler ve aile hukukunu düzenleyen 1. Kitabı (BW Boek 1) ile milletlerarası özel hukuku düzenleyen 10. Kitabında (BW Boek 10), çocuk yaşta evliliklerin önlenmesine ve tanınmamasına ilişkin önemli değişiklikler getirmiştir.

Öncelikle, Hollanda Medeni Kanunu 1. Kitap’ta yer alan ve BW Art 1:31 uyarınca, kadın ve erkek için 18 olan evlenme yaşının altındaki küçüklerin, çeşitli şartlara bağlı olarak, evlenmelerine imkân veren tüm hükümler yürürlükten kaldırılmıştır ${ }^{47}$. Böylelikle, 18 yaşını doldurmamış olanlar tarafından yapılan tüm evlilikler, BW Art

43 Eski IPRG Art 45a ; mutad meskeni İsviçre'de bulunan küçüğün, İsviçre'de evlenmekle veya yurt dışında yaptı̆̆ evlenmenin tanınmasıyla ergin olacağını düzenlemekteydi.

44 Anne Wijffelman, 'Child marriage and Family Reunification: An Analysis under the European Convention on Human Rights and Dutch Forced Marriage Prevention Act' (2017) 35(2) Netherlands Quarterly of Human Rights 104, 104-105, $<$ https://journals.sagepub.com/doi/pdf/10.1177/0924051917708384> Erişim Tarihi 07 February 2020.

45 Wet Tegengaan Huwelijksdwang, Geldend van 05-12-2015, Staatsblad 2015, 373.

46 Burgerlijk Wetboek Boek 1, Personen- en familierecht. Burgerlijk Wetboek Boek 10, Internationaal Privaatrecht.

47 Bu kapsamda; BW Art 1:31/2 ve 3 uyarınca, 16 yaşını doldurmuş olan ve kadının hamile olduğunu veya hâlihazırda doğum yaptığını doktor raporu ile belgelemesi halinde evlenmeye izin veren hüküm ile 18 yaşından küçüklerin Adalet Bakanlığı'nın izni ile evlenmelerine izin veren hüküm; BW Art 1:35 uyarınca, 17 yaşını doldurmuş olan küçüğün yasal temsilcisinin rızasıyla evlenmesine izin veren hüküm; BW Art 1:36 uyarınca, 17 yaşını doldurmuș olan küçüğün mahkeme kararıyla evlenmesine izin veren hüküm; BW Art 1:47 uyarınca, küçüğün izin ile evlenmesinde izni vermeye yetkili makamı düzenleyen hükümler yürürlükten kaldırılmıştır. 
1:69:1 ve BW Art 1:77 uyarınca, mutlak butlanla batıl sayılmıştır. Bununla birlikte; BW Art 1:74'te yapılan değişiklikle, evlenme anında 18 yaşını doldurmamışs olan kü̧̈üğ̈̈n, talep anında 18 yaşın doldurması halinde, evlenmenin hükümsüzlüğ̈̈nün talep edilemeyeceği de hüküm altına alınmıştır.

Ayrıca BW Art 1:44'te yapılan değişiklikle; taraflardan en az birinin Hollanda vatandaşl olmasl veya Hollanda'da mutad meskeninin bulunması durumunda, Hollanda Medeni Kanunu'nda yer alan ve asgari evlenme yaşın da içeren evlenme engellerinin her iki eş bakımından aranacağı hüküm altına alınmıştır.

$\mathrm{Bu}$ değişikliğe paralel olarak "evlenmeye uygulanacak hukuk"ta da değişiklik yapılmıştır. Eski BW Art 10:28 uyarınca, "(1) eşlerden birinin Hollanda vatandaşı olması veya Hollanda'da mutad meskeni bulunması halinde Hollanda hukukunda veya (2) eşlerden her birinin kendi milli hukukunda" öngörülen evlenme ehliyet ve şartlarına uygun şekilde yapılmış evlenmelerin, Hollanda hukukuna göre geçerli olacağ1 yönündeki düzenlenme kaldırılmıştır. Yerine, yeni BW Art 10:28'de, Hollanda'da yapllan evlenmeler bakımından, evlenme ehliyet ve şartlarına, her bir eş bakımından Hollanda hukukunun uygulanacağı hüküm altına alınmıştır ${ }^{48}$. Böylelikle, eşlerden birinin milli hukuku 18 yaşın altındaki evliliklere müsaade ediyor olsa dahi, iki eş bakımından da Hollanda hukuku dikkate alınacağından, bu evlilik Hollanda'da yapilamayacaktır.

Hollanda dışında yapılan evlenmelere uygulanacak hukuka ilişkin de bir değişiklik getirilmiştir. BW Art 10:31 uyarınca; Hollanda dışında yapllan evlenmeler, evlenmenin gerçekleştiği ülke hukukuna tabidir. Buna karşılık; BW Art 10:32'ye getirilen değişiklikle; Hollanda dışında yapılan evlenmenin tanınması açıkça kamu düzenine aykırı ise ve her halükarda, Hollanda dışında yapılan evlenme anında eşlerden biri 18 yaşını doldurmamışsa, tanıma talebi anında her iki eş de 18 yaşını doldurmadıkça, bu evlenmenin Hollanda'da tanınmayacağı açıkça hüküm altına alınmıştır (BW Art 10:32:c) $)^{49}$. Böylelikle, Hollanda kanun koyucusu, Hollanda Medeni Kanunu'nda düzenlenen evlenme yaşına ilişkin düzenlemelerin, Hollanda dışında yapılan evlenmeler bakımından da, kamu düzenine aykırılık değerlendirmesine ihtiyaç kalmaksızın, doğrudan uygulanmasını ve BW Art 1:69:1 ve BW Art 1:77 uyarınca mutlak butlanla batıl olmasını temin etmiştir.

Hollanda hukukunda, çocuk yaşta evlilikler ile mücadele etmek üzere getirilen hükümlerde, İsviçre hukukundan farklı olarak, "evliliğin devamının küçügün üstün yararına olması" gibi herhangi bir istisna hükmü ise getirilmemiştir.

\footnotetext{
48 BW Art 10:28 uyarınca, Hollanda'da gerçekleștirilen evlenmelerin Hollanda hukukuna tabi kılınmasıyla, BW Art 10:29'da; evlenmeye uygulanacak hukukun kamu düzenine açıkça aykırı olması ve her halükarda müstakbel eşlerden birinin 15 yaşını doldurmamış olması halinde evlenmenin mümkün olmayacağını öngören hükme ihtiyaç kalmadığından, bu hüküm tamamen yürürlükten kaldırılmıştır.

49 Hollanda Medeni Kanunu Art 10:32'de gerçekleştirilen bu değişikliğin, mültecilerin aile birleşmesi taleplerine etkisine iliş̧kin değerlendirmeler için bkz Wijffelman (n 44) 114ff.
} 


\section{Alman Hukuku}

Almanya, diğer Avrupa ülkelerine nazaran, Suriye'den en fazla sayıda iltica talebini kabul etmiş ülkedir. İltica taleplerinin artması ile birlikte; Almanya'da da çocuk yaşta evliliklerde artış gözlenmiştir. İçişleri Bakanlığı'ndan yapılan açıklamada, Temmuz 2016 itibariyle, Almanya'da 1475 adet çocuk yaşta evlilik vakası kaydedildiği, bunlardan 1152 tanesinin tarafının kız çocukları olduğu, 361 tanesinin 14 yaşın altında olduğu açıklanmış ve bu evliliklerden 664'ünün Suriye'den, 157'sinin Afganistan'dan, 100'ünün Irak'tan ve 65 tanesinin de Bulgaristan'dan gelen mülteci çocuklar olduğu belirtilmiştir ${ }^{50}$.

Almanya'da, çocuk yaşta evliliklerle mücadele etmek üzere, 22 Temmuz 2017 tarihinde yürürlüğe giren "17 Temmuz 2017 tarihli Çocuk Evliliklerle Mücadele Kanunu”nu (Gesetz zur Bekämpfung von Kinderehen) $)^{51}$ kabul edilmiştir. 2017 tarihli Çocuk Evliliklerle Mücadele Kanunu; başta Alman Medeni Kanunu (Bürgerliches Gesetzbuch/BGB) $)^{52}$ ve kanunlar ihtilafı kurallarının düzenlendiği Kanun (Einführungsgesetz zum Bürgerlichen Gesetzbuche/EGBGB) ${ }^{53}$ olmak üzere, Alman İltica Kanunu (Asylgesetz) ${ }^{54}$ ve Alman Yabanc1lar Kanunu (Aufenthaltsgesetz) ${ }^{55}$ gibi pek çok kanunda, çocuk yaşta evliliklerin önlenmesine ve tanınmamasına yönelik önemli değişiklikler getirmiştir.

Bu kapsamda; Alman Medeni Kanunu'nda (BGB), “evlenme yaşı"nı düzenleyen BGB $\S 1303$ 'de yer alan ve eşlerden birinin 16 yaşını doldurmuş olması halinde hâkim kararıyla evlenmeye imkân veren hüküm kaldırılmış ve asgari evlenme yaşı, istisnasız olarak 18 yaşa yükseltilmiştir. 16 yaş altı evliliklerin ise, yoklukla malul olacağı açıkça hüküm altına alınmıştır. Buna bağlı olarak, "evlenmenin iptal edilebilirlik sebepleri”ni düzenleyen BGB § 1314'te yer alan ve 16 yaş altı evliliklerin iptal edilebilir olduğunu öngören hüküm değiştirilerek; evlenme anında 16 yaşını doldurmuş fakat 18 yaşını doldurmamış küçüklerin evliliğinin iptal edilebilir olduğu hüküm altına alınmışıır ${ }^{56}$. Böylelikle, Alman hukuku uyarınca, 16 yaş altı evlilikler yok hükmünde kabul edilirken; 18 yaş altı evlilikler ise, iptal edilebilirlik sebebi olarak düzenlenmiştir.

\footnotetext{
50 Bkz AFP, 'Germany to crack down on forign child marriages' (The Local Germany, 5 April 2017) <https://www.thelocal. de/20170405/germany-cracks-down-on-foreign-child-marriages> Erişim Tarihi 11 February 2020.

${ }_{51}$ Gesetz zur Bekämpfung von Kinderehen vom 17 Juli 2017, Bundesgesetzblatt Jahrgang 2017,Teil I, Nr 48, ausgegeben zu Bonn am 21 Juli 2017.

52 Bürgerliches Gesetzbuch in der Fassung der Bekanntmachung vom 2 Januar 2002 (BGB1 I S 42, 2909; 2003 I S 738).

53 Einführungsgesetz zum Bürgerlichen Gesetzbuche in der Fassung der Bekanntmachung vom 21 September 1994 (BGB1 I S 2494; 1997 I S 1061)

${ }^{54}$ Asylgesetz in der Fassung der Bekanntmachung vom 2 September 2008 (BGBl I S 1798).

55 Aufenthaltsgesetz in der Fassung der Bekanntmachung vom 25 Februar 2008 (BGB1 I S 162).

56 BGB § 1316'da gerçekleştirilen değişiklikle; asgari evlenme yaşına ilişkin BGB § 1303 c. 1 hükmünün ihlali sebebiyle, yetkili idari makamlar yanında, küçüğün kendisinin de, yasal temsilcisinin onayı gerekmeksizin, evliliğin iptali başvurusunda bulunabileceği hüküm altına alınmıştır.
} 
BGB § 1314 uyarınca, eşlerden birinin küçük olması halinde, evliliğin iptal edilebilir olmasının istisnaları ise, BGB $§ 1315 / 1$ 'de düzenlenmiştir. Buna göre; (a) küçük olan eşin evlenmenin iptalinin talep edildiği sırada 18 yaşını doldurmuş olması ve evliliğin devamına ilişkin serbest ve tam rızasının bulunması hali ile (b) olağanüstü hallerde, evlenmenin iptalinin küçük olan eş bakımından istisnai şekilde evliliğin devamını mecbur kılacak derecede ağır sonuçlara yol açacak olması halinde ${ }^{57}$, evliliğin iptaline hükmedilmeyeceği hüküm altına alınmıştır. Özellikle BGB § 1315/1(b)'de yer alan istisna hükmü; İsviçre hukukundakine benzer şekilde, AKPM'nin, yurt dışında yapılan çocuk yaşta evliliklerin tanımamanın istisnası olarak ortaya koyduğu, “mağdur tarafindan başka türlü ileri sürülemeyecek evlenmenin sonuçlarına ilişkin hakların güvence altına alınabilmesi amacıyla, tanımanın, mă̆durun üstün yararına olduğu haller" kriterine uygunluk taşımaktadır ${ }^{58}$.

Alman Medeni Kanunu'nda 16 yaşın altındakiler tarafından yapılan evliliklerin yok hükmünde sayılmasına paralel bir değişiklik, Alman kanunlar ihtilafı kurallarına da getirilmiştir. Evlenmeye uygulanacak hukuku düzenleyen EGBGB Art 13/1 uyarınca; evlenme ehliyet ve şartlarına uygulanacak hukuk, "eşlerden her birinin milli hukuku'dur. Ancak EGBGB Art 13/3'e getirilen yeni düzenlemede; Art 13/1 uyarınca eşlerden birinin milli hukukunun yabancı bir hukuk olması halinde dahi, iki durumda, doğrudan Alman hukukunun uygulanacağı hüküm altına alınmıştır. Buna göre; eşlerden birinin Art 13/1 uyarınca yabancı hukuka tabi olduğu hallerde;

(1) eşlerden biri evlenme anında 16 yaşını doldurmamışsa, Alman hukuku uygulanır ve evlilik yok hükmündedir ve

(2) eşlerden biri evlenme anında 16 yaşını doldurmuş fakat 18 yaşını doldurmamışsa, Alman hukuku uygulanır ve BGB $\S 1315 / 1$ 'de düzenlenen istisnalar saklı kalmak kaydiyla evlilik iptale tabidir.

Böylelikle, Alman kanun koyucu, Alman Medeni Kanunu ile getirilen evlenme yaşına ve hükümsüzlük hallerine ilişkin düzenlemelerin, Almanya dışında yapılan yabancı hukuka tabi evlenmeler bakımından da, kamu düzenine aykırılık değerlendirmesine ihtiyaç kalmaksızın, doğrudan uygulanmasını temin etmiştir ${ }^{59}$.

57 Kanunun gerekçesinde, "istisnai şekilde evliliğin devamını mecbur kılacak derecede ağır sonuçlar” örnek olarak, ağır bir hastalığa yakalanmak veya intihar tehlikesinin gösterildiği ifade edilmektedir. Bkz Nina Dethloff, "Child Brides on The Move: Legal Responses to Culture Clashes' (2018) 32(3) International Journal of Law, Policy and The Family 302, 310 $<$ https://doi.org/10.1093/lawfam/eby008> Erişim Tarihi 11 February 2020.

58 PACE 'Resolution on Forced Marriages and Child Marriages 2005' (n 12) para 14.2.4.

59 EGBGB Art 229 § 44/4 uyarınca, hükmün uygulama alanı iki halle sınırlandırılmıştır. Buna göre; hüküm, (1) küçük olan eşin 22 Temmuz 1999'dan önce doğmus olması veya (2) uygulanacak yabancı hukuka göre evliliğin geçerli olması ve küçük olan eş erginlik yaşına ulaşıncaya kadar eşlerden hiçbirinin Almanya'da mutad meskeninin bulunmaması halinde uygulama alanı bulmayacaktır. 
2017 tarihli Çocuk Evliliklerle Mücadele Kanunu, Alman kamuoyunda, özellikle yabancı ülkede yapılan 16 yaş altı evliliklerde kamu düzenine aykırılık değerlendirmesini devre dişı birakarak bu evlilikleri doğrudan hükümsüz sayan EGBGB Art 13/3 düzenlemesi nedeniyle tartışmalara yol açmıș ve hatta Kanun yakın bir zamanda Alman Federal Mahkemesi (Bundesgerichtshof, BGH) kararına da konu olmuştur ${ }^{60}$.

Davaya konu olay; Ağustos 2015'te Balkanlar üzerinden Suriye'deki savaş yüzünden Almanya'ya iltica eden Suriye vatandaşı bir çift hakkındadır. Olayda çift, 10 Şubat 2015 tarihinde Suriye Şeriat Mahkemesi'nde evliliklerini tescil ettirmiştir. Evlenme anında erkek 21 yaşında, kız çocuğu ise 14 yaşındadır. Çiftin Almanya'ya girişi ve Schweinfurt tesislerine kayıt olmalarıyla birlikte; Alman Gençlik İdaresi'nin kararıyla, 14 yaşındaki kız çocuğu, refakatsiz çocukların yerleştirildiği gençlik koruma tesisine yerleştirilmiş ve Aschaffenburg Bölge Aile Mahkemesi'nin (Amtsgericht Aschaffenburg) Eylül 2015 tarihli tedbir kararı ile Gençlik İdaresi vasi olarak atanmıştır. Suriyeli kocanın, vesayet kararının yeniden incelenmesi için Aschaffenburg Bölge Aile Mahkemesi’nde açtı̆̆ı davada, mahkeme, Aschaffenburg Gençlik İdaresi'ni haklı bularak vesayet kararını kaldırmamış ve tarafların her hafta sonu belirlenen saatler arasında ve üçüncü bir kişinin nezaretinde kişisel ilişki kurabilmesine hükmetmiştir ${ }^{61}$.

Alman Gençlik İdaresi'nin kararı temyiz etmesi üzerine, dava, Bamberg Bölge Yüksek Mahkemesi'ne (Oberlandesgericht Bamberg) taşınmıştır. 2017 tarihli Çocuk Evliliklerle Mücadele Kanunu'nun yürürlüğe girmesinden önce davayı gören mahkeme 2016 tarihli kararında; evlenmenin şekline (EGBGB Art 11) ve evlenmeye ehliyet ve şartlarına uygulanacak hukuku düzenleyen (EGBGB Art 13/1) hükümler uyarınca, evlenmeye Suriye hukukunun uygulanacağını; Suriye Kişisel Durumlar Kanunu'na göre, evlenme yaşının erkekler için 18, kadınlar için 17 olduğunu, ancak erkekler için 15, kadınlar için 13 yaşında hâkim onayıyla evlenmenin tescili mümkün olduğundan, dava konusu evlenmenin uygulanacak hukuk olan Suriye hukukuna göre şeklen ve ehliyet ve şartlar yönünden geçerli olduğunu; EGBGB Art 6 uyarınca kamu düzeni müdahalesinin, yabancı ülkede yapılan ve eski BGB $§ 1303$ 'te yer alan hâkim kararıyla evlenme yaşı olan 16 yaş altı evliliklerin otomatik olarak tanınamayacağı anlamına gelmediğini; yabancı ülkede yapılan evliliklerde kaç yaşına kadar küçüklerin evlenmesinin kamu düzenine açıkça aykırılık teşkil ettiğinin Alman içtihatlarında tartışmalı olduğunu; ancak bu dava bakımından kamu düzenine aykırılık tartışmasına gerek olmadığını, zira Suriye hukukunda 13 yaşındaki kız çocuklarının evlenmesine müsaade eden hükmün Alman kamu düzenini açıkça ihlal ettiği değerlendirilse dahi,

\footnotetext{
60 Tartışmalar için bkz Dethloff (n 57) 308-310; Jacqueline Kusserow, 'Regulating Child Marriage: Germany’s Latest Foray and Possible Lessons For Canada' (Canadian Icon) <http://canadianicon.org/regulating-child-marriage-germanys-latestforay-and-possible-lessons-for-canada/\#_ednref12> Erişim Tarihi 11 February 2020

${ }^{61}$ AG Aschaffenburg, Beschluss vom 07.03.2016 - 7 F 2013/15
} 
eski BGB § 1314 uyarınca asgari evlenme yaşının altındaki evliliklerin geçersiz değil iptal edilebilir olduğunun kabul edildiğini ve dava konusu evlilik bakımından herhangi bir iptal talebinin bulunmadığını; ayrıca Alman Ceza Kanunu § 182/3 uyarınca, 14 yaşını doldurmuş kişilerle cinsel birlikteliklerin suç teşkil etmesi için küçüğün tecrübesizliğinin suiistimal edilmiş olmasının arandığını; Çocuk Haklarına Dair Sözleşme'de asgari evlenme yaşına ilişkin herhangi bir hüküm bulunmadığını ve olayda evliliğin zorla yapıldığına ilişkin herhangi bir veri olmadığını; eşlerin Almanya'ya entegrasyonunun sağlanması bakımından Suriye'de yaptıkları evliliğin tanınmamasının şart olmadığını; bu gerekçelerle evlilik geçerli olduğundan, evli bir kişinin vesayet atına alınmasının mümkün olmadığını ifade ederek, Alman Gençlik İdaresi'nin talebini reddetmiş ve Aschaffenburg Bölge Aile Mahkemesi'nin vasi atanmasına ilişkin kararını re'sen bozmuştur ${ }^{62}$.

Kararın Alman Federal Mahkemesi'ne (Bundesgerichtshof, BGH) taşınması üzerine, BGH 2018 tarihli kararında, öncelikle, 2017 tarihli Kanun geçmişe etkili olmadığından davaya konu olay bakımından uygulanamayacağına hükmederek; Bamberg Bölge Yüksek Mahkemesi'nin taraflar arasındaki Suriye hukukuna uygun evliliğin Alman hukukuna göre geçerli olduğuna ve Alman kamu düzenini açıkça ihlal etmediğine ilişkin gerekçelerine katılmıştır ${ }^{63}$.

BGH, ayrıca kararında, 2017 tarihli Çocuk Evliliklerle Mücadele Kanunuyla getirilen ve Almanya dışında yapılmış yabancı hukuka tabi evliliklerde, eşlerden birinin evlenme anında 16 yaşını doldurmamış olması halinde Alman hukukunun uygulanacağı ve evliliğin yok hükmünde sayılacağ yönündeki EGBGB Art 13/3(1) hükmünün, Alman Anayasası'nın, insan onuru başlıklı 1. maddesine, kişi hürriyeti başlıklı 2. maddesine, eşit muamele başlıklı 3. maddesine ve evlenme ve aile hayatının korunması başlıklı 6. maddelerine aykırı olduğunu değerlendirmiş, yargılamaya ara vererek meseleyi Alman Federal Anayasa Mahkemesi'ne (Bundesverfassungsgericht) göndermiştir ${ }^{64}$.

EGBGB m 13/3(1) hükmünün, Anayasa'ya aykırı olduğuna ilişkin değerlendirmesinde Çocuk Haklarına Dair Sözleşme'ye de atıf yapan BGH, Sözleşme'nin 12. maddesi uyarınca, çocuğun yaşı ve olgunluk derecesine uygun olarak, çocuğun kendini ilgilendiren her konuda görüşlerini serbestçe ifade etme hakkını ve 3. maddesi uyarınca, çocukları ilgilendiren tüm faaliyetlerde "çocuğun üstün menfaati"nin gözetilmesi ilkesini hatılatarak, EGBGB m 13/3(1) hükmünün, "çocuğun üstün menfaati”nin temini için zorunlu olan somut olay bazında değerlendirme yapma imkânını ortadan kaldırdığına dikkat çekmiştir ${ }^{65}$.

\footnotetext{
OLG Bamberg, Beschluss vom 12.05.2016 - 2 UF 58/16.

3 BGH, Beschluss vom 14.11.2018 - XII ZB 292/16, para. 20-48.

${ }^{64}$ BGH, Beschluss vom 14.11.2018 - XII ZB 292/16, para. 67-84.

65 BGH, Beschluss vom 14.11.2018 - XII ZB 292/16, para. 46, 54, 81-84.
} 
Alman doktrininde de, 2017 tarihli Çocuk Evliliklerle Mücadele Kanunu hükümleri, Almanya'da yapılan evlilikler bakımından olumlu karşılanmakla birlikte; evlenme yaşına ve sonuçlarına ilişkin ilgili hükümlerin, Almanya dışında eşlerin tabi oldukları milli hukuka göre geçerli bir şekilde yaptıkları evliliklere de uygulanması eleştirilere yol açmıştır. Bu eleştirilerde, özellikle, yeni EGBGB Art 13/3(1) hükmünün, kamu düzenine ilişkin özel bir hüküm ihdas ederek, genel kamu düzenine aykırılık hükmü olan EGBGB Art 6'nın üstüne çıktığ1 ve bu şekilde, kamu düzenine aykırılık değerlendirmesinin, her bir somut olayda, çocuğun üstün menfaati gözetilerek yapılmasını engellediği ifade edilmektedir ${ }^{66}$.

\section{Değerlendirme}

Avrupa ülkelerinin çocuk yaşta evlilikleri önlemeye yönelik mevzuat değişikliklerine genel olarak bakıldığında; medeni kanun hükümlerinde, evlenme yaşının 18 yaşa yükseltildiği, 18 yaş altı evlenmeye imkân veren hükümlerin bertaraf edildiği ve çocuk yaşta evlilikler bakımından hükümsüzlük hallerinin ağırlaştırıldığı görülmektedir.

Milletlerarası özel hukuk kurallarında yapılan değişiklerin ise, çok daha radikal olduğu değerlendirilebilir. Öncelikle, yabancılık unsuru içeren çocuk yaşta evlenmelerin, ülke içinde yapılmasını önlemek ve geçersiz olmalarını temin etmek amacıyla, kanunlar ihtilafi hukukunda genel olarak kabul edilen, evlenmenin ehliyet ve şartlarının, "taraflardan her birinin evlenme anındaki milli hukukuna" tabi olması kuralından vazgeçildiği ve daha korumacı bir politika izlenerek, evlenmenin geçerliliğinin, "evliliğin gerçekleştiği ülke hukukuna" (lex loci celebrationis) tabi k1lındığ1 görülmektedir (IPRG Art 44, BW Art 10:28, EGBGB Art 13/3). Bunun yanında; yabancı ülkede tarafların milli hukuklarına göre geçerli olarak yapılmış çocuk yaşta evliliklerin geçerliliğinin de, çocuk yaşta evliliklerin tanınmasını engelleyici hükümler vasıtasıyla, dolaylı olarak, kendi hukuklarına (lex fori) tabi kıldıkları görülmektedir (IPRG Art 45a, BW Art 10:32:c, EGBGB Art 13/3). Böylelikle; gerek yurt içi gerekse yurt dışında yapılan evliliklerin geçerliliğinde, kamu düzenine aykırılık değerlendirmesi dışlanarak, yabancı ülkede yapılan çocuk yaşta evliliklerin doğrudan hükümsüz olması temin edilmiştir.

Ayrıca, İsviçre ve Alman hukuklarında, yabancı ülkede yapılan çocuk yaşta evliliklerin geçersiz sayılması ve tanınmamasında, "evliliğin devamının çocuğun üstün yararına olmasl" haline yönelik istisnalar getirilmiş olmakla birlikte; Hollanda hukukunda, bu yönde bir istisnaya dahi yer verilmediği görülmektedir.

66 Dethloff (n 57) 310; The Draft Legislation on Child Marriage and Private International Law: An Interview with Institute Director Jürgen Basedow, <https://www.mpipriv.de/files/pdf4/Interview_with_Jrgen_Basedow_The_Draft_Legislation_ on_Child_Marriage_and_Private_International_Law1.pdf>07 February 2020. 
Kanaatimizce; bu mevzuat değişikliklerinde, ülke içerisinde gerçekleştirilen evlilikler bakımından, evlenme yaşının yükseltilmesi ve çocuk yaşta evliliklerin hükümsüzlük yaptırımına tabi kılınması yerinde olmuştur. Bununla birlikte, yabancı ülkede tarafların milli hukuklarına göre geçerli bir şekilde yapılmış evliliklerin geçerliliğine uygulanacak hukukta, çocuk yaşta evliliklerin tanınmamasına yönelik getirilen yasaklayıcı düzenlemelerle, somut olay bazında kamu düzenine aykırılık değerlendirmesinin işlevsiz hale getirilmesi; BM Çocuk Hakları Sözleşmesi m 3/1 uyarınca, "çocuğun üstün menfaati”nin korunması" yükümlülüğünü zedeleyecek niteliktedir. Kanaatimizce, bu tarz tepkisel kanun değişiklikleri yerine, yetkili yabancı hukukun uygulanmasında kamu düzenine aykırılık aracının uygun bir şekilde kullanılması, gerek toplumsal değerlerin gerekse mağdur çocuğun üstün menfaatlerinin korunması bakımından milletlerarası özel hukuk anlamında daha doğru bir çözüm sunacaktır.

\section{Geçici Koruma Altındaki Suriyelilerin Çocuk Yaşta Evliliklerinin Türk Hukukuna Göre Geçerliliği}

Suriye'de yaşanan olaylar sebebiyle Nisan 2011 tarihinden sonra Türkiye'ye gerçekleşen göç akını neticesinde, Türkiye'deki çocuk yaşta evlilik oranları artmıştır. Çocuk yaşta evliliklere Suriye hukukunun imkan tanıması bunda etkili olduğu gibi; Türkiye' deki iltica koşulları da bu tür evliliklerin artışını hızlandıran bir faktör olarak karşımıza çıkmaktadır.

Çocuk yaşta evliliklerin Suriyeliler arasında yaygınlaşması, Türkiye bakımından sosyolojik ve toplumsal bir problem olarak karşımızda durmakla birlikte; bu evliliklerin geçerli sayılıp sayılmayacağı ve bu tarz evlilikleri önlemek için Avrupa ülkelerine benzer şekilde birtakım mevzuat değişikliklerinin gerekip gerekmediği meseleleri de problemin hukuki boyutu olarak karşımıza çıkmaktadır. Unutulmamalıdır ki; Türkiye, taraf olduğu milletlerarası sözleşme hükümleri uyarınca, ülkesinde, hangi milliyetten olursa olsun, çocuk yaşta evlilikleri önleyecek tedbirleri alma yükümlülüğündedir.

Bu itibarla aşağıda, Türkiye'de geçici koruma altında bulunan Suriyelilerce yapılan çocuk yaşta evliliklerin Türk hukukuna göre geçerliliği incelenirken, Avrupa ülkelerine benzer değişikliklere ihtiyaç olup olmadığ 1 da yeri geldikçe değerlendirilecektir. Suriyelilerin Türkiye'ye gelmeden önce veya Türkiye'ye girdikten sonra yaptıkları çocuk yaşta evliliklerin Türk hukukuna göre geçerliliği ise; özellikle geçici koruma altındaki Suriyelilerin MÖHUK m 13 uyarınca "milli hukukları" olarak hangi hukukun uygulanacağı ve bu bağlamda MÖHUK m 4/1(a) hükmü kapsamına girip girmedikleri; Suriye hukukunun uygulanması gereken durumlarda temini ve Suriye hukukunda yer alan evlenme yaşına ilişkin hükümlerin Türk kamu düzenine aykırı olup olmadığı ile Suriye hukukuna göre geçerli bir 
çocuk yaşta evliliğe Türk hukukunda geçerlilik tanınmamasının AİHS m 8 ve 12 kapsamında bir ihlal teşkil edip etmeyeceği meseleleri etrafında ele alınacaktır.

\section{A. Çocuk Yaşta Evliliklerin Geçerliliğine Uygulanacak Hukuk}

\section{Evlenme Yaşına Uygulanacak Hukuka İlişkin Kanunlar İhtilafı Kuralı}

İçerisinde yabancılık unsuru bulunan çocuk yaşta evliliklerin geçerliliğine uygulanacak hukuku tespit etmeden önce, hukuki meselenin (bağlama konusunun) vasıflandırılması gerekmektedir. Türk milletlerarası özel hukukunda bağlama konusunun vasıflandırılmasında lex fori prensibi esas alınmaktadır. Evlenme yaşı, lex fori olarak Türk hukukunda, evlenme ehliyetine sahip olmanın şartlarına ilişkin bir mesele olarak nitelendirilmektedir ${ }^{67}$. Bu itibarla, evlenme yaşına uygulanacak hukuk, 5718 sayılı Milletlerarası Özel Hukuk ve Usul Hukuku Hakkında Kanun'un ${ }^{68}$ (MÖHUK) evlenme ehliyet ve şartlarına uygulanacak hukuku gösteren 13. maddesinin 1. fikrası uyarınca tespit edilecektir ${ }^{69}$.

MÖHUK m 13/1; evlenme ehliyet ve şartlarını ve bu kapsamda evlenme yaşını, "taraflardan her birinin evlenme anındaki milli hukuku"na tabi kılmaktadır. Buna göre; erkeğin milli hukukundaki evlenme yaşı da dâhil evlenme ehliyet ve şartları sadece erkeğe, kadının milli hukukundaki şartlar ise sadece kadına uygulanmaktadır ${ }^{70}$. Eşlerin milli hukukunun tespitinde evlenme anı sabit statü olarak öngörüldüğünden, her bir eşin evlenme anındaki milli hukukuna bakılacaktır. Bu sebeple, evlenme işlemi gerçekleştikten sonra eşlerden herhangi birinin vatandaşlığının değişmesi, evlenme ehliyet ve şartlarına uygulanacak hukuku etkilemeyecektir.

Türkiye'de geçici koruma statüsü altında bulunan Suriyelilerce yapılan evliliklerin evlenme ehliyet ve şartlarına uygulanacak hukukun MÖHUK m 13/1 uyarınca belirlenmesinde karşılaşılan ilk sorun, Suriyeli eşin "milli hukuku”nun tespitidir. Bu noktada tartışma, geçici koruma altındaki Suriyelilerin "milli hukukları"nın MÖHUK m 4/1(a) kapsamında "mülteciler" gibi tespit edilip edilmeyeceğine ilişkindir.

\footnotetext{
7 Mustafa Dural, Tufan Öğüz ve Mustafa Alper Gümüş, Türk Özel Hukuku Cilt III Aile Hukuku (14. Bası, Filiz Kitapevi 2019), 48; Bilge Öztan, Aile Hukuku (6. Bası, Turhan Kitabevi 2015) 129; Turgut Akıntürk ve Derya Karaman, Türk Medeni Hukuku Aile Hukuku Cilt 2 (20. Bası, Beta 2017) 62; Ahmet M Kılı̧̧oğlu, Aile Hukuku (3. Bası, Turhan Kitabevi 2017$) 36$.

${ }_{68}$ Milletlerarası Özel Hukuk ve Usul Hukuku Hakkında Kanun, Kanun Numarası: 5718, Kabul Tarihi: 27.11.2007, RG 12.12.2007/26728.

69 Yücel Sayman, Türk Devletler Hususi Hukukunda Evlenmenin Kuruluşu (Fakülteler Matbaası 1992) 16-22; Nihal Uluocak, Milletlerarası Özel Hukuk Dersleri (2. Bası, Filiz Kitabevi 1989) 48, 50-51; Aysel Çelikel ve B Bahadır Erdem, Milletlerarası Özel Hukuk (15. Bası, Beta 2017) 226; Ergin Nomer, Devletler Hususi Hukuku (22. Bas1, Beta 2017) 240; Cemal Şanl1, Emre Esen ve İnci Ataman-Figanmeșe, Milletlerarası Özel Hukuk (7. Bas1, Beta 2019) 130; Gülören Tekinalp ve Ayfer Uyanık, Milletlerarası Özel Hukuk Bağlama Kuralları (5. Bası, Vedat Kitapçı1ık 2016) 131-132; Ziya Akıncı ve Cemile Demir Gökyayla, Milletlerarası Aile Hukuku (Vedat Kitapçılık 2010) 17; Vahit Doğan, Milletlerarası Özel Hukuk (5. Bası, Savaş Yayınevi 2019) 320-321.

70 Nomer (n 69) 239; Çelikel, Erdem (n 69) 228; Şanlı, Esen ve Ataman-Figanmeşe (n 69) 130; Tekinalp ve Uyanık (n 69) 132; Akıncı ve Demir Gökyayla (n 69) 16-17.
} 


\section{Evlenme Yaşına Uygulanacak Hukukun Tespitinde MÖHUK m 4/1(a)'nın Geçici Koruma Altındaki Suriyeliler Bakımından Uygulanması}

5718 sayılı MÖHUK'un 4. maddesi; vatansızlık, mültecilik veya birden fazla vatandaşlı̆ga sahip olma gibi, milli hukukun tespitinde belirsizliklere sebebiyet veren durumlara çözüm getirmeye yönelik bir düzenlemedir. MÖHUK m 4/1(a) hükmüne göre, kanunlar ihtilafı kurallarınca yetkili hukukun "vatandaşlık" esasına göre tayin edildiği hallerde; vatansızlar ve mülteciler hakkında yerleşim yeri, bulunmadığı hâllerde mutad mesken, o da yok ise dava tarihinde bulunduğu ülke hukuku uygulanır. Buna göre; ilgili, vatansız veya mülteci konumunda ise, bu kişinin milli hukuku olarak, yerleşim yeri, yoksa mutad mesken, o da yoksa dava tarihinde bulunduğu ülke hukuku uygulanacaktır.

MÖHUK m 4/1(a) hükmü, vatansız ve mülteci konumundakiler bakımından milli hukukun tespiti için net ve pratik bir çözüm getirmekte ise de; 6458 sayılı Yabancılar ve Uluslararası Koruma Kanunu ${ }^{71}$ (YUKK) ile düzenlenen diğer koruma türleri olan, şartl mülteci, ikincil koruma ve çalışmamızın öznesini teşkil eden geçici koruma bakımından da uygulanıp uygulanmayacağı tartışmalıdır. Bu sorunun cevabını verebilmek için, hükümde yer alan mülteci ibaresinden ne anlaşılması gerektiği tespit edilmelidir. Bu tespitin daha rahat yapılabilmesi için öncelikle, Türk iltica hukukundaki koruma türlerinden kısaca bahsetmekte yarar vardır.

\section{a. Genel Olarak Türk İltica Hukukunda Koruma Statüleri}

5718 sayılı MÖHUK'un hazırlandığı ve yürürlüğe girdiği 2007 yılında, 6458 sayılı YUKK henüz yürürlükte değil idi ve mültecilerin tabi oldukları hukuki rejim Türk iç hukuk mevzuatında detaylı bir biçimde düzenlenmemişti. O tarihte Türk iltica hukuku, Türkiye'nin 1961 yılından beri taraf olduğu 1951 tarihli Mültecilerin Hukuki Durumuna Dair Cenevre Konvansiyonu ${ }^{72}$ (1951 Cenevre Konvansiyonu) ve bu Konvansiyon'a ek 1967 New York Protokolü ${ }^{73}$ ile mülga 1994 tarihli İltica ve Göç Yönetmeliğ $i^{74}$ 'nde (1994 Yönetmeliği) yer alan hükümlerle düzenlenmekteydi. 1951 Cenevre Konvansiyonu ve 1967 New York Protokolü'ne konan ve halen muhafaza edilen coğrafi sınırlama sebebiyle Türkiye'de, sadece Avrupa ülkelerinden ${ }^{75}$ gelenlere

\footnotetext{
Yabanc1lar ve Uluslararası Koruma Kanunu, Kanun Numarası: 6458, Kabul Tarihi: 04.04.2013, RG 11.04.2013/28615.

72 Convention Relating to the Status of Refugees, United Nations General Assembly resolution 429 (V) of 14 December 1950. RG. 05.09.1961-10898.

73 Protocol Relating to the Status of Refugees, United Nations General Assembly resolution 2198 (XXI) of 16 December 1967. RG. 05.08.1968-12968.

74 Türkiye’ye İltica Eden veya Başka Bir Ülkeye İltica Etmek Üzere Türkiye'den İkamet İzni Talep Eden Münferit Yabancılar İle Topluca Sığınma Amacıyla Sınırlarımıza Gelen Yabancılara ve Olabilecek Nüfus Hareketlerine Uygulanacak Usul ve Esaslar Hakkında Yönetmelik, Kabul Tarihi: 14.09.1994, RG 30.11.1994/22127.

75 YUKK m 3/1(b) uyarınca; Avrupa ülkeleri, Avrupa Konseyi üyesi olan ülkeler ile Bakanlar Kurulunca belirlenecek diğer ülkelerdir.
} 
"mülteci" statüsü verilmekte; "mülteci" tanımındaki şartlar1" ${ }^{76}$ yerine getirmekle birlikte, Avrupa ülkeleri dışından gelenler ise 1994 Yönetmeliği uyarınca "sı̆̆ınmacı" olarak ifade edilmekte idi (1994 Yönetmeliği m 3).

2013 yılında, Türk iltica hukukunu ayrıntılı ve kapsamlı bir şekilde düzenleyen YUKK'un yürürlüğe girmesi ile birlikte, koruma statüleri, "uluslararası koruma" ve "geçici koruma" olmak üzere iki ana başlık altında kategorize edilmiştir". "Uluslararası koruma” türleri; “mülteci”, "şartlı mülteci” ve "ikincil koruma” olarak belirlenmiştir (YUKK m 3(r)). "Mülteci” kavramı, YUKK m 61'de, 1951 Cenevre Konvansiyonu ve mülga 1994 Yönetmeliği’ndeki tanımlar aynen muhafaza edilerek düzenlenmiştir. YUKK m 62’de, mülga 1994 Yönetmeliği'nde yer alan sı̆̆ınmacı tanımı aynen korunmakla beraber; "sığınmacı" kavramı yerine, "şartlı mülteci" kavramı kullanılmıştır. "Mülteci” ile "şartlı mülteci” arasında sahip oldukları hak ve yükümlülükler bakımından en önemli fark, şartlı mültecilerin Türkiye’de kalmasına, güvenli üçüncü bir ülkeye ${ }^{78}$ yerleştirilinceye kadar izin verilmesidir. Mülteci veya şartlı mülteci olarak nitelendirilememekle birlikte "geri gönderme yasağı" (nonrefoulment) (YUKK m 4) kapsamında koruma sağlanması gereken kişiler için öngörülen "ikincil koruma"79 (subsidiary/secondary protection) statüsü ise, Türk iç hukukunda ilk defa YUKK'un 63. maddesinde tanımlanmıştır ${ }^{80}$.

761967 New York Protokolü ile değiştirilen 1951 Cenevre Konvansiyonu m IA/2 ile Konvansiyonu esas alan mülga 1994 Yönetmeliği m 3 ve 6458 sayılı YUKK m 61 uyarınca, mülteci statüsü şartları; (1) iltica başvurusunda bulunan yabancının menşe ülkesinde, ırkı, dini, tabiiyeti, belli bir toplumsal gruba mensubiyeti veya siyasi düşüncelerinden dolayı zulme uğrayacağından korkması; (2) korkusunun haklı sebeplere dayanması; (3) iltica başvurusunda bulunan yabancının ülkesi dışında bulunması ve (4) iltica başvurusunda bulunan yabancının ülkesinin diplomatik himayesinden yararlanamaması ya da söz konusu korku sebebiyle yararlanmak istememesidir.

77 Belirtilmelidir ki; "geçici koruma” da, esasen bir "uluslararası koruma” sağlama aracı olmakla birlikte; YUKK "uluslararası koruma" kavramını dar bir șekilde tanımlamıș ve "geçici koruma"yı "uluslararası koruma" türleri arasında saymamıștır (YUKK m 3(r)). Türk yabancılar hukukunda, uluslararası koruma statüleri hakkında ayrıntılı bilgi için bkz Aysel Çelikel ve Günseli Öztekin Gelgel, Yabancılar Hukuku (24. Bası, Beta 2018) 158-160; Nuray Ekși, Yabancllar ve Uluslararası Koruma Hukuku (4. Bası, Beta, 2016) 44-55; Vahit Doğan, Türk Yabancılar Hukuku (3. Bası, Savaş Yayınevi 2018) 138146; Bülent Çiçekli, Yabancılar ve Mülteci Hukuku (6. Bas1, Seçkin 2016) 242-245, 300-303, 314.

78 Bir ülkenin "güvenli üçüncü ülke" olarak nitelendirilebilmesi için aranan şartlar YUKK m 74/2'de sayılmıștır. Bir ülkenin başvuru sahibi için güvenli üçüncü ülke olup olmadığı, her başvuru sahibi için ayrı olarak değerlendirilir (YUKK m 74/3). "Güvenli üçüncü ülke" kavramı hakkında ayrıntılı bilgi için bkz Mehmet Özcan, AB Sığınma Hukuku (USAK 2006) 54 vd; Esen Aydın, 'Avrupa Birliği Mevzuatında Güvenli Üçüncü Ülke Kavramı ve Türkiye-AB Geri Kabul Anlaşmasına Yansimaları’ (2018) 38(1) PPIL 11, 14-18.

79 YUKK m 63 uyarınca; mülteci veya şartlı mülteci olarak nitelendirilemeyen, ancak menşe ülkesine veya ikamet ülkesine geri gönderildiği takdirde; (a) Ölüm cezasına mahkûm olacak veya ölüm cezası infaz edilecek, (b) İşkenceye, insanlık dışı ya da onur kırıcı ceza veya muameleye maruz kalacak, (c) Uluslararası veya ülke genelindeki silahlı çatışma durumlarında, ayrım gözetmeyen şiddet hareketleri nedeniyle şahsına yönelik ciddi tehditle karşılaşacak, olması nedeniyle menşe ülkesinin veya ikamet ülkesinin korumasından yararlanamayan veya söz konusu tehdit nedeniyle yararlanmak istemeyen yabancı ya da vatansız kişiye, statü belirleme işlemleri sonrasında ikincil koruma statüsü verilir.

80 İkincil koruma statüsü, 1951 tarihli Cenevre Konvansiyonu m 33 ve Avrupa İnsan Hakları Sözleşmesi (AİHS) m 3 çerçevesinde, "geri gönderme yasağı"ndan (non-refoulment) kaynaklı bir uluslararası koruma türü olması itibariyle Türk hukukunda var olsa da; kavramsal olarak ilk defa YUKK’ta düzenlenmiş ve tanımlanmıştır. Bkz Ekşi, Yabancılar Hukuku (n 77) 53. 
Uluslararası koruma statülerinin yanında; kitlesel akın durumlarında sağlanan "geçici koruma" 81 müessesesi de, bu kavram kullanılarak ilk defa, YUKK m 91 ve 2014 tarihli Geçici Koruma Yönetmeliği ${ }^{82}$ (GKY) ile etraflıca düzenlenmiştir ${ }^{83}$. Geçici Koruma Yönetmeliği'nin 61. maddesiyle 1994 tarihli İltica ve Göç Yönetmeliği yürürlükten kaldırılmış ve Geçici Koruma Yönetmeliği Geçici Madde 1 uyarınca, 28/4/2011 tarihinden itibaren Suriye Arap Cumhuriyeti'nde meydana gelen olaylar sebebiyle geçici koruma amacıyla Suriye Arap Cumhuriyeti'nden kitlesel veya bireysel olarak sınırlarımıza gelen veya sınırlarımızı geçen Suriye Arap Cumhuriyeti vatandaşları ile vatansızlar ve mülteciler, uluslararası koruma başvurusunda bulunmuş olsalar dahi geçici koruma altına alınarak Türk iltica hukukundaki güncel durum tesis edilmiştir.

\section{b. MÖHUK m 4/1(a) Hükmünde Yer Alan “Mülteci”’ İbaresinin Anlamı ve Kapsamı}

Türk iltica hukukundaki koruma türlerine ilişkin bu kısa özetten anlaşılacağ1 üzere; "şartlı mülteci”, "ikincil koruma" ve çalışmamızın öznesini teşkil eden "geçici koruma" kavramları; terminolojik olarak Türk iç hukukunda ilk defa YUKK'un yürürlüğe girmesi ile kullanılmaya başlanan; 5718 sayılı MÖHUK m 4/1(a) hükmü kaleme alındığı tarihte kullanılmayan kavramlardır. Bu nedenle, MÖHUK m 4/1(a) hükmünde, şartlı mülteci, ikincil koruma ve geçici koruma ifadelerinin yer almıyor olması, kanaatimizce, tek başına, lafzi yorumdan hareketle, mültecilik haricindeki bu koruma statülerinin madde kapsamından dışlandığ 1 anlamına gelecek şekilde yorumlanmamalidir ${ }^{84}$.

MÖHUK m 4/1(a) hükmünde yer alan “mülteciler” ifadesinden ne anlaşılması gerektiğinin tespitinde kanaatimizce, maddenin lafzından ziyade, amaca göre yorum yöntemi tercih edilerek, hükmün konuluş amacı (ratio legis) dikkate alınmalıdır.

\footnotetext{
1 Geçici Koruma Yönetmeliği m 3/1(f) uyarınca geçici koruma; ülkesinden ayrılmaya zorlanmış, ayrıldığı ülkeye geri dönemeyen, acil ve geçici koruma bulmak amacıyla kitlesel olarak veya bu kitlesel akın döneminde bireysel olarak sınırlarımıza gelen veya sınırlarımızı geçen ve uluslararası koruma talebi bireysel olarak değerlendirmeye alınamayan yabancılara sağlanan koruma olarak tanımlanmıştır.

82 Geçici Koruma Yönetmeliği, Yönetmelik Numaras1: 2014/6883, Kabul Tarihi: 13.10.2014, RG 22.10.2014729153.

83 Geçici koruma müessesesi, mülga 1994 tarihli İltica ve Göç Yönetmeliği’nin 8 ila 26. maddeleri arasında, "geçici koruma” kavramı kullanılmaksızın, sınırlarımıza topluca gelen veya sınırlarımızı topluca geçen yabancılara yapılacak işlemler ve alınacak tedbirlere ilişkin hükümler kapsamında düzenlenmiştir. Ekşi, Yabancllar Hukuku (n 77) 55.

${ }^{84}$ Madde metninin, Türk yabancılar hukukunda uluslararası korumanın kapsamı ve türleri dikkate alınmaksızın hazırlandığını belirterek mevcut halini eleştirmekle birlikte; Türkiye'nin 1951 Cenevre Konvansiyonu'na koyduğu coğrafi sınırlama sebebiyle MÖHUK'un 4. maddesinde yer alan "mülteci”" kavramını "sığınmacıları" (şartlı mültecileri) da kapsayacak şekilde genişletmenin mümkün olmadığı ve bu sebeplerle MÖHUK m 4/1(a)'nın sadece Avrupa'da cereyan eden olaylar sebebiyle "mülteci" statüsü alanlara uygulanabileceğine ilişkin aksi görüş için bkz Nuray Ekşi, Yargıtay Kararları Işığında Milletlerarası Miras Hukuku (Beta 2013) 37-38.
} 


\section{(1) MÖHUK m 4/1(a)'nın Gerekçesinin Değerlendirilmesi}

MÖHUK m 4/1(a) hükmünün konuluş amacını (ratio legis) belirlerken öncelikle başvurulması gereken kaynak madde gerekçesidir. Madde gerekçesinde; 5718 sayılı MÖHUK'un 4. maddesinin (a) bendine "mülteciler" ibaresinin eklenmesindeki ${ }^{85}$ amacın, “(...) MÖHUK uyarınca milli hukukun uygulanması gereken hallerde, vatandaşlıkları olsa bile, o ülkenin diplomatik himayesinden çeşitli nedenlerle yararlanamayan kişilere, Türkiye'de kaldikları süre içerisinde yapacakları veya muhatap olduklart işlemlerde, milli hukuk yerine uygulanacak hukukun ne olduğunu göstermek" olduğu ifade edilmiştir ${ }^{86}$.

Her ne kadar madde gerekçesinde açıkça kullanılmamış olsa da, "vatandaşlı̆̆ olmakla birlikte, vatandaşl olduklarl ülkeyi terk eden ve bu ülkenin diplomatik himayesinden yararlanamayan veya yararlanmak istemeyen kişiler" uluslararas1 belgelerde fiili vatansız kavramıla ifade edilmektedir. Hukuki vatansız ise, uluslararası belgeler ve YUKK m 3(ş) bendinde "vatansız" olarak ifade edilen, "hiçbir devlete vatandaşlık bağıyla bağlı bulunmayan kişi”" $\mathrm{dir}^{87}$. Tanımdan da anlaşılacağ üzere, fiili vatansı kavram1, 1951 Cenevre Konvansiyonu m 1 ve YUKK m 61 anlamında "mülteci" kavramını da kapsayan daha geniş bir kavramdır. 1951 Cenevre Konvansiyonu ve YUKK anlamında tüm "mülteciler", ya hukuki veya fiili vatansız olmakla birlikte; tüm fiili vatansızlar, "mülteci" olarak kabul edilmemektedir. Bununla birlikte; MÖHUK m 4/1(a) hükmünün gerekçesinde, madde metnindeki "mülteci” ibaresiyle fiili vatansızların kastedildiği açıklanmıştır. Bu itibarla, kanaatimizce, MÖHUK m 4/1(a) hükmünde "mülteciler" ibaresi, 1951 Cenevre Konvansiyonu ve YUKK'taki dar anlamıyla değil; "vatandaşı olduğu ülkenin diplomatik himayesinden çeşitli nedenlerle yararlanamayan" tüm fiili vatansızları kapsayacak şekilde geniş

${ }^{85}$ Belirtilmelidir ki, 5718 sayılı MÖHUK ile yürürlükten kaldırılan 1982 tarihli ve 2675 sayılı mülga MÖHUK m 4/1(a)'da, sadece "vatansızlar"'n milli hukukunun ne şekilde tayin edileceği düzenlenmekte idi. "mülteciler" ibaresi madde metnine 5718 sayılı MÖHUK'un kabulüyle eklenmiştir. Bu sebeple, 5718 sayılı MÖHUK m 4/1(a)'nın madde gerekçesinde, madde metnine "mülteciler" ibaresinin eklenmesindeki amaç ve bu ifadeden ne anlaşılması gerektiği ayrıntılı bir şekilde açıklanmıştır.

86 MÖHUK Tasarısı Madde Gerekçeleri, Madde 4, Başbakanlık Kanunlar ve Kararlar Genel Müdürlüğ̈, 7/7/2006 <https:// www2.tbmmgov.tr/d23/1/1-0337.pdf> Erişim Tarihi 11 February 2020.

87 BM Genel Sekreterliği’nin vatansız kişilerle ilgili 1949 tarihli "Vatansızlık Çalışma Raporu”nda; “vatansızlar”, "hukuki vatansızlar" (stateless persons de jure) ve "fiili vatansızlar" (stateless persons de facto) olmak üzere ikiye ayrılmaktadır. Bkz UN, 'A Study of Statelessness' (1949) 7<https://www.refworld.org/pdfid/3ae68c2d0.pdf> Erişim Tarihi 11 February 2020. 1949 tarihli Rapora göre; "hukuki vatansızlar", "hiçbir devlete vatandaşlık bağı ile bağlı olmayan kişiler"dir. Türkiye'nin 2014 yılında taraf olduğu, 1954 tarihli "Vatansız Kişilerin Statüsüne İlişkin BM Sözleşmesi”nin (Convention Relating to the Status of Stateless Persons) 1. maddesinin 1. fikrasında "vatansız" kavramı, "kendi yasalarının işleyişi içinde hiçbir devlet tarafindan vatandaş olarak sayılmayan kişi” şeklinde tanımlanmıştır. (Sözleşme metni için bkz RG 25.10.2014/29156). YUKK m 3(ş) bendinde de "vatansız", "hiçbir devlete vatandaşlık bağıyla bağlı bulunmayan kişi " olarak tanımlanmıştır. Dolayısıyla 1954 tarihli Vatansız Kişilere İlişkin BM Sözleşmesi ve YUKK'ta "vatansız” kavramı ile kastedilen, hukuki vatansızlardır. 1949 tarihli "Vatansızlık Çalışma Raporu”na göre "fiili vatansızlar" ise, "vatandaşlığı olmakla birlikte, vatandaşı oldukları ülkeyi terk eden ve bu ülkenin diplomatik himayesinden yararlanamayan veya yararlanmak istemeyen kişiler”dir. Aynı tanım, BM Uluslararası Mülteci Örgütü'nün (International Refugee Organization-IRO) 20 Ağustos 1948 tarihinde yürürlüğe giren ve 31 Aralık 1951 tarihinde, BM Mülteciler Yüksek Komiserliği'nin kurulması ile feshedilen "Uluslararası Mülteci Örgütü Anayasası"nın 1 numaralı Ekinin 1. Kısmının A Bölümünün 2. fikrasında yer alan "mülteci" tanımında da benimsenmiştir. Bkz International Refugee Organization, Constitution of the International Refugee Organization, 62 Stat. 3037, Treaties and Other International Act Series 1846. Bu itibarla, MÖHUK m 4/1(a) hükmünün gerekçesinde kullanılan “mülteci” tanımı, BM Genel Sekreterliği’nin ve Uluslararası Mülteci Örgütü’nün fiili vatansız tanımı ile örtüşmektedir. 
anlamıyla kullanılmıştır. Dolayısıyla MÖHUK m 4/1(a) hükmüne “mülteci” ibaresinin eklenmesindeki amaç esasen, hukuki vatansızların yanında fiili vatansızların da "milli hukukları" yerine uygulanacak hukuku netleştirmektir.

Ayrıca, MÖHUK m 4/1(a)'nın gerekçesinde, yabancının, vatandaşı olduğu ülkenin diplomatik himayesinden yararlanamama sebebinin, "çeşitli nedenlerle" olabileceği ifade edilmiştir. 1951 Cenevre Konvansiyonu ve YUKK m 61'deki dar anlamıyla "mülteci" tanımında ise, kişinin haklı zulüm korkusunun ve ülkesinin diplomatik himayesinden yararlanamamasının sebepleri, "1rk1, dini, tabiiyeti, toplumsal gruba mensubiyeti veya siyasi düşünceleri”" şeklinde sayılarak sınırlandırılmıştır. MÖHUK m 4/1(a) gerekçesinde "çeşitli nedenlerle" denilerek, böyle bir sınırlamanın getirilmemiş olması; kanaatimizce, 1951 Cenevre Konvansiyonu ve YUKK'ta sayılan sebepler dışında başka herhangi bir sebeple ülkesinin diplomatik himayesinden yararlanamayan veya yararlanmak istemeyen ve ülkesinden ayrılmış her yabancının (fiili vatansızın) hükmün kapsamına dâhil edilmek istendiğini göstermektedir.

MÖHUK m 4/1(a)'nın gerekçesinde, herhangi bir coğrafi kısıtlamadan da bahsedilmemiş aksine; "mülteciler" ibaresinin madde metnine, 1951 Cenevre Konvansiyonu'nun 12. maddesinde ${ }^{88}$ bu konuda aynı mealde bir hüküm bulunmakla birlikte, “(...) sözleşmeye katılmamış olan ülkelerden gelen mültecilerin durumunun da düzenlenmesinin gerekli olduğu düşüncesiyle” eklendiği ifade edilmiştir. Böylelikle aslında, 1951 Cenevre Konvansiyonu'na konan coğrafi sınırlamanın, MÖHUK m 4/1(a) hükmü bakımından dikkate alınmaması ve dünyanın neresinden gelirse gelsin Türkiye'de bulunan fiili vatansızların Türkiye'de gerçekleştirecekleri işlemlerde milli hukuklarındaki belirsizliğin çözüme kavuşturulması amaçlanmıştır. Nitekim doktrinde de, 1951 Cenevre Sözleşmesi'nin 12. maddesindeki Sözleşme’ye tabi mültecilerin şahsi statüsüne ilişkin özel düzenlemenin yanında; MÖHUK m 4/1(a)'da ayrıca bir düzenleme getirilmesinin asıl amacının, Türkiye bakımından 1951 Cenevre Sözleşmesi haricinde kalan, "şartlı mülteci", "ikincil koruma" ve "geçici koruma statüsü sahipleri” gibi koruma statülerine sahip kişilerin şahsi statülerinin belirlenmesi olduğu ifade edilmektedir. Bu nedenlerle, bizim de katıldığımız görüşe göre, MÖHUK m 4/1(a)'da yer alan mülteciler ibaresinin, geçici koruma statüsü sahibi Suriyeliler de dâhil olmak üzere, YUKK'ta düzenlenen tüm koruma statülerini kapsayacak şekilde geniş yorumlanması gerekmektedir ${ }^{89}$.

\footnotetext{
8 Gerekçede sehven 1951 Cenevre Konvansiyonu'nun 22. maddesi denmiş olup, esasen 12. maddesi kastedilmiştir.

${ }^{89}$ Aynı yönde bkz Tekinalp ve Uyanık (n 69$) 63$ fn. 25; Şanlı, Esen ve Ataman-Figanmeşe (n 69) s. 32 fn. 60; Çelikel ve Erdem (n 69) 69; Burcu İrge Erdoğan, '5718 Sayılı MÖHUK Uyarınca Tenkis Davasında Uygulanacak Hukukun Kamu Düzeni Bakımından Değerlendirilmesi ve Yetkili Mahkeme’ (2018) 20(1) DEÜHFD 397, 403.
} 


\section{(2) 1951 Cenevre Konvansiyonu'nun 12. Maddesinin Gerekçesinin Değerlendirilmesi}

MÖHUK m 4/1(a) hükmünün gerekçesinin yanı sıra, madde metnindeki "mülteciler" ibaresinin kapsamını belirlerken, hükmün konuluş amacını ve böyle bir hükme neden ihtiyaç duyulduğunu tam anlamıyla kavrayabilmek için, madde gerekçesinde sözü edilen ve hükmün esinlenildiği 1951 Cenevre Konvansiyonu'nun 12. maddesinin hazırlık çalışmalarında cereyan eden tartışmalara ve Konvansiyon şerhine de kısaca göz atmakta yarar vardır.

1951 Cenevre Konvansiyonu'nun 12. maddesinin 1. fikrası uyarınca90, “her mültecinin bireysel statüsü, daimi ikametgahının bulunduğu ülkenin yasalarına veya ĕger daimi ikametgahı yoksa, bulunduğu ülkenin yasalarına tabidir"91. 1951 Cenevre Konvansiyonu, hukuken vatansiz olan mülteciler (de jure stateless refugees) ile bir vatandaşlığa sahip mültecilerin (de facto stateless refugees) şahsi statülerine uygulanacak hukukta, kendisinden önceki milletlerarası belgelerde benimsenen ayrımı ortadan kaldırarak; tüm “mülteci”lerin “şahsi statüsü”nü yerleşim yeri, yoksa bulundukları ülke hukukuna tabi kılmıştır"

Konvansiyon şerhinde, 1951 Cenevre Konvansiyonu'nun 12. maddesinin temel amac1; bir vatandaşlığa sahip olsun olmasın, tüm "mülteci”lere, koruma talep ettikleri ülkede gerçekleştirdikleri “şahsi statü”lerine ilişkin işlem ve ilişkilerde, zulme uğrama korkusu ile terk ettikleri “menşe ülkelerinin hukukunun uygulanmaması"nın temini

90 1951 Cenevre Konvansiyonu m 12/1: "The personal status of a refugee shall be governed by the law of the country of his domicile or, if he has no domicile, by the law of the country of his residence".

91 Konvansiyon hükmünün MÖHUK m 4/1(a)'dan farkı; "mutad mesken" bağlama noktasının yer almaması ve kuralın bağlama konusunun "mültecilerin" "şahsi statüsü" (personal status) olarak ifade edilmiş olmasıdır. Konvansiyon'da hangi meselelerin "şahsi statü”den sayılacağı ise bilinçli olarak açıklanmamış, taraf devletlerin iç hukuklarına bırakılmıştır. Konvansiyon'un hazırlık çalışmalarına bakıldığında; Sekretaryanın Taslak 12. madde metninin 2. fikrasında, “şahsi statü”ye dahil olup olmadığı tartışmalı görülen, aile hukuku (özellikle evlenme ve boşanma) ve miras hukukuna ilişkin meselelerde şekil, ehliyet ve yetkinin yerleşim yeri, yoksa sakin olunan ülke hukukuna tabi kılınarak, bu meselelerin de “şahsi statü”nün kapsamına dahil edilmesi yönünde bir düzenleme önerildiği; ancak tartışmalarda, hangi meselelerin “şahsi statü”ye dahil olacağı hususunda taraf devletlerin her birinin iç hukukunda farklı vasıflandırmalar yapılabileceğinden bu fikranın madde metninden çıkarıldığı ve "şahsi statü”ye dair meselelerin neler olduğunun her bir devletin iç hukukuna bırakıldığı görülmektedir. UNHCR, 'The Refugee Convention 1951: The Travaux préparatoires analysed with a Commentary by Dr. Paul Weis' (1990) 64-66, 80 <https://www.refworld.org/docid/53e1dd114.html> Erişim Tarihi 11 February 2020; Nomer (n 69) 118. BM Genel Sekreterliği'nin 1949 tarihli "Vatansızlık Çalışma Raporu”nda ise “şahsi statü”ye dair meseleler; (a) ehliyet (erginlik yaşı, evlenme ehliyeti, evli kadınların ehliyeti, fiil ehliyetinin sınırlandırılması ve sona ermesi vb.); (b) aile hukukundan kaynaklanan haklar (evlat edinme, evlenme, boşanma, velayet vb.); (c) akdi borç ilişkilerine ilişkin bir mesele olarak vasıflandırılmadıkça mal rejimleri ve (d) miras meseleleri olarak sayılmıştır. Bkz UN 'A Study of Statelessness' (n 87) 18. Türk milletlerarası özel hukukunda; ehliyet, vesayet ve hacir, gaiplik, nişanlanma, evlenme, boşanma ve ayrılık, soybağı, evlat edinme, velayet, vesayet ve kayyımlık gibi şahsı yakından ilgilendiren konular ile menkul miras prensip olarak "şahsi statü"ye dahil meseleler olarak görülmektedir. Nomer (n 69) 113. MÖHUK m 4/1(a) hükmünde ise, "şahsi statü” kavramı kullanılmamış; MÖHUK uyarınca yetkili hukukun vatandaşlık esasına göre tayin edildiği tüm hallerde söz konusu kuralın uygulama alanı bulacağı belirtilmiştir.

9230 Haziran 1928 tarihli "Rus ve Ermeni Mültecilerin Hukuki Durumuna Dair Anlaşma'da (Legal Status of Russian and Armenian Refugees)", 4 Temmuz 1936 tarihli "Almanyadan Gelen Mültecilerin Hukuki Durumuna Dair Geçici Sözleşme (The Provisional Agreement concerning The Status of Refugees Coming from Germany)" 4 . maddesinde ve 10 Şubat 1938 tarihli "Almanyadan Gelen Mültecilerin Hukuki Durumuna Dair Konvansiyon (Convention concerning The Status of Refugees Coming from Germany)” 6. maddesinde; mültecilerin "şahsi statüsü’ne uygulanacak hukuk düzenirken, "hukuki vatansız mülteciler" ile "vatandaşlığı olan (fiili vatansız) mülteciler" arasında ayrım yapılmış ve "hukuki vatansız" mülteciler hakkında, yerleşim yeri yoksa bulundukları ülke hukukunun; "vatandaşlığı olan (fiili vatansız) mülteciler" hakkında ise, milli hukuklarının uygulanacağı yönünde düzenlemeler getirilmiştir. 
olarak ifade edilmiştir ${ }^{93}$. Zira ister hukuki vatansız ister fiili vatansız olsun, mülteciler, vatandaşı oldukları veya önceki ikametleri olan menşe ülkelerini terk etmiş, o ülke ile bağlarını koparmış ve o ülkenin diplomatik korumasından artık yararlanmayan kişilerdir. Ayrıca mülteciler, genellikle menşe ülkelerindeki ayrımcılıktan kaçan kişiler olduklarından, mültecilere, vatandaşı oldukları veya önceki ikametleri olan menşe devletinin hukukunun uygulanmasının, çoğu zaman (özellikle, menşe devlette bu kişilerin ehliyeti bakımından sınırlandırıcı hükümler var ise) mültecilerin menfaatine olmayabileceğine de dikkat çekilmiştir ${ }^{94}$.

Diğer taraftan, Konvansiyon şerhinde, hükmün gerekçelerinden biri olarak, mültecilerin bir vatandaşlığının olup olmadığının veya bir vatandaşlığı olduğunu iddia ettiği durumlarda gerçekten o ülkenin vatandaşı olup olmadığının tespitindeki zorluklara da işaret edilmiştir ${ }^{95}$. Gerçekten de bu kişilerin, vatandaşlık ve şahsi statülerine ilişkin bilgi ve kayıtlarına (nüfus kayıtları, medeni hallerini gösteren kayıtlar vb.), vatandaşı oldukları menşe ülke ile iletişime geçerek ulaşmaya veya doğrulatmaya çalı̧̧mak çoğu durumda mülteci bakımından risk yaratabilecektir. 1951 Cenevre Konvansiyonu'nu imzalayan bütün ülkeler, kendi sınırları içerisinde mültecileri koruma ve onlara uluslararası standartlara uygun şekilde davranma yükümlülüğü altındadır. Kaldı ki, bu kişilerin vatandaşı oldukları menşe devlete şahsi statüleri ile ilgili bilgiler sorulsa dahi, menşe devletin bu kişilere karşı hasmane tutumundan ötürü, bilgileri paylaşmama olasılığının yüksek olduğu da Konvansiyonun hazırlık çalışmalarındaki tartışmalarda ifade edilmiştir ${ }^{96}$.

Ayrıca Konvansiyon şerhinde, ister hukuki ister fiili vatansız olsun tüm mültecilerin milli hukukunun tespitindeki belirsizliklere net bir çözüm getiren bu hükmün, iltica devletinin vatandaşları ve mahkemeleri bakımından sağlayacağı avantajların da altı çizilmiş̧ir. Buna göre; iltica devleti vatandaşlarının, mültecilerle olan hukuki işlem ve ilişkilerinde, öngörebilecekleri bir hukukun (çoğu durumda iltica devletinin hukuku olarak kendi milli hukuklarının) uygulanacak olmasından ötürü, bu işlem ve ilişkileri kurmakta çekimser davranmayacakları; iltica devletinin mahkemelerinin de, mültecilerin şahsi statülerine ilişkin uyuşmazlıklarda, uygulanacak hukuku bulma ve yabanc1 hukukun muhtevasını tespit etme gibi zor bir görevden kurtulacakları ifade edilmiştir ${ }^{97}$. Bu bağlamda, Konvansiyonun hazırlık çalışmalarındaki tartışmalarda, Türkiye heyeti tarafindan, normal şartlarda bir devlette nispeten daha az sayıda yabancı bulunmasına nazaran; yüzlerce, binlerce mültecinin bir ülkede bulunması

\footnotetext{
3 Konvansiyon şerhinde, mültecinin “yerleşim yeri”nin tespitinde de, bu amaç göz önünde bulundurularak, mültecinin vatandaşı olduğu menşe ülke hukukunun uygulanmasından kaçınılması gerektiği ve ayrıca atıf (renvoi) uygulamasının da dışlandığı özellikle vurgulanmıştır. Bkz UNHCR ‘The Refugee Convention 1951: The Travaux préparatoires’ (n 91) 79.

94 Bu bağlamda, özellikle Alman Yahudilerinin fiil ehliyetlerini pek çok bakımdan kısıtlayan Nürnberg yasaları örnek gösterilmiştir. Bkz UNHCR 'The Refugee Convention 1951: The Travaux préparatoires' (n 91), 66, 79.

95 UNHCR ‘The Refugee Convention 1951: The Travaux préparatoires' (n 91) 65.

96 UNHCR 'The Refugee Convention 1951: The Travaux préparatoires' (n 91) 66.

${ }_{97}$ UNHCR 'The Refugee Convention 1951: The Travaux préparatoires' (n 91) 65.
} 
durumunda, bu kişilerin her birinin vatandaşlıklarının tespiti, milli hukuklarının tespiti ve nihayetinde milli hukukları olarak yabancı bir hukukun uygulanmasının, koruma devleti mahkemelerinin altından kalkamayacağı bir iş yükü yaratabileceğinin de altı çizilmiştir ${ }^{98}$. Nitekim milyonlarca Suriyelinin Türkiye'de koruma altında olduğu günümüzde, Türkiye heyetinin bu öngörüsü gerçekleşmiş durumdadır.

Netice olarak, 1951 Cenevre Konvansiyonu'nun 12. maddesinin konuluş amacina ilişsin hazırlık çalışmaları ve Konvansiyon şerhinde ifade edilen bu mülahazaların tümü, vatandaşı olduğu ülkenin diplomatik himayesinden yararlanamayan tüm fiili vatansızlar bakımından geçerlidir. Sadece 1951 Cenevre Konvansiyonu'nun 12. maddesinin kişi bakımından uygulama alanı, Konvansiyon'un 1. maddesindeki dar mülteci tanımı ve Türkiye bakımından Konvansiyona konmuş olan coğrafi kısıtlama sebebiyle sinırlıdır.

\section{(3) Kanaatimiz}

Kanaatimizce, 1951 Cenevre Konvansiyonu'nun 12. maddesiyle benzer gerekçe ve mülahazalarla kaleme alınmış olan MÖHUK m 4/1(a) hükmünün getirilme sebebi, Konvansiyondaki kişi ve yer itibariyle uygulama alanına ilişkin sınırlamaları aşmak ve dünyanın neresinden gelirse gelsin, çeşitli nedenlerle vatandaşı olduğu ülkenin diplomatik himayesinden yararlanamayan tüm fiili vatansızların Türkiye'de gerçekleştirecekleri işlemlerde milli hukuku yerine hangi hukukun uygulanacağını göstermektir ${ }^{99}$.

Aksi yönde bir yorumla, sırf Türkiye'nin Konvansiyona koyduğu coğrafi kısıtlama sebebiyle şartlı mültecileri ve dar mülteci tanımındaki kriterlere uymadığı için ikincil koruma altındakileri hükmün kapsamı dışında bırakmak, hükmün ratio legisi ile bağdaşmayacaktır ${ }^{100}$.

Aynı şekilde, acil ve geçici koruma bulmak amacıyla kitlesel akınla sınırlarımıza gelen geçici koruma altındaki Suriyelileri de, bireysel statü belirleme işlemlerinin yapılamaması ve korumanın geçici bir süreyle sağlanması sebebiyle, hükmün uygulama alanı dışında bırakmak hükmün ratio legisiyle bağdaşmayacaktır. Zira geçici koruma altındaki kişiler de, vatandaşı oldukları menşe devleti terk etmiş ve o ülkenin diplomatik himayesinden yararlanamayan veya yararlanmak istemeyen kişilerdir. Bu kişileri, uluslararası koruma statüsü sahiplerinden ayıran tek şey; kitlesel akın ile gelmeleri ve bu kitlesel akın karşısında iltica devletinin, bireysel uluslararası koruma başvuru prosedürlerini yürütebilecek ve değerlendirebilecek kapasitesinin bulunmaması nedeniyle, durumun aciliyeti de göz önünde bulundurularak,

\footnotetext{
UNHCR 'The Refugee Convention 1951: The Travaux préparatoires' (n 91) 66.

99 Aynı yönde bkz Tekinalp ve Uyanık (n 69) 63-64; Şanlı, Esen ve Ataman-Figanmeşe (n 69) 32 dn 60

100 Aksi yönde bkz Ekşi, Milletlerarası Miras (n. 84) 37-38.
} 
korumanın geçici olarak verilmesidir. Esasen bu kişilerin sığınma ve korunma ihtiyacı ve MÖHUK 4/1(a)'nın amacı bakımından, vatandaşlıklarındaki belirsizliğin giderilmesi ihtiyacı, bireysel başvuru ile mülteci, şartlı mülteci veya ikincil koruma statüsü verilen uluslararası koruma statüsü sahiplerinden farklı değildir. Ayrıca, geçici koruma statüsü, bir süreyle sınırlı olarak bahşedilen geçici bir statü olmakla birlikte; MÖHUK m 4/1(a) hükmünün konuluş amac1 dahilinde, statünün geçici veya kalıcı olması bir kriter değildir. Zira MÖHUK m 4/1(a) hükmü zaten, koruma sahibinin Türkiye'de iken yaptığı hukuki işlem ve ilişkilere uygulanacaktır. Kaldı ki, bir uluslararası koruma statüsü olarak şartlı mülteci statüsü de, kiş̧i, güvenli bir üçüncü ülkeye yerleştirilinceye kadar verilen geçici bir statüdür (YUKK m 62). Bu itibarla, koruma statüleri arasında böyle bir ayrım yapmak hükmün konuluş amacı ile bağdaşmayacağı gibi; statünün kalıcı veya geçici olması hükmün uygulamasında da herhangi bir farkl1lık veya mahzur yaratmayacaktır ${ }^{101}$.

Nitekim Yargıtay'ın da yerleşik içtihatlarında isabetli olarak, MÖHUK m 4/1(a) hükmünde yer alan "mülteciler" ibaresini geniş anlamılla yorumladığı ve Türkiye tarafindan kendisine 6458 sayılı YUKK'ta yer alan koruma statülerinden birisi sağlanmış tüm kişilere uyguladığı görülmektedir. Örneğin; Yargıtay 2. Hukuk Dairesi, 08.02.2010 tarihli kararında, Türkiye'de "şartlı mülteci" statüsünde olan Afgan uyruklu eşler arasındaki boşanma davasında, MÖHUK m 14 uyarınca, boşanmaya uygulanacak "müşterek milli hukuk" un belirlenmesinde, MÖHUK m 4/1(a) bendine atıfta bulunarak, "şartlı mülteci" eşlerin vatandaşlığının "mültecilere" uygulanan MÖHUK m 4/1(a) uyarınca tespit edilmesi gerektiği yönünde karar vermiştiri102.

$\mathrm{Bu}$ sebeplerle, kanaatimizce, MÖHUK m 4/1(a)'nın geçici koruma altındaki Suriyeliler de dahil olmak üzere, YUKK'ta öngörülen tüm koruma statülerini (mülteci, şartlı mülteci ve ikincil koruma) kapsayacak şekilde yorumlanması gerekmektedir. Bununla birlikte; MÖHUK m 4/1(a) hükmünün uygulama alanının belirlenmesinde doktrin ve uygulamada yaşanan tereddütleri ortadan kaldırmak adına, hükümde bir değişiklik yapılarak, "mülteci" kavramı yerine, "vatandaşı olduğu ülkenin diplomatik himayesinden yararlanamaması sebebiyle koruma talep eden veya sağlanan kişiler"

\footnotetext{
101 MÖHUK m 4/1(a) hükmünün, uluslararası koruma statüsü sahipleri hakkında uygulanması gerektiği; ancak geçici korumada, bireysel başvuru ile bir statü belirleme işlemi söz konusu olmadığından ve bu statünün geçici bir durum için kullanıldığından, geçici koruma statüsü sahipleri hakkında uygulanamayacağı yönündeki aksi görüş için bkz Ayşe Kübra Altıparmak, İngiliz, Avrupa Birliği ve Türk Hukukunda Mirasa Uygulanacak Hukuk (Oniki Levha 2017) 112.

102 Yargıtay 2 HD, 19552/2037, 08.02.2010. Aynı yönde başka bir karar için bkz Yargıtay 2 HD, 13194/1781, 24.01.2013 (Kararlar için bkz <www.lexpera.comtr $>$ Erişim Tarihi 21 February 2020).
} 
ifadesinin getirilmesinin de yerinde olacağı kanaatindeyiz ${ }^{103}$. Böylelikle, Türk iç hukuk mevzuatında ileride tekrar değişme ihtimali bulunan dar kavramlardan kaçınılarak daha geniş ve kapsayıcı bir ifade kullanılmış olacak ve madde metni konuluş amacı ile uyumlu bir hale kavuşacaktır ${ }^{104}$.

\section{c. MÖHUK m 4/1(a) Hükmünün Geçici Koruma Altındaki Suriye Vatandaşlarına Uygulanması}

Türkiye'de geçici koruma altında bulunan Suriyelilerin MÖHUK m 4/1(a) hükmü kapsamında "milli hukuku"nun tespitinde, hükmün zaman itibariyle uygulama alanının belirlenmesi de önem taşımaktadır.

Maddegerekçesinde, hükmün, vatandaşı oldukları̈̈lkenin diplomatik himayesinden çeşitli nedenlerle yararlanamayan kişilere, “(...) Türkiye'de kaldıkları süre içerisinde yapacakları veya muhatap oldukları işlemlerde" uygulanacağı ifade edilmiştir ${ }^{105}$. Bu itibarla, MÖHUK m 4/1(a) hükmü, sadece, madde kapsamındaki yabancıların "Türkiye'de kaldıkları süre içerisinde yaptıkları veya muhatap oldukları işlemlerde" uygulanabilecek ve bu işlemlerde milli hukukları yerine, yerleşim yeri, mutad mesken veya dava tarihinde bulundukları ülke hukuku olarak Türk hukukunun uygulanması söz konusu olabilecektir. Bu kişilerin Türkiye'ye gelmeden önce gerçekleştirdikleri işlemlerde "milli hukuk"larını uygularken ise, MÖHUK m 4/1(a) hükmü uygulama alanı bulmayacağından, bu bent uyarınca Türk hukukuna gidilemeyecek; vatandaşı oldukları devletin hukuku uygulanacaktır.

\footnotetext{
${ }_{103}$ MÖHUK m 4/1(a) hükmünün, meri Türk yabancılar hukuku mevzuatı göz önünde bulundurularak yeniden düzenlenmesi gerektiği yönünde bkz Ekşi, Milletlerarası Miras (n 84) 38. Ekşi’nin önerisi ise, bizimkinden farklı olarak, hükme, "uluslararası koruma talep eden veya uluslararası koruma sağlanan yabancılar" ibaresinin eklenmesi yönündedir. Belirtilmelidir ki; "geçici koruma" da esasen bir "uluslararası koruma" sağlama aracı olduğundan ve Ekşi de eserinde, "geçici korumayı" bir "uluslararası koruma" başlığı altında ele aldığından, bu öneri ile amaçlanan, geçici koruma statüsü sahiplerini MÖHUK m 4/1(a) kapsamından dışlamak değil; aksine hükmün geçici korumaya da uygulanmasını temin etmektir. Ne var ki; YUKK'ta "uluslararası koruma" kavramı dar bir şekilde tanımlanmış ve "geçici koruma" bir "uluslararas koruma" türü olarak sayılmamıştır (YUKK m 3/1(r)). YUKK'un "uluslararası koruma" kavramına "geçici koruma"yı dâhil etmeyen bu düzenlemesi karşısında, kanaatimizce, MÖHUK m 4/1(a) hükmüne yönelik değişiklikte "uluslararası koruma" kavramının kullanılması, "geçici koruma"nın hüküm kapsamına dahil olup olmadığı konusunda tereddütlere ve yeni tartışmalara yol açabilecektir. Bu nedenle, çalışmamızda, MÖHUK m 4/1(a) hükmüne yönelik değişiklikte, YUKK terminolojisinden bağımsız olarak, uluslararası koruma arayan tüm kişileri kapsamına alacak "vatandaşı olduğu ülkenin diplomatik himayesinden yararlanamayan kişi” "ifadesinin kullanılması önerilmiştir.

104 İsviçre hukukuna bakıldığında, MÖHUK m 4/1(a)'ya benzer bir hüküm olarak, IPRG Art 24/3 uyarınca; "vatansız ve mülteciler bakımından, vatandaşlık yerine yerleşim yeri uygulanacaktır" hükmü yer almaktadır. "Vatansız" kavramı ise, IPRG Art 24/1'e göre; "Bir kişi, 1954 tarihli New York Sözleşmesi uyarınca vatansız ise veya vatandaşı olduğu ülke ile vatandaşlık bağı vatansızlı̆̆a eşdeğer seviyede zayıflamışsa, bu kişi vatansızdır” şeklinde tanımlanmıştır. Bu itibarla, İsviçre milletlerarası özel hukukunda, 1954 tarihli Sözleşme uyarınca hukuki vatansızlar ile İsviçre İltica Kanunu uyarınca mülteciler yanında, fiili vatansızlar da, açıkça IPRG Art 24 hükmüne dâhil edilmiştir. Alman hukukunda ise, aynı konu, EGBGB Art 5/2'de; "Bir kişi vatansızsa veya vatandaşlı̆̆ tespit edilemiyor ise, mutad mesken mesken hukuku, yoksa bulunduğu ülke hukuku uygulanır" şeklinde düzenlenmiştir. "Vatandaşlığı tespit edilemeyen kişiler" olarak fiili vatansızları işaret eden bu hüküm kapsamında vatandaşlığın tespit edilip edilemediğinin belirlenmesi, kanaatimizce, uygulamada zorluklara sebebiyet verebilecek ve uygulanacak hukukun belirlenmesi aşamasını uzatabilecektir. Bu sebeple, kanaatimizce, koruma talep eden tüm fiili vatansızların hükmün kapsamına dahil olduğuna ilişkin İsviçre hukukundaki gibi açık bir düzenleme yapılması daha yerinde olacaktır.

105 MÖHUK Tasarısı Madde Gerekçeleri, Madde 4 (n 86).
} 
Netice olarak, kanaatimizce, MÖHUK m 4/1(a) hükmü uyarınca, geçici koruma altındaki Suriyelilerin, Türkiye'de kaldlkları süre içerisinde yaptıkları işlemlerde, milli hukuklarının uygulanması gereken konularda, yerleşim yeri, mutad mesken veya dava tarihinde bulundukları devlet hukuku olarak Türk hukukunun uygulanması gerekmektedir.

\section{Geçici Koruma Altındaki Suriye Vatandaşlarının Çocuk Yaşta Evliliklerinin Geçerliliğine Uygulanacak Hukuk}

MÖHUK m 4/1(a) hükmüne ilişkin tüm bu açıklamalarımız ışığında; geçici koruma altındaki Suriyelilerin Türkiye'de iken gerçekleştirdikleri evliliklerin, MÖHUK m 13/1 uyarınca evlenme ehliyet ve şartları bakımından geçerliliğine ve dolayısıyla evlenme yaşına, "eşlerden her birinin evlenme anındaki milli hukuku" olarak, Suriyeli eş bakımından, MÖHUK m 4/1(a) gereği Türk hukuku uygulanmalıdır.

Nitekim İçişleri Bakanlığı Nüfus ve Vatandaşlık İşleri Genel Müdürlüğü de, 13.10.2015 tarihli ve "Mülteciler ve Geçici Koruma Altına Alınanların Evlenme ve Çocuklarının Tanınması" konulu yazısında, isabetli bir biçimde, 6458 sayılı YUKK'un 61, 62, 63 ve 91. maddelerine göre mülteci, şartlı mülteci, ikincil koruma statüsünde bulunan ve geçici koruma altına alınanların, MÖHUK m 13/1 uyarınca "milli hukukları"na tabi olan evlenme ehliyet ve şartları ile evlenme engelleri konusunda, MÖHUK m 4/1(a) bendine atıfta bulunarak, Türk hukukunun esas alınacağını kararlaştırmış ve ilgili kamu kurumlarına iletmiştir ${ }^{106}$.

Türk hukukunda evlenme yaş1, 4721 sayılı Türk Medeni Kanunu'nun ${ }^{107}$ (TMK) 124. maddesinin 1. fikrası uyarınca, erkek ve kadın için 17 yaş olarak belirlenmiştir. Buna göre, erkek ve kadın 17 yaşını tamamlayıp, 18 yaşından gün almakla evlenme yaşına erişmiş olmaktadır. Bununla birlikte; 17 yaşını doldurmuş olup henüz ergin olmayanlar (başka bir sebeple ergin olunmamışsa 18 yaşını doldurmayanlar), ancak yasal temsilcilerinin izniyle evlenebilmektedirler (TMK m 126). Bununla birlikte, TMK m 124/II'de olağanüstü evlenme yaşı da düzenlenmiştir. Hâkim olağanüstü durumlarda ve pek önemli bir sebeple, olanak var ise karardan önce anne, baba veya vasiyi dinleyerek, 16 yaşını doldurmuş olan erkek veya kadının evlenmesine izin verebilmektedir. Dolayısıyla, Türk hukukunda olağan evlenme yaşı, kadın ve erkek için, 17; olağanüstü evlenme yaşı ise, 16 yaştır. Türk Medeni Kanunu'nda asgari evlenme yaşı olan 16 yaşını doldurmamış bir kişinin yaptığı evlilik ise, doktrinde tartışmalı olmakla birlikte, Yargıtay'ın yerleşik içtihatlarına göre, "yok hükmünde"

\footnotetext{
106 İçişleri Bakanlığı Nüfus ve Vatandaşlık İşleri Genel Müdürlüğü, Sayı: 40004962-010.07.01-E.88237, Tarih: 13.10.2015.

107 Türk Medeni Kanunu, Kanun Numaras1: 4721, Kabul Tarihi: 22.11.2001, RG 08.12.2001/24607.
} 
kabul edilmektedir ${ }^{108}$. Bu itibarla, geçici koruma altındaki Suriyelilerin Türkiye’ye geldikten sonra yaptıkları evliliklerde, Suriyeli eş bakımından, olağan evlenme yaşı 17, olağanüstü evlenme yaşı ise 16 yaş olarak aranacak ve buna göre İl Göç İdaresi Müdürlüklerince evlenme ehliyet belgesi düzenlenecektir ${ }^{109}$.

Geçici koruma altındaki Suriyelilerin Türkiye’ye gelmeden önce gerçekleştirdikleri
evlilikler bakımından ise; MÖHUK m 4/1(a) bendi uygulama alanı bulmayacağından, MÖHUK m 13/1 uyarınca evlenme yaşına, Suriyeli eş bakımından, "eşlerden her birinin evlenme anındaki milli hukuku" olarak vatandaşı olduğu Suriye hukukunun uygulanması gerekecektir ${ }^{110}$. Suriye hukukunda evlenme yaşı, 1953 tarihli Suriye Kişisel Durumlar Kanunu'nda (SKDK) düzenlenmiştir ${ }^{111}$. SKDK m 15 uyarınca,

108 Evlenme yaşını tamamlamadan gerçekleștirilmiş evliliklerin hükmü Türk hukukunda tartışmalıdır. Zira Türk Medeni Kanununda evlenme yaşı tamamlanmadan yapılmış evliliklerin müeyyidesi, mutlak butlan (TMK m 145) ve nisbi butlan (TMK m 148-151 ve m 153) sebepleri arasında sayılmamıştır. Bu durum, doktrinde farklı görüşlere yol açmıştır. Ayrıntılı bilgi ve görüşler için bkz Keskin (n 13) 71 vd. Doktrinde baskın görüş, evlenme yaşı tamamlanmadan gerçekleștirilmiş evliliklerin geçersiz olduğu yönündedir. Ancak bu geçersizliğin türü ve gerekçesi hususlarında görüș ayrılıkları mevcuttur. Birinci görüş; evlenme yaşı tamamlanmadan yapılan evliliklere, bir nisbi butlan sebebi olarak TMK m 153’te düzenlenen yasal temsilcinin izninin bulunmamasına ilişkin hükmün kıyasen uygulanması yönündedir. (Bkz Selahattin Sulhi Tekinay, Türk Aile Hukuku (7. Bas1, Filiz Kitapevi 1990) 146-147; Akıntürk ve Karaman (n 67) 225). İkinci görüş; evlenme için öngörülen asgari yaşa gelmemiş olanların evlenme hakkına sahip olmamaları sebebiyle, kanuna aykırılıktan bu evliliklerin mutlak butlanla batıl olması gerektiği yönündedir (Dural, Öğüz ve Gümüş (n 67) 48, 53). Üçüncü görüş; kanun koyucunun asgari evlenme yaşı için bir faraziyeden hareket ettiğini ve olağanüstü evlenme yaşı olan 16 yaşı tamamlamamış kişilerin evlenme için gerekli ayırt etme gücüne sahip olmadıklarını kabul ederek, TMK m 145/2 uyarınca evlenmenin mutlak butlanla batıl olduğunu savunmaktadır (Bkz Kemal Oğuzman ve Mustafa Dural, Aile Hukuku (2. Bası, Filiz Kitapevi 1998) 67; Hüseyin Hatemi ve Rona Serozan, Aile Hukuku (Filiz Kitapevi 1993) 111; Keskin (n 13) 76 vd). Dördüncü görüşe göre; butlan kararından önce, olağanüstü evlenme yaşı olan 16 yaşa ulaşılmış ancak olağan evlenme yaşı olan 17 yaşa ulaşılmamışsa, olağanüstü evlenmede hâkim izni olmadan evlenme yapıldığı için bu evlenmeler, mutlak butlanla batıl sayılmalıdır. Butlan kararı verilmeden önce 17 yaşına ulaşılııșa, bu evlenmeler nisbi butlanla batıl sayılmalıdır. Butlan kararı verilmeden kişi 18 yaşına varıp ergin olur veya karı gebe kalırsa, evlenmenin iptaline karar verilememelidir (Bkz Ömer Uğur Gençcan, Aile Mahkemesi Davaları (2. Bası, Yetkin Yayınları 2016) 94). Yargıtay'ın yerleşik içtihatlarında benimsenen beşinci görüşe göre ise; olağanüstü evlenme yaşı olan 16 yaşını doldurmamış bir kimsenin yaptığı evlilik, evlenmenin kurucu unsurlarından birisi olan yaş şartının eksikliği sebebiyle "yok evlenme" hükmündedir. Bu görüşe göre; mutlak butlan ve nisbi butlan sebeplerinin Kanunda sınırlı olarak sayılmış olması karşısında, ortaya çıkabilecek sakıncalara rağmen, 16 yaşını tamamlamamış olanlarca yapılan evliliklerin yok hükmünde olduğunun kabulü gerekmektedir. (Bkz Öztan (n 67) 138-139). Aynı yönde Yargıtay kararları için bkz Yargıtay 2 HD, 4235/7649, 03.05.2011; Yargıtay 2 HD, 4315/5370, 14.04.2003; Yargıtay 2 HD, 6049/14441, 30.10.2006 (Kararlar için bkz Gençcan (n 108) 93).

109 Evlendirme Yönetmeliği m 13/2 uyarınca; 6458 sayılı Yabancılar ve Uluslararası Koruma Kanunu kapsamındaki yabancılardan; ikamet izni dışında Türkiye'de bulunan vatansız, mülteci, şartlı mülteci, ikincil koruma statüsünde bulunanlar ve uluslararası koruma başvuru sahipleri ile geçici koruma kapsamına alınan yabancıların evlenme manilerinin bulunup bulunmadığı, il göç idaresi müdürlüklerince tutulan dosyalarındaki bilgi ve belgelere göre il göç idaresi müdürlüklerince tespit edilir ve evlenme ehliyet belgesi düzenlenir. Bkz Evlendirme Yönetmeliği, BK Kararı Numarası: 85/9747, BK Kararı Tarihi: 10.07 .1985 , RG 07.11.1985/18921.

110 MÖHUK m 2/3 uyarınca, aile hukukuna ilişkin meselelerde uygulanacak hukukun tespitinde "atıf" kabul edildiğinden; MÖHUK m 13/1 uyarınca evlenme yaşına uygulanacak hukukun tayininde, Suriye hukukunun kanunlar ihtilafı kurallarının da dikkate alınması gerekmektedir. Suriye Kişisel Durumlar Kanunu'nda yer alan evlenmeye ilişkin hükümlerin, eşlerden birinin Suriye vatandaşı ve diğerinin yabancı ülke vatandaşı olduğu evlenmeler bakımından da uygulanacağ belirtilmektedir. Ayrıca Kanunun, medeni evlenmeyi esas alan yabancı devletlerde Suriye vatandaşları ve yabancılar tarafından yapılan medeni evlenmelere uygulanmayacağı ve bu evliliklerin tescil edilmeyeceği düzenlenmiş olsa da; Suriye dışında yapılan bu evlenmelerin, Suriye kamu düzenine aykırılık oluşturmadığı sürece genellikle Suriye'de tescil edilebildiği ifade edilmektedir. (Bkz Esther van Eijk, Family Law in Syria: Patriarchy, Pluralism and Personal Status Laws (IB Tauris, 2016) 53; LANDINFO, 'Report Syria: Marriage Legislation and Traditions' (2018) $8<$ https://landinfo.no/ wp-content/uploads/2018/10/Report-Syria-Marriage-legislation-and-traditions-22082018.pdf> Erişim Tarihi 21 February 2020; Daad Mousa, 'Syrian Personal Status Law' (Friedrich-Ebert-Stiftung 2018) $4<$ http://library.fes.de/pdf-files/bueros/ beirut/14969.pdf> Erişim Tarihi 21 February 2020). Bu hükümler çerçevesinde; Suriye kanunlar ihtilafı kurallarına göre de, evlenme ehliyet ve şartlarına Suriye hukukunun uygulanmasının öngörüldüğü sonucuna varılabilmektedir.

111 17.09.1953 tarihli Suriye Kişisel Durumlar Kanunu; evlenme, boşanma, velayet, vesayet ve nafaka gibi kişisel durumlarla ilgili hükümleri düzenlemektedir. Ayrıntılı bilgi için van Eijk (n 110) 49-51; LANDINFO Report Syria (n 110) 7). Ayrıca bkz OLG Bamberg, Beschluss vom 12.05.2016 - 2 UF 58/16, para. 20; BGH, Beschluss vom 14.11.2018 - XII ZB 292/16, para 11. 
evliliğe uygun olmak için akıllı ve buluğa erişmiş olmak şarttır. Evlenme yaşı ise; SKDK m 16 uyarınca, erkek için 18 yaş, kadın için 17 yaş olarak belirlenmiştir. Bununla birlikte, SKDK m 18 uyarınca, 15 yaşını doldurmuş erkek çocuğu veya 13 yaşını doldurmuş kız çocuğu, buluğa erdiğini iddia eder ve evlenme talebinde bulunursa, iddialarının doğruluğuna ve bedenlerinin evliliği kaldırabileceğine kanaat eden hâkim, yapılmış veya yapılacak olan dini evlenmenin (örfi evlilik) tesciline onay verebilmektedir. Hâkimin evlenmenin tesciline onay verebilmesi için, küçüğün babasının veya büyükbabasının muvafakati gerekmektedir ${ }^{112}$. Suriye hukukunda asgari evlenme yaşı olarak öngörülmüş 13 yaşını tamamlamamış kız çocukları veya 15 yaşını tamamlamamış erkek çocukları tarafından yapılan evliliklere bağlanan hukuki sonuç ise; iptal edilebilirliktir ${ }^{113}$.

112 van Eijk (n 110) 216-217; LANDINFO Report Syria (n 110) 11. Ayrica bkz OLG Bamberg, Beschluss vom 12.05.2016 - 2 UF 58/16, para 21; BGH, Beschluss vom 14.11.2018 - XII ZB 292/16, para 12. Suriye hukukunda, medeni hukuk ve islami şeri hukuk hükümleri birarada uygulanmaktadır (çoklu hukuk sistemi). Buna göre, Müslümanlar bakımından evlenme, "örfi evlilik" (zawaj urfi) olarak adlandırılan dini nikahın kıyılması ile yapılmakta ve bu nikahın Şeriat mahkemelerinde tescili ile evlilik resmiyet kazanmaktadır. Suriye hukukuna göre; medeni evlilik mümkün değildir. Diğer taraftan; SKDK m 40 uyarınca; dini nikahın kıyılmasından (örfi evlilik) ve fiilen evlilik başlamadan (eşler birlikte yaşamaya başlamadan) önce veya dini nikahın kıyılmasından ve fiilen evliliğin başlamasından çok sonra da, mahkemeye başvurularak evlenmenin tescili mümkündür (Bkz van Eijk (n 110) 49-53, 144; LANDINFO Report Syria (n 110) 7-9, 23). Dini nikahın kıyılmasından sonra evlenmenin geç tescilinde (tathbit al-zawaj), evlenme tarihi olarak, eşlerin ve iki şahidin sözlü beyanları ile bildirdikleri tarih esas alındığından, geçmiş bir tarihin bildirilmesi mümkündür. Bu durumda, evlenmenin tescili ile, evlilik, bu belirtilen tarihten itibaren geçmişe yönelik olarak resmiyet kazanmaktadır. (Bkz van Eijk (n 110) 218; LANDINFO Report Syria (n 110) 10). Bu itibarla; SDDK m 18 hükmünde, kanuni evlenme yaşı olan erkek için 18 yaş ve kız çocukları için 17 yaşını doldurmadan yapılan evlenmelerin tescili bakımından hakim onayı gerektiği düzenlenmiş ise de; esasen burada bahsedilen onay, evliliğin kurulmasına ilişkin değil, tescili suretiyle resmiyet kazanmasına ilişkindir. Kaldı ki; kanuni evlenme yaşına uygun olarak yapılmış evlilikler bakımından da, evlenmenin resmiyet kazanması için tescil gerekmektedir. Kanuni yaş şartını doldurarak yapılan evlilikler ile doldurmadan yapılan evlilikler arasındaki tek fark, Şeriat hakiminin tescili reddetme imkanına ilişsindir. Dolayısıyla, Suriye hukukunda, hakim onayı olmaksızın, kanuni evlenme yaşını doldurulmadan yapılan dini evlilikler (örfi evlilikler) geçersiz kabul edilmemekte ve eşler, medeni kanundaki yaş şartını doldurduktan sonra Şeriat mahkemelerine başvurarak evliliklerini tescil ettirdiklerinde, evlilikleri, geçmişe etkili olarak resmiyet kazanmaktadır. Ayrıca, Suriye hukukunda, SDDK m 40 uyarınca, kadın gebe kalmış veya doğum yapmış ise, evlenme şartları yerine getirilmemiş olsa dahi, evlenmenin tescilinin redddedilmesinin mümkün olmadığı düzenlenmiştir. (Bkz van Eijk (n 110) 218; LANDINFO Report Syria (n 110) 10). Bu kapsamda, uygulamada; 13 yaşın altında olup gebe kalmış olan kız çocuklarının örfi evliliklerinin de Şeriat hakimlerince tescil edildiği kaydedilmektedir (Bkz LANDINFO Report Syria (n 110) 12; Mousa (n 110) 4). Bu sebeple, gerek evlenmenin geç tescili mekanizmasına gerekse gebe kalma halinde tescilin reddedilememesine ilişkin düzenlemeler çerçevesinde, Suriye hukukunda, SDDK m 18'de düzenlenen kız çocukları için asgari yaş şartı olan 13 yaşın altında evlenmenin de mümkün olduğu görülmektedir. İslam hukukunda evlilik ve evlenme yaşı hakkında ayrıntılı bilgi için ayrıca bkz Nuray Ekşi, Milletlerarası Özel Hukukta Medenî Olmayan Evliliklerin ve Adlî Olmayan Boşanmaların Tanınması (Beta 2012) 10-11.

113 Suriye hukukunda, sadece, bir Müslüman ile bir gayrimüslim arasında yapılan evlilikler yok hükmünde kabul edilmektedir (SKDK m 48/2). (Bkz van Eijk (n 110) 64-65; LANDINFO Report Syria (n 110) 8; Mousa (n 110) 4). Suriye hukukunda, mehir ödemesi, kardeşler arası evlilik yasağı ve boşanma veya ölüm halinde kadının iddet müddetine ilişkin hükümler de bulunmaktadır. Bunlar dışında, bir kadın ve erkeğin evlenme iradeleri tam ise ve mehir ödenmişse, evliliğin hükümsüzlüğüne yol açacak herhangi bir sebep düzenlenmemiştir (SDDK m 51/2) (Bkz van Eijk (n 110) 215; LANDINFO Report Syria (n 110) 8). Dolayısıyla, bir Müslüman ve gayrimüslimin evlenmiş olması ve mehirin ödenmemiş olması dışında, evlilikteki herhangi bir sakatlık sadece bu evliliğin iptal edilebilir olmasına yol açmaktadır (SDDK m 47-51). Bu itibarla, Suriye hukukunda asgari evlenme yaşına iliş̧in hükümlerin ihlal edilmesi halinde, Suriye hukukuna göre, "iptal edilebilir" bir evlilik söz konusudur. Bkz OLG Bamberg, Beschluss vom 12.05.2016 - 2 UF 58/16, para 25; BGH, Beschluss vom 14.11.2018 - XII ZB 292/16, para 15. Suriye hukukunda, asgari evlenme yaşının altında yapılan örfi evlenmelerde "iptal edilebilirliğin" türünün, "mutlak butlan" mı yoksa "nisbi butlan" $\mathrm{m}$ olduğu hususunda ise bir açıklık bulunmamaktadır. Bununla birlikte; örfi evliliklerin Şeriat mahkemesince tescilinde, hakimin, Suriye Kişisel Durumlar Kanunu'nda aranan evlenme şartlarını re'sen kontrol ettiği ve eşler arasındaki yaş farkının çok fazla olması veya evlenmenin eşlerin yararına (maslaha) olmayacağına kanaat getirmesi halinde, evliliğin tescilini reddedebileceği ifade edilmektedir (SDDK m 18-19). (Bkz van Eijk (n 110) 216; LANDINFO Report Syria (n 110) 11). Bu bağlamda, eşlerin veya onların yasal temsilcilerinin iptal talebi olmaksızın, bir kamu makamı olarak Şeriat mahkemelerinin re'sen evliliğin tescilini reddetmek suretiyle iptaline karar verebilmesi bakımından, kanaatimizce, buradaki iptal edilebilirliğin türü "mutlak butlan" olarak nitelendirilmelidir. Ancak belirtilmelidir ki; SDDK m 40 uyarınca, kadın gebe kalmış veya doğum yapmış ise, evlenme şartları yerine getirilmemiş olsa dahi, evlenmenin tescilinin reddi suretiyle iptali mümkün değildir. (Bkz van Eijk (n 110) 218; LANDINFO Report Syria (n 110) 10). 
Görüldüğü üzere, MÖHUK hükümleri uyarınca, geçici koruma altındaki Suriyelilerin Türkiye'de bulundukları süre içerisinde 16 yaşlarını tamamlamadan evlilik yapmaları mümkün değildir; yapsalar dahi bu evlenmeler yok hükmünde sayılır. Ancak Türkiye'ye gelmeden önce yaptıkları evlenmeler Suriye hukukuna tabi olacağından, 16 yaşını doldurmadan (hatta kız çocukları için 13 yaşını dahi doldurmadan) evlilik yapmış olmaları mümkündür. Peki bu durumda 13 veya 14 yaşında bir Suriyeli kız çocuğu tarafından Türkiye'ye gelmeden önce yapılmış bir evlilik MÖHUK m 13 uyarınca Suriye hukukuna göre geçerli bir evlilik ise Türk hukukuna göre de geçerli sayılacak mıdır? Türk hukukunda olağanüstü evlenme yaşının 16 yaş olarak öngörülmesi ve 16 yaş altı evliliklerin Yargıtayca "yok" hükmünde olduğunun kabul edilmesi karşısında; bu sorunun cevabı, kız çocuklarının 13 yaşında evlenmesine müsaade eden Suriye hukuku hükümlerinin uygulanmasının somut sonucu olarak böyle bir evliliğin tanınmasının MÖHUK m 5 uyarınca Türk kamu düzenini açıkça ihlal edip etmediğinin tespitine bağlı olacaktır ${ }^{114}$.

\section{B. Geçici Koruma Altındaki Suriye Vatandaşlarının Çocuk Yaşta Yaptıkları Mevcut Evliliklerin Geçerliliğine Suriye Hukukunun Uygulanması}

MÖHUK hükümleri çerçevesinde, geçici koruma altındaki Suriyelilerin Türkiye'ye gelmeden önce yaptıkları evliliklerde evlenme yaşına Suriye hukukunun uygulanması, çocuk yaşta yapılmış evlenmelerin tanınmasının Türk kamu düzenine aykırılık oluşturup oluşturmayacağ 1 ve dolayısıyla böyle evliliklerin Türk hukukunda geçerli sayılıp sayılmayacağ 1 meselesini beraberinde getirmektedir. Ancak buna geçmeden önce, Türk hukukunda özellikle mahkeme uygulamasında, yabancı hukuk olarak Suriye hukukunun temini ile ilgili yaşanan problemlere değinilecektir.

\section{Yabancı Hukukun Uygulanması Bakımından Suriye Hukukunun Temini ve Uygulanması}

Türk mahkemelerinde kanunlar ihtilafı kuralları uyarınca yetkili yabancı hukukun uygulanmas1, 5718 sayılı MÖHUK'un 2. maddesinde düzenlenmiştir. Buna göre; Türk kanunlar ihtilafı kurallarına göre yetkili kılınan “yabancı hukuk”un hâkim tarafindan re'sen uygulanma mecburiyeti vardır. Bu sebeple, kanunlar ihtilafı kuralları uyarınca yabancı hukukun uygulanacağı durumlarda, hâkimin doğrudan kendi hukukunu, Türk

\footnotetext{
SDDK m 40 uyarınca, kanuni evlenme yaşı doldurulmadan ve hakimin evliliğin tesciline ilişkin onayı olmaksızın yapılan örfi evlilikler de, evliliğin geç tescili usulü (tathbit al-zawaj) ile geçmişe yönelik olarak resmiyet kazanabildiğinden; hakim onayı ile tescil edilmeksizin kanuni evlenme yaşının altında gerçekleştirilen örfi evlilikler, resmiyet kazanmamış olmakla birlikte, Suriye hukukuna göre geçerli evliliklerdir (bkz yukarıda (n 112). Diğer taraftan, SDDK m 18 hükmünde sözü edilen hakim onayı, esasen evlenme işleminin tesciline yönelik olmakla, tanıma ve tenfize tabi olabilecek bir mahkeme kararı niteliği taşımamaktadır (bkz yukarıda (n 112). Bu sebeplerle, Suriye hukukuna göre kanuni evlenme yaşının altında gerçekleştirilen çocuk yaşta evliliklerin Türk hukukuna göre geçerliliği, evliliğin hakim onayı ile tescil ettirilmiş olup olmadığından bağımsız olarak, MÖHUK m 5 hükmü uyarınca "Türk kamu düzenine aykırılık" kapsamında incelenmiştir.
} 
hukukunu uygulaması, kanunlar ihtilafı kurallarının ve dolayısıyla Türk hukukunun açık ihlalini oluşturur ${ }^{115}$.

Türk hâkimi, yabancı hukuku re’sen uygulama yükümlülüğü kapsamında; yabancı hukuku re'sen temin edecek, muhtevasını araştıracak ve olaya tatbik edecektir. Yabancı hukukun tatbiki, tarafların veya taraflardan birinin talebine bağlı değildir ${ }^{116}$. Yetkili yabancı hukukun muhtevasının tespitinde MÖHUK $m$ 2/1'in 2. cümlesinde ifade edilen "taraf yardımı", hâkimin yabancı hukukun muhtevasını re'sen bulma ve tatbik etme görevini ortadan kaldırmamakta; sadece hâkime, bu yolda başvurabileceği ek bir imkân sunmaktadır. Yetkili yabancı hukukun muhtevasının tespitinde, taraf yardımı yanında, hâkimin başvurabileceği diğer yollar ise; Türkiye'nin taraf olduğu "1968 tarihli Yabanc1 Hukuk Hakkında Bilgi Edinilmesine Dair Avrupa Sözleşmesi”"17'ne, Adalet Bakanlığ1 Uluslararası Hukuk ve Dış İlişkiler Genel Müdürlüğü’ne, “bilirkişilik” kurumuna, "hukuki mütalaa" usulüne ve üniversitelere başvurudur.

Hâkim, yetkili yabancı hukukun olaya uygulanacak hükümlerini tüm araştırmalarına rağmen tespit edemezse, MÖHUK m 2/2 uyarınca Türk hukukunu uygulayacaktır. Ancak bu hüküm, hâkimin yukarıda sayılan tüm yollara başvurması ve tüketmesi ve buna rağmen yabancı hukuku temin edemediği hallerde geçerlidir. Teknolojik telekomünikasyon araçlarının oldukça gelişmiş olduğu günümüzde, yabanc1 hukukun muhtevasının temin edilememesi pek mümkün görünmemektedir. Bununla birlikte; Suriye ile Türkiye Cumhuriyeti arasında günümüzde olduğu üzere, hukuku uygulanacak yabancı devlet ile diplomatik ilişkilerin kesilmiş olması sebebiyle, yabancı hukuk kurallarının diplomatik veya resmi yollardan temin edilememesi durumları ile karşılaşılabilir. Ancak, bu halde dahi, diplomatik veya resmi yollar dışındaki; taraf yardımı, bilirkişilik, hukuki mütalaa veya üniversitelerden bilgi alma gibi yollarla yabancı hukuka ulaşılması mümkün olabilir ${ }^{118}$. Bu nedenle, MÖHUK m 2/2 uyarınca Türk hukukunun uygulanabilmesi için, hâkimin, diplomatik ve resmi kanallar dışındaki bu usullere başvurması ve buna rağmen yabancı hukukun ilgili hükümlerini tespit edememesi gerekmektedir ${ }^{119}$.

\footnotetext{
115 Nomer (n 69) 201; Şanlı, Esen ve Ataman-Figanmeşe (n 69) 60-61; Çelikel ve Erdem (n 69) 175-176; Doğan, Milletlerarası Özel Hukuk (n 69) 247-248. Yargıtay’ın, yabancılık unsuru dikkate alınmaksızın, kanunlar ihtilafı kurallarına başvurmadan, doğrudan Türk hukukuna göre davanın karara bağlanmasını bozma sebebi yaptı̆̆ı kararları için bkz Yargıtay 2 HD, 13685/14841, 04.11.2003; Yargitay 2 HD, 14069/15890, 28.12.2004; Yargitay 18 HD, 2899/4027, 21.04.2005 (Kararlar için bkz <www.lexpera.com.tr> Erişim Tarihi 21 February 2020).

116 Nomer (n 69) 192; Şanlı, Esen ve Ataman-Figanmeşe (n 69) 63-64; Çelikel ve Erdem (n 69) 171-172; Tekinalp ve Uyanık (n 69) 46; Doğan, Milletlerarası Özel Hukuk (n 69) 240-241. Kanunlar ihtilafı kurallarına göre yetkili yabancı hukukun tatbikinde hakimin, tarafların talep ve itirazları ile bağlı olmadığı yönünde Yargıtay kararları için bkz Yargıtay 11 HD, 5344/5910, 16.09.1997 (<www.lexpera.comtr> Erişim Tarihi 21 February 2020); Yargıtay 2 HD, 2722/2613, 11.03.1967 (<www.kazanci.com> Erişim Tarihi 21 February 2020)

117 European Convention on Information on Foreign Law (RG 26.08.1975/15338). Ayrıca Yabancı Hukuk Hakkında Bilgi Edinilmesine Dair Avrupa Sözleşmesi'nin uygulanması hakkında, Adalet Bakanlığı Uluslararası Hukuk ve Dış İlişkiler Genel Müdürlüğü’nün 67/1 sayılı ve 01.03.2008 tarihli Genelgesi için bkz <http://www.diabgm.adalet.gov.tr/arsiv/ genelgeler/67.1.pdf $>$ Erişim Tarihi 21 February 2020.

118 Nomer (n 69) 196-197; Şanl1, Esen ve Ataman-Figanmeşe (n 69) 71-72; Çelikel ve Erdem (n 69) 174-175; Tekinalp ve Uyanık (n 69) 46; Doğan, Milletlerarası Özel Hukuk (n 69) 245-246.

119 Resmi ve diplomatik kanallar dışındaki yollardan da yabancı hukuk hükümlerinin temin edilebileceği yönündeki örnek Yargıtay kararları için bkz Yargıtay 12 HD, 22462/24968, 14.12.2005; Yargıtay 11 HD, 5344/5910, 16.09.1997 (Kararlar için bkz <www.lexpera.comtr> Erişim Tarihi 21 February 2020).
} 
Zira kanunlar ihtilafi kurallarının yetkili kıldığı yabancı hukukun uygulanması, milletlerarası hukuktan kaynaklanan bir mecburiyet değil; "milletlerarası özel hukuk hakkaniyetini" gerçekleştirme bilincine, daha açık bir ifadeyle, mahkeme önündeki dava bakımından Türk hukukuna nispetle yabancı hukukun tatbik edilmesinin daha doğru ve adaletli olduğu anlayışına dayanmaktadır ${ }^{120}$. Bu nedenle; Türk milletlerarası özel hukukunda, yabancı bir devlet hukukunun uygulanmasının, uluslararası hukuk anlamında mütekabiliyet şartına tabi olmadığı kabul edilmektedir ${ }^{121}$.

Bu itibarla; geçici koruma altındaki Suriyeliler tarafından Türkiye'ye gelmeden önce yapılmış evlenmelerin geçerli olup olmadığının tespitinde, MÖHUK m 13/1 uyarınca Suriye hukukunu uygulamak durumunda olan Türk hâkiminin, mevcut durumda, Suriye ile Türkiye arasındaki diplomatik ilişkilerin kesilmiş olması sebebiyle, diplomatik ve resmi kanallardan (Adalet Bakanlığı veya Dişişleri Bakanlığı'ndan) Suriye hukukunun ilgili hükümlerinin temin edememesi halinde; taraf yardımı, bilirkişilik, hukuki mütalaa veya üniversitelerden bilgi alma gibi yollara başvurarak Suriye hukukunu temin etmeye çalışması gerekmektedir. $\mathrm{Bu}$ yolllara başvurmaksızın, Suriye hukukuna ulaşılamadığı gerekçesiyle MÖHUK m 2/2 uyarınca Türk hukukunun uygulanması Türk hukukunun açık ihlalini oluşturur ve temyiz sebebidir.

\section{2. Çocuk Yaşta Yapılan Mevcut Evliliklerin Geçerliliğine Suriye Hukukunun Uygulanmasında Türk Kamu Düzeni Müdahalesi}

Kanunlar ihtilafı kuralları uyarınca yetkili Suriye hukukunu ve muhtevasını temin eden Türk hâkimi, evlenme yaşına ilişkin Suriye Kişisel Durumlar Kanunu'ndaki hükümleri uygulayacaktır. Ancak Suriye hukukunda, 13 yaşını tamamlamış (hatta 13 yaşından da küçük) kız çocuklarının evlenmeleri mümkün kılınmıştır ${ }^{122}$. Bu itibarla, somut olayda, misalen, 14 yaşındaki bir kız çocuğu tarafindan Türkiye'ye gelmeden önce yapılmış bir evliliğin geçerliliğine Suriye hukukunu uygulamak durumunda olan Türk hâkiminin, Türk hukukunda olağanüstü evlenme yaşının 16 yaş olarak öngörülmüş olması karşısında, kız çocuklarının 13 yaşında evlenmelerine müsaade eden yabancı hukuk hükmünün olaya uygulanmasının somut sonucu olarak bu evliliğin tanınmasının MÖHUK m 5 kapsamında Türk kamu düzenini ihlal edip etmediğini değerlendirmesi gerekecektir.

\footnotetext{
120 Nomer (n 69) 189; Şanlı, Esen ve Ataman-Figanmeșe (n 69) 60; Faruk Kerem Giray, 'Milletlerarası Özel Hukuk Hakkaniyetinin 5718 Sayılı MÖHUK Kapsamında Değerlendirilmesi', (2011-2012) 8(9) YÜHFD (Prof. Dr. Erhan Adal'a Armağan) 555, 559; Doğan, Milletlerarası Özel Hukuk (n 69) 239.

121 Giray (n 120) 559; Şanl1, Esen ve Ataman-Figanmeşe (n 69) 67; Doğan, Milletlerarası Özel Hukuk (n 69) 238.

122 Bkz yukarıda (n 112).
} 


\section{a. Genel Olarak Türk Kamu Düzenine Aykırılık Müdahalesi}

MÖHUK m 2/1 uyarınca, hâkimin kanunlar ihtilafı kuralları uyarınca yetkili yabancı hukuku uygulaması görevi gereğidir ve kuraldır. Ancak mutlak değildir. Yabancı hukukun somut olaya uygulanması için, somut olayda meydana getirdiği sonuçların Türk kamu düzenine aykırı olmaması gerekmektedir. Yetkili yabancı hukukun uygulanmasina engel olarak "kamu düzenine aykırılı"" müdahalesi, MÖHUK m 5'te düzenlenmiştir. Buna göre; "Yetkili yabancı hukukun belirli bir olaya uygulanan hükmünün Türk kamu düzenine açıkça aykırı olması hâlinde, bu hüküm uygulanmaz; gerekli görülen hâllerde, Türk hukuku uygulanır”.

MÖHUK m 5 gereğince, kamu düzenine aykırılık müdahalesinin devreye girebilmesi için, öncelikle yetkili yabancı hukukun ilgili hükümlerinin olaya uygulanması ve bu uygulama neticesinde Türk kamu düzenine "açıça" aykırı bir durumun ortaya çıkması gerekmektedir. Zira kural, yetkili yabancı hukukun uygulanmasıdır. Kamu düzenine aykırılık müdahalesi ise istisnaidir. Bu itibarla, kamu düzenine aykırılık müdahalesinin uygulanması bakımından, bir takım özel hukuk meselelerinin baştan "kamu düzeninden" olarak nitelendirilip kategorize edilerek, bu konularla ilgili yabancılık unsuru içeren ihtilaflarda yetkili yabancı hukuk uygulanmaksızın doğrudan Türk hukukunun uygulanması yanlıştır ${ }^{123}$.

Kamu düzenine aykırılık değerlendirmesinin yapılabilmesi için, yetkili yabancı hukukun ilgili hükmünün olaya uygulanması neticesinde ortaya çıkan somut sonuçlar Türk kamu düzenine aykırı olmalıdır. Bu bakımdan, her bir somut olayda, o olayın şartları çerçevesinde, yabancı hukukun uygulanmasının somut sonuçlarına bakarak, somut olay bazında bir değerlendirme yapılmalıdır. Bu itibarla, yabancı hukukta Türk hukukunda var olmayan bir müessesenin düzenlenmiş olması veya aynı konuda Türk hukukundan farklı bir hüküm öngörülmüş olması tek başına Türk kamu düzenine aykırılık olarak değerlendirilemez ${ }^{124}$. Nitekim Yargıtay'ın 10.02.2012 tarihli İBK'da da isabetli olarak; Türk hukukunun emredici kurallarına aykırı olan yabancı hukukun her zaman Türk kamu düzenine aykırı sayılamayacağı açıkça ifade edilmiştir ${ }^{125}$.

Ayrıca Türk kamu düzenine aykırılık, açıkça bir aykırılık olmalıdır. Açıkça aykırılıktan anlaşılması gereken, yetkili yabancı hukukun ilgili hükmünün olaya uygulanması neticesinde, Türk kamu düzenini tahammül edilemez bir şekilde ihlal

\footnotetext{
123 Şanlı, Esen ve Ataman-Figanmeşe (n 69) 85-89; Nomer (n 69) 171-172; Tekinalp ve Uyanık (n 69) 43; Akıncı ve Demir Gökyayla (n 69) 8-9; Doğan, Milletlerarası Özel Hukuk (n 69) 259.

124 Yargıtay 2 HD'nin 20.02.2017 tarihli kararında isabetli şekilde, Türk maddi hukukunda var olmayan ve Yargıtay kararlarında uzun yıllardır Türk kamu düzenine aykırı olarak telakki edilen yabancı hukuklarda yer alan "müșterek velayet"e ilișkin hükümlerin uygulanmasının Türk kamu düzenine aykırılık teşkil etmeyeceği karara bağlanmıştır. Bkz Yargıtay 2 HD, 15771/1737, 20.02.2017 (<www.lexpera.comtr> Erişim Tarihi 21 February 2020).

125 Bkz Yargitay IBK, 2010-1/2012/1, 10.02.2012 (<www.lexpera.comtr> Erişim Tarihi 21 February 2020).
} 
eden bir durumun ortaya çıkmasıdır ${ }^{126}$. Bu bakımdan, yetkili yabancı hukukun ilgili hükmünün somut olaya tatbik edilmesi neticesinde; Türk hukuk sisteminin toplumsal ve kişisel hak ve özgürlükleri koruyan temel prensipleri, Anayasanın temel ilkeleri ve toplumda geçerli olan örf-adet ve ahlak kuralları ile "açıkça" uyuşmayan ve bu değerleri tahammül edilemez bir şekilde ihlal eden sonuçların ortaya çıkması halinde, yabancı hukukun Türk kamu düzenini açıkça ihlal ettiğinden bahsedilebilecek ve Türk hukukunun uygulanması söz konusu olabilecektir.

Yabancı hukukun ilgili hükümlerinin somut olaya uygulanması neticesinde, Türk kamu düzenini tahammül edilemeyecek ağırlıkta ihlal ettiğinin değerlendirilebilmesi için, somut olaydaki maddi ilişkinin, ülke ile irtibatının bulunması şarttır. Her bir somut olayda, Türkiye ile irtibat arttıkça, Türk kamu düzenine aykırılık müdahalesi olasılığg da kaçınılmaz olarak artacaktır ${ }^{127}$. Bu nedenle, kamu düzenine aykırılık değerlendirmesinde, somut olaydaki tarafların veya diğer maddi unsurların Türkiye ile olan irtibatının yoğunluğu da dikkate alınmalı ve ona göre bir karar verilmelidir. Diğer taraftan belirtilmelidir ki; temel hak ve özgürlüklerin bahis konusu olduğu durumlarda, dava konusu işlem veya ilişki ile ülke arasında irtibatının bulunup bulunmaması bir önem taşımayacaktır ${ }^{128}$.

Kamu düzenine aykırılık kararı verirken göz önünde bulundurulması gereken bir diğer husus; kamu düzenine aykırılık müdahalesi neticesinde ortaya çıkan sonucun, Türk kamu düzeni kapsamında korunmak istenen meşru amaca hizmet etmesidir. Kamu düzenine aykırı sonuçlar yarattığı gerekçesiyle yabancı hukukun uygulanmamasının neticeleri, kamu düzenine aykırılık müdahalesi ile korunmak istenen menfaatten daha üst bir menfaatin ihlaline sebebiyet vermemelidir. Buna bir anlamda, kamu düzenine aykırılık müdahalesinde "ölçülülü̈k" değerlendirmesi de denebilir. $\mathrm{Bu}$ nedenle, kamu düzenine aykırılık değerlendirmesinin, somut olay bazında yapılması oldukça önemlidir. Hâkim her bir somut olayda, o olayın şartlarını değerlendirmeli ve yabancı hukuk kuralının somut olaya uygulanmasının neticelerinin Türk kamu düzenini açıkça ihlal ettiğine karar vererek Türk hukukunu uyguladığı durumda ortaya çıkan sonucun, somut olay bakımından korunması gereken daha üst bir menfaati ihlal edip etmediğine bakmalı ve bu anlamda somut olayda mağduriyetlere sebebiyet vermemelidir ${ }^{129}$.

\footnotetext{
26 Yargıtay'ın 10.02.2012 tarihli İBK'da kamu düzenine aykırılık; “(...) Türk hukukunun temel değerlerine, Türk genel adap ve ahlak anlayışına, Türk kanunlarının dayandığı temel adalet anlaylşına, Türk kanunlarının dayandiğı genel siyasete, Anayasada yer alan temel hak ve özgürlüklere, milletlerarası alanda geçerli ortak prensip ve özel hukuka ait iyi niyet prensibine dayanan kurallara, medeni toplulukların müştereken benimsedikleri ahlak ilkeleri ve adalet anlaylşının ifadesi olan hukuk prensiplerine, toplumun medeniyet seviyesine, siyasi ve ekonomik rejimine, insan hak ve özgürlüklerine aykırıllk (...)” şeklinde tanımlanmıştır. Bkz Yargıtay İBK, 2010-1/2012/1, 10.02.2012 (<www.lexpera.comtr> Erişim Tarihi 21 February 2020).

127 Nomer (n 69) 178; Şanl1, Esen ve Ataman-Figanmeşe (n 69) 79-80; Tekinalp ve Uyanık (n 69) 43; Doğan, Milletlerarası Özel Hukuk (n 69) 260-261.

128 Nomer (n 69) 175; Şanlı, Esen ve Ataman-Figanmeşe (n 69) 81.

129 Nomer (n 69) 175-176; Şanl1, Esen ve Ataman-Figanmeşe (n 69) 81-82.
} 
Yabanc1 hukukun ilgili hükümlerinin somut olaya uygulanması neticesinde, Türk kamu düzenini "açıkça", tahammül edilemez bir biçimde ihlal eden sonuçların ortaya çıkması halinde ise, MÖHUK m 5 uyarınca kamu düzenine aykırılık müdahalesi gereği, Türk kamu düzenini açıkça ihlal eden yabancı hukuk hükmü uygulanmayacak; yerine, gerekli görülen hallerde, Türk hukuku uygulanacaktır.

\section{b. Çocuk Yaşta Yapılan Evliliklerin Tanınmasında Türk Kamu Düzenine Aykırılık Müdahalesi}

Geçici koruma altındaki Suriyeliler tarafından Türkiye'ye gelmeden önce yapılmış çocuk yaşta bir evliliğin geçerliliğine Suriye hukuku uygulanırken, Suriye Kişisel Durumlar Kanunu'nda yer alan evlenme yaşına ilişkin hükümlerin uygulanmasının sonucu olarak böyle bir evliliğin tanınmasının Türk kamu düzenine açıkça bir aykırılık teşkil edip etmeyeceğine ve dolayısıyla Türk hukukuna göre bu evliliğe geçerlilik tanınıp tanınmayacağına ilişkin değerlendirmenin de, Türk kamu düzenine aykırılık müdahalesine ilişkin bu esaslar çerçevesinde yapılması gerekmektedir.

Öncelikle belirtmek gerekir ki; geçici koruma altındaki Suriyeliler, 2014 tarihli Geçici Koruma Yönetmeliği Geçici Madde 1'de geçici koruma statüsünün ilanı ile 28/04/2011'den bu yana Türkiye'ye kabul edilmektedir. Ayrıca geçici koruma statüsü süresiz şekilde ilan edilmiş olduğundan, Türkiye'ye gelmiş olanların veya gelecek olanların, kaç yıl daha Türkiye'de bulunacakları belli değildir. Gelmiş olanlar, Türkiye'de çalışmaya, okula gitmeye, kısacası bir hayat kurmaya başlamışlardır. $\mathrm{Bu}$ itibarla, kanaatimizce, geçici koruma altındaki Suriyelilerin taraf oldukları uyuşmazlıklarda, kamu düzenine aykırılık incelemesi bakımından, somut olayın maddi unsurlarının Türkiye ile yeterli bir ilişkinin bulunması şartı karşılanmaktadır.

Uygulamada; yabancılar tarafından yabancı hukuka göre yapılmış bir çocuk yaşta evliliğin geçerliliğinin Türk hukukunda tanınmasına ilişkin bir ihtilafın, Türk mahkemeleri önüne gelebilmesi; başkaca bir ihtilaf kapsamında önmesele teşkil etmesi haricinde, evliliği yapmış olanların kendileri, yasal temsilcileri veya ilgili kişilerce veyahut da vakanın tespiti üzerine resmi makamlarca açılacak bir iptal davas ${ }^{130}$ ile mümkün olacaktır. İptal davasında, yabancı hukuka göre yapılmış bir çocuk yaşta evlililiğin tanınmasının, Türk kamu düzenine açıça aykırılık teşkil edip etmediği ve bu itibarla Türk hukukuna göre geçerli olup olmadığının tespitinde, kanaatimizce, çocuk yaşta evlenmiş olanların, "dava anındaki", daha doğru bir ifadeyle, "evlenmenin tanınması anındaki” yaşlarına göre bir değerlendirme yapılması gerekir. Zira burada, yabancı hukuka göre geçerli olan bir evlenme işlemine Türk hukukunda geçerlilik tanınması söz konusudur.

\footnotetext{
130 Yabancı hukuka göre yapılmış çocuk yaşta evliliğin Türk kamu düzenine açıkça aykırılık oluşturduğunun tespiti halinde, bu evliliğin geçersizliğinin müeyyidesi ve sonuçlarına uygulanacak hukuka ve iptal edilebilirliğin türüne ilişkin açıklamalarımız için bkz aşağıda III(B)(2)(c).
} 
Bu kapsamda, MÖHUK m 5 uyarınca yapılan Türk kamu düzenine aykırılık incelemesinde de, somut olayın şartlarına göre bir değerlendirme yapılmakta ve somut olaydaki evliliği geçerli sayan yabancı hukuk hükümlerinin uygulanması sonucunda ortaya çıkan "somut sonuçların" Türk kamu düzenini ihlal edip etmediğine bakılmaktadır. Yoksa, yabancı hukuk hükmünün kendisinin Türk kamu düzenini ihlal edip etmediğine bakılmamaktadır. Çocuk yaşta evliliğe imkan veren yabancı hukukun uygulanmasının "somut sonuçları” ise, evliliğin Türk hukukunda tanınması ile ortaya çıkacak somut sonuçlardır. Bu çerçevede, Türk kamu düzenine aykırılık incelemesinin konusu, evliliğin tanınması ile bu kişilerin Türkiye'de evli sayılmalarının Türk kamu düzenini tahammül edilemeyecek derecede açık bir şekilde ihlal edip etmediğidir. Bu itibarla, Türk kamu düzenine aykırılık değerlendirmesi yabancı hukukun uygulanmasının somut sonuçları üzerinden yapıldığına göre, yabancı hukuka tabi çocuk yaşta evliliklerin tanınmasında, eşlerin, "tanıma (iptal davası) anındaki” yaş durumları esas alınmalıdı1'131.

Bu çerçevede, kanaatimizce, yabancı hukukta evlenme yaşına ilişkin hükümlerin uygulanmasının somut sonucu olarak, çocuk yaşta yapılmış bir evliliğin tanınmasının Türk kamu düzenine aykırılık teşkil edip etmediği değerlendirmesi, tanıma (iptal davası) anında eşlerden birinin 16 yaşını doldurmadığı evlilikler için yapılmalıdır. Zira Türk hukukunda, istisnai olarak, hâkim izniyle de olsa, 16 yaşını doldurmuş olanların evlenmelerine imkân tanınmaktadır (TMK m 124/II). $\mathrm{Bu}$ bağlamda, 16 yaşın tamamlanması ile evlenmeye müsaade eden bir yabancı hukuk kuralının uygulanmasının somut sonuçlarının tek başına, Türk kamu düzenine açıkça bir aykırılık yaratacağını kabul etmek mümkün gözükmemektedir. $\mathrm{Bu}$ değerlendirmemiz şüphesiz, somut olayda, zorla evlendirme gibi, Türk kamu düzenine açıkça aykırılık teşkil edebilecek ve evliliğin Türk hukukuna göre geçersiz olmasını sonuçlayabilecek başkaca bir etkenin bulunmadığı, sadece evlenme yaşının küçüklüğü sebebiyle Türk kamu düzenine aykırılık değerlendirmesinin yapıldığ 1 ve evliliğin geçerliliğinin tartışma konusu olduğu durumlar için geçerlidir. Bu itibarla, tanıma anında, eşlerden her ikisi de 16 yaşını doldurmuş ise ve somut olayda zorla evlendirme bulgusu yoksa, kanaatimizce, Türk kamu düzenine aykırılık sebebiyle böyle bir evlenmenin geçersiz olduğuna hükmedilmemelidir.

Türk hukukunda 16 yaşını doldurmadan yapılan evlilikler ise, Yargıtay içtihatları uyarınca "yok" hükmünde kabul edilmektedir. Dolayısıyla, geçici koruma altındaki Suriyelilerin Türkiye'ye gelmeden önce yaptıkları evliliklerin geçerliliği bakımından, Suriye hukukunun uygulanmasının somut sonucu olarak çocuk yaşta yapılmış bir evliliğin tanınmasının Türk kamu düzenine aykırılık teşkil edip etmediği

31 Nitekim BW Art 10:32'ye getirilen değişiklikle Hollanda hukukunda da; tanıma talebi anında her iki eşin de Hollanda hukukundaki asgari evlenme yaşı olan 18 yaşını doldurmuş olması halinde evlenmenin Hollanda'da tanınacağı hükme bağlanmakla, tanıma anındaki yaş durumlarının esas alınacağı açık hükme bağlanmıştır (BW Art 10:32:c). 
değerlendirmesi, tanıma (iptal davası) anında eşlerden en az birinin 16 yaşını doldurmamış olduğu hallerde yapılmalıdır ${ }^{132}$.

Tanıma anında, eşlerden birinin 16 yaşını doldurmamış olduğu durumda, 16 yaşın altında evlenmeye müsaade eden Suriye hukuku hükümlerinin uygulanması suretiyle böyle bir evliliğin tanınmasının somut sonuçlarının Türk kamu düzenine aykırılık teşkil edip etmediğine ilişkin değerlendirmede ise; kaç yaşına kadar küçüklerin evlenmelerinin Türk kamu düzenine açıkça aykırılık teşkil edeceğine ilişkin olarak bir yaş sınırı belirlemek kamu düzenine aykırılık müdahalesi yöntemi bakımından doğru değildir. Türk mahkeme tatbikatında, yabancı hukuka göre asgari kaç yaşına kadar yapılmış evlenmelerin tanınmasının Türk kamu düzenini açıkça ihlal ettiğine ilişkin herhangi bir Yargıtay içtihadı bulunmamaktadır. Alman mahkeme tatbikatına baktığımızda ise, farklı kararlar görmek mümkündür. Örneğin; Berlin Eyalet Yüksek Mahkemesi (Kammergericht) 2012 tarihli bir kararında, 14 yaşında bir Lübnan vatandaşı tarafından yapılan evliliğin Alman kamu düzenini ihlal ettiğine karar vermişken; Tübingen Bölge Mahkemesi (Amtsgerichte Tübingen) 1992 tarihli bir kararında, 14 yaşında bir Uruguay vatandaşı tarafından yapılan evliliğin Alman kamu düzenini ihlal etmediği ve yine yukarıda da bahsettiğimiz üzere, Alman Federal Mahkemesi (Bundesgerichtsof) 2018 tarihli kararında, 14 yaşında bir Suriye vatandaşı tarafından yapılan evliliğin Alman kamu düzenini ihlal etmediği yönünde karar vermiştir ${ }^{133}$. Bu nedenle, tanıma anında eşlerden birinin 16 yaşın altında olduğu yabancı hukuka göre yapılan evliliklerde, Türk kamu düzenine aykırılık bakımından asgari bir yaş sınırı çizilmemeli; her somut olayda o olayın şartlarına göre yabancı hukuk kuralının olaya uygulanması neticesinde evliliğin tanınması ile ortaya çıkan somut sonuçlar üzerinden bir değerlendirme yapılmalıdır ${ }^{134}$.

Çocuk yaşta evliliklerde kamu düzenine aykırılık değerlendirmesine ilişkin somut olay bazında değerlendirme yapılırken, göz önünde bulundurulması gereken en önemli husus ise, "çocuğun üstün menfaati”dir. "Çocuğun üstün menfaati ilkesi”" milletlerarası özel hukukta, çocuğa ilişkin her türlü uyuşmazlıkta kamu düzenine aykırılık değerlendirmesinde bir $\ddot{u}$ st norm olarak kabul edilmektedir ${ }^{135}$. Zira evlenme

132 Türk hukukundakinden daha küçük bir evlenme yaşı öngören yabancı hukukun uygulanmasının Türk kamu düzenine aykırı düşüp düşmeyeceği konusunda ayrıntılı bilgi için bkz Sayman (n 69) 31-32. Sayman; 1992 tarihli eserinde, Türk hukukunda, asgari evlenme yaşını tamamlamadan yapılan evliliklerin iç hukuktaki müeyyidesinin nisbi butlan olduğu, mutlak butlan sebebi olarak düzenlenmediği görüşünden yola çıkarak, TMK' dan daha küçük evlenme yaşını benimseyen yabancı hukuk hükümlerinin Türk kamu düzenine ters düşmeyeceği görüşündedir. Ancak, yukarıda da belirttiğimiz üzere, günümüzde, TMK'da öngörülen asgari evlenme yaşını tamamlamadan yapılan evlilikler, Türk doktrininde tartışmalı olmakla birlikte; Yargıtay içtihatları uyarınca "yok" hükmünde kabul edilmektedir. Bkz (n 108).

133 Kararlar için bkz BGH, Beschluss vom 14.11.2018 - XII ZB 292/16, para 44.

134 Türk Medeni Kanunu'nda öngörülen evlenme ehliyet ve şartlarının, soyut olarak mutlak kamu düzeni nitelikleri ile ele alınmasının doğru olmadığı yönünde bkz Sayman (n 69) 23-26.

135 "Çocuğun üstün menfaati ilkesi” ve bu ilkenin çocukla ilgili yabancıllk unsuru içeren uyuşmazlıklarda yetkili yabancı hukukun uygulanmasında kamu düzenine aykırılık değerlendirmesinde nasıl dikkate alınması gerektiği yönünde ayrıntı bilgi için bkz Rona Serozan, Cocuk Hukuku (2. Bası, Vedat Kitapçılık 2017) 65-67; Burak Huysal, Devletler Özel Hukukunda Velayet (Legal 2005) 153-158; Günseli Gelgel, Devletler Özel Hukukunda Çocuk Hukukundan Doğan Problemler (Beta 2012) 29-36; Faruk Kerem Giray, Milletlerarası Özel Hukukta Kaçırılan ve Alıkonan Çocukların İadesi (Beta 2010) 50. 
yaşına ilişkin olarak kamu düzeni değerlendirmesinde kesin bir asgari yaş sınırından bahsedilememesinin en önemli sebeplerinden birisi de, her bir somut olayda, çocuğun bireysel gelişiminin göz önünde bulundurulması ve esasen "çocuğun üstün menfaatinin" dikkate alınması gerekliliğinden kaynaklanmaktadır ${ }^{136}$.

Nitekim BM Çocuk Hakları Sözleşmesi'nde de, çocuk yaşta evliliklerin geçersizliğine ilişkin herhangi bir asgari yaş sınırı öngörülmemiştir. Sözleşme'nin 8. maddesi gereği, çocuğun özel hayatı ve aile hayatının korunması esastır. Ayrıca Sözleşme m 3/1 uyarınca; çocuklarla ilgili adli ve idari her türlü eylem ve işlemde “çocuğun üstün menfaati”nin öncelikle gözetileceği hüküm altına alınmıştır. Sözleşme m 12 uyarınca ise; her çocuğun kendisi ile ilgili kararlarda görüşünü serbestçe ifade etme hakkı olduğu ve çocuğun olgunluk durumuna ve yaşına göre mutlaka görüşüne başvurulması ve iradesine saygı gösterilmesi gerektiği ifade edilmiştir.

Ayrıca, AKPM'nin, 2005 tarihli Çocuk Evlilikler Hakkında Tavsiye Kararı'nda da, Konsey üyesi devletlere, yabancı ülkede gerçekleştirilen çocuk evliliklerin tanınmamasına ilişkin hukuki düzenlemeler yapmaları tavsiye edilirken; özellikle mağdur (çocuk) tarafından başka türlü ileri sürülemeyecek evlenmenin sonuçlarına ilişkin hakların güvence altına alınabilmesi amacıyla, tanımanın, "mağdurun (çocuğun) üstün yararına olduğu haller"de çocuk yaşta evliliklerin tanınmasını mümkün kılacak düzenlemelere de yer verilmesi gerektiği vurgulanmıştır ${ }^{137}$. Bu itibarla, 16 yaş altı evliliğe imkân veren yabancı hukuk hükmünün uygulanması sonucu çocuk yaşta evliliğin tanınmasının Türk kamu düzenini açıkça ihlal ettiğine karar verilebilmesi için; somut olayda, tanıma anında 16 yaşını doldurmamış olan çocuğun evlilik için yeterli olgunlukta olmadığına ilişkin veriler bulunmalı ve en önemlisi “çocuğun üstün menfaati” de evliliğin geçersiz olmasını gerektirmelidir.

Diğer taraftan, kanaatimizce, yabancı hukuka tabi 16 yaş altı evliliklerin tanınmasında Türk kamu düzenine aykırılık değerlendirmesinde, Türk toplumunun değerlerinin, kamu sağlığının ve çocuğun maddi-manevi varlığının korunması bağlamında, çocuk yaşta evliliklerin ceza hukuku boyutunun da göz önünde bulundurulması gerekir. Nitekim 14 yaşındaki Suriye vatandaşı kız çocuğu tarafından Suriye hukukuna göre yapılmış evliliğin Alman kamu düzenine aykırılık teşkil etmediğine ilişkin 2016 tarihli Bamberg Bölge Yüksek Mahkemesi ve 2018 tarihli Alman Federal Mahkemesi kararlarında da, Alman Ceza Kanunu'nun (Strafgesetzbuch- StGB) "çocuk istismarı"nı düzenleyen hükümlerine değinilmiştir. Kararlarda; StGB § 176/1 uyarınca, Alman hukukunda “çocuğun cinsel istismarı"nda yaş sınırının 14 yaş olduğu vurgulanmış ve 14 yaşını tamamlamış çocuklar bakımından cinsel istismar suçundan cezai sorumluluğun doğabilmesi için

\footnotetext{
136 BGH, Beschluss vom 14.11.2018 - XII ZB 292/16, para 44-45-46.

137 PACE 'Resolution on Forced Marriages and Child Marriages 2005' (n 12) para 14.2.4.

138 Strafgesetzbuch in der Fassung der Bekanntmachung vom 13. November 1998 (BGB1 I S 3322).
} 
somut olay bazında bir değerlendirme yapılması gerektiği belirtilmiştir. Buradan hareketle, 14 yaşını tamamlamış çocuklar tarafından yabancı ülkede yapılan evliliklerin, direkt olarak Alman kamu düzenine aykırı olduğuna ve evliliklerin geçersiz olduğuna hükmedilemeyeceği; somut olayın şartlarının değerlendirilmesi gerektiği ifade edilmiştir ${ }^{139}$.

Türk Ceza Kanunu m 103(a) uyarınca "çocuğun cinsel istismarı"nda yaş sınırı 15 yaş olarak belirlenmiş olduğuna göre ${ }^{140}$; kanaatimizce, yabancı ülkede yapılan çocuk yaşta evliliklerin tanınmasında, eşlerden birinin tanıma anında 15 yaşını tamamlamamış olması halinde, böyle bir evliliğin tanınmasının somut sonuçları Türk kamu düzenine açıkça aykırı sayılmalı ve evliliğin geçersiz olduğuna hükmedilmelidir. Bu noktada, kanaatimizce, eşlerden birinin tanıma anında 15 yaşını tamamlamamış olduğu yabancı hukuka göre yapılmış evlenmelerin tanınmasına ilişkin Türk kamu düzenine aykırılık değerlendirmesinde, tanıma (iptal davası) anında çocuğun gebe kalmış olup olmaması da dikkate alınmamalıdır. Zira Türk hukukunda, iptal davası açıldığı sırada, kadının gebe kalması hali, sadece 17 yaşını doldurmuş olup yasal temsilcinin izni olmaksızın yapılan evlilikler bakımından bir iptal engeli olarak düzenlenmiştir (TMK m 153/2). Türk Medeni Kanunu'nda, 17 yaşın altında olağanüstü evlenme koşullarını yerine getirmeksizin yapılan evlenmelerin iptalini engelleyici herhangi bir sebep ise düzenlenmemiştir. Bu nedenle, iptal davası sırasında, gebe kalmış olma, tek başına, yabancı hukuka tabi 17 yaşın altında yapılmış bir çocuk yaşta evliliğin Türk kamu düzenine aykırı olmadığı sonucunu doğurmaz ve bu evliliğin iptalini engelleyemez ${ }^{141}$. Ayrıca 15 yaşını tamamlamamış çocuklar bakımından, cinsel istismar suçu, TCK m 130(a) hükmü uyarınca şikayete tabi bir suç olmadığı gibi; çocuğun gebe kalması bir hukuka uygunluk sebebi de değildir.

Tanıma anında eşlerden her ikisinin de 15 yaşını doldurmuş (ancak 16 yaşını doldurmamış) olduğu yabancı hukuka tabi evlilikler bakımından ise, Türk kamu düzenine aykırılık değerlendirmesinde; Türk toplumunun değerleri, Türk aile yapısı, kamu sağlığı, bireyin maddi-manevi varlığını koruma ve geliştirme hakkı ve toplumsal cinsiyet eşitliğinin korunması ile "çocuğun üstün menfaatinin korunması" arasında bir denge sağlanmalıdır. Kamu düzenine aykırılık gerekçesiyle böyle bir evliliğin tanınmasının reddi, "çocuğun üstün menfaatinin" ihlaline ve bu anlamda somut olayda daha büyük mağduriyetlere sebebiyet vermemelidir. Bu itibarla, kanaatimizce, tanıma anında eşlerin 15 yaşını doldurmuş (ancak 16 yaşını doldurmamış) oldukları

\footnotetext{
139 OLG Bamberg, Beschluss vom 12.05.2016 - 2 UF 58/16, para 28; BGH, Beschluss vom 14.11.2018 - XII ZB 292/16, para 47.

140 TCK m 103: “(...) Cinsel istismar deyiminden; (a) On beş yaşın tamamlamamış veya tamamlamış olmakla birlikte fiilin hukuki anlam ve sonuçlarını algılama yeteneği gelişmemiş olan çocuklara karşı gerçekleştirilen her türlü cinsel davranış, (b) Diğer çocuklara karşı sadece cebir, tehdit, hile veya iradeyi etkileyen başka bir nedene dayalı olarak gerçekleştirilen cinsel davranışlar anlaşılır".

141 Bu itibarla; Gençcan'ın, butlan kararı verilmeden önce 17 yaşına ulaşılmışsa, bu evlenmelerin nisbi butlanla batıl sayılması ve butlan kararı verilmeden önce 18 yaşına ulaşılıp ergin olunmuşsa veya kadın gebe kalmışsa, evlenmenin iptaline karar verilmemesi gerektiği yönündeki görüşüne katılmamaktayız (Görüş için bkz Gençcan (n 108) 94).
} 
yabancı hukuka göre yapılmış evlenmelerin tanınmasına ilişkin kamu düzenine aykırılık değerlendirmesinde, tanıma (iptal davası) anında çocuğun gebe kalmış veya doğum yapmış olması, "çocuğun üstün mefaatinin korunması" amacıyla sınırlı olmak üzere dikkate alınabilmelidir.

\section{c. Türk Kamu Düzenine Aykırılık Sonucu Evlenmenin Geçersizliğinin Müeyyidesine Uygulanacak Hukuk}

Evlenme yaşına uygulananacak yabancı hukukun ilgili hükümlerinin uygulanmasının somut sonuçları itibariyle çocuk yaşta bir evliliğin tanınmasının MÖHUK m 5 uyarınca Türk kamu düzenine açıkça aykırılık teşkil ettiğine karar verilmesi ve Türk hukukunda bu evlenmeye geçerlilik tanınmaması halinde, evlenmenin geçersizliğinin müeyyidesinin hangi hukuka göre belirleneceğine de karar vermek gerekmektedir.

Türk milletlerarası özel hukuk doktrininde, görüş birliği ile kabul edildiği üzere, evlenme ehliyet ve şartlarına aykırılığın müeyyidesini ihlal edilen ülke hukuku tayin edecektir. Buna göre; evlenme yaşına hangi hukuk uygulandı ise, asgari evlenme yaşına uymamanın, yokluk, mutlak butlan veya nisbi butlanla $m$ ı hükümsüz sayılacağına ve bu müeyyidenin sonuçlarına da aynı hukukun uygulanması esastır ${ }^{142}$. O halde yetkili yabancı hukukun evlenme yaşına ilişkin hükümlerinin somut olayda Türk kamu düzenine açıkça aykırı sonuçlar yarattığı gerekçesiyle uygulanmaması neticesinde olaya hangi hukuk uygulanarak evlenmenin geçersiz olduğuna karar verilecek ise, geçersizliğin türü ve sonuçlarına da aynı hukuk uygulanmalıdır.

Bu noktada tartışma, yetkili yabancı hukukun ilgili hükümlerinin Türk kamu düzenine aykırı olduğuna karar verildiği hallerde, yabancı hukuk yerine doğrudan Türk hukukunun mu (lex fori) uygulanacağı yoksa öncelikle yetkili yabancı hukuka (lex causae) başvurularak o hukuk içinde bir çözüm mü aranması gerektiğine ilişkindir. Dolayısıyla tartışmanın kaynağı, kamu düzenine aykırılık müdahalesinin olumsuz etkisine bağlanan sonuçlara ilişkin görüş ayrılıklarıdır ${ }^{143}$.

Birinci görüşe göre ${ }^{144}$; yetkili yabanc1 hukuk kuralının kamu düzenine aykırılık sebebiyle uygulanmaması halinde kamu düzeni ihlal edilen hukuk (lex fori) uygulanmalıdır. Zira yabancı hukukun kamu düzenine aykırllı sebebiyle uygulanmamasına karar verilmesi ile aslında dava, kamu düzeni ihlal edilen hukuka göre bir hukuki çözüme kavuşarak sona ermiştir. Misalen; Suriye hukukunda 13 yaşını tamamlayan kız çocuklarının evlenmesine imkân veren kuralın somut

\footnotetext{
142 Ayrıntılı bilgi için bkz Sayman (n 69) 193 vd; Uluocak (n 69) 64; Tekinalp ve Uyanık (n 69) 149; Nomer (n 69) 239; Şanlı, Esen ve Ataman-Figanmeşe (n 69) 133; Çelikel ve Erdem (n 69) 233; Doğan, Milletlerarası Özel Hukuk (n 69) 330-331.

143 Görüşler hakkında ayrıntılı bilgi için bkz Sayman (n 69) 194-195; Nomer (n 69) 180-181; Doğan, Milletlerarası Özel Hukuk (n 69) 253-254.

144 Sayman (n 69) 194-195; Şanll, Esen ve Ataman-Figanmeşe (n 69) 92.
} 
olaydaki neticeleri Türk kamu düzenine aykırı görülerek uygulanmadığında; aslında, Türk hukukunun öngördügü̈, evlenmenin geçersiz olduğu yönündeki hukuki çözüm kendiliğinden doğmaktadır. Hukuki çözüme ulaşıldığının kabulü için, kamu düzeni ihlal edilen Türk hukukunda yer alan kanun maddelerinden birinin açık olarak uygulanması gerekmemektedir.

Dolayısıyla birinci görüş benimsendiğinde; MÖHUK m 5 kapsamında yabancı hukukun olaya uygulanan hükmünün somut sonucu olarak evliliğin tanınmasının Türk kamu düzenine açıkça aykırılık teşkil ettiğine karar verilmesi ve Türk hukukunda bu evlenmeye geçerlilik tanınmaması halinde, evlenmenin geçersizliğinin müeyyidesi Türk hukukuna (lex fori) göre belirlenmelidir. Bu sonuç, evlenmenin geçerlilik şartıyla, bu şarta uymamanın müeyyidesinin aynı hukuk hükümlerine tabi olması kuralını da zedelememektedir. Zira bu görüşe göre, yabancı hukukun uygulanması, kamu düzenine aykırı olmamasına bağlı olduğundan, evlenmenin geçerlilik şartına da aslında Türk hukuku uygulanmış olmaktadır ${ }^{145}$. Buna göre; tanıma anında eşlerden birinin 16 yaşını doldurmamış olduğu Suriye hukukuna göre yapılmış bir evliliğin tanınmasının Türk kamu düzenini açıkça ihlal ettiğine karar verilmesi halinde, Türk hukukundaki müeyyide uygulanacak ve bu evlilikler Yargıtay içtihatlarına göre, "yok hükmünde" kabul edilecektir.

İkinci görüşe göre ise ${ }^{146}$; yetkili yabancı hukuk kuralının kamu düzenine aykırılık sebebiyle uygulanmaması halinde, ortaya bir boşluk çıkmaktadır. Zira henüz daha herhangi bir hukukta yer alan maddi hukuk kurallarına göre olay çözüme ulaşmış değildir. Sadece kamu düzeni ihlal edilen hukukun temel hukuk prensipleri çerçevesinde bir değerlendirme yapılmış ve yabancı hukukun ilgili hükmünün uygulanması neticesinde ortaya çıkan sonuçlar o devletin kamu düzenine aykırı görülmüştür. $\mathrm{Bu}$ sebeple, yabancı hukukun ilgili kurallarının uygulanması engellenmiştir. Esas olan yetkili yabancı hukukun uyuşmazlığa uygulanması olduğundan; bu boşluk öncelikle yetkili yabancı hukukun (lex causae) hükümleriyle doldurulmaya çalışılmalıdır. Yabancı hukukta kamu düzenini ihlal eden hükmü telafi edebilecek, "intibak" edilebilecek başka bir hüküm var ise o hüküm uygulanarak hukuki çözüme ulaşılmalıdır. Ancak yetkili yabancı hukukta olaya ilişkin tüm hükümler bütünü ile kamu düzenini ihlal ediyorsa, bu durumda kamu düzeni ihlal edilen hukukun (lex forinin) uygulanması söz konusu olabilecektir.

2018 tarihli Alman Federal Mahkemesi kararında da, kamu düzeni müdahalesinde bu görüş benimsenerek, Alman kamu düzenine aykırılık olup olmadığına karar verilirken; Suriye hukukunun 13 yaşında kız çocuklarının evlenmesine imkân veren hükmünün uygulanmaması neticesinde ortaya çıan boşluğu doldurmak üzere, önce Suriye hukukuna gidilmiş; Suriye hukukunda asgari evlenme yaşına aykırılık halinde

\footnotetext{
145 Sayman (n 69) 193-194.
}

146 Nomer (n 69) 181-182. 
evlenmenin müeyyidesine bakılmış ve iptal edilebilirlik müeyyidesinin Alman hukukunda (eski BGB § 1314) öngörülen müeyyide ile paralel olduğu gerekçesiyle Suriye hukukunun ilgili hükmünün uygulanmasının somut sonuçlarının Alman kamu düzenini ihlal etmediğine karar verilmiştir ${ }^{147}$.

Dolayısıyla, ikinci görüş benimsendiğinde; MÖHUK m 5 uyarınca, yetkili yabancı hukukta yer alan evlenme yaşına ilişkin hükümlerin olaya uygulanmasının somut sonucu olarak evliliğin tanınmasının Türk kamu düzenine açıkça aykırılık teşkil ettiğine karar verilmesi halinde, evlenmenin geçersizliğinin müeyyidesi, öncelikle yetkili yabancı hukuka (lex causae) göre belirlenecektir. Bu durumda da, evlenmenin geçerlilik şartıyla, bu şarta uymamanın müeyyidesinin aynı hukuk hükümlerine tabi olması kuralı zedelenmemektedir. Zira bu görüşe göre, yabancı hukuk kuralının kamu düzenine aykırılık sebebiyle uygulanmaması neticesinde, henüz hâkim herhangi bir maddi hukuk kuralını uygulayarak hukuki çözüme ulaşmış değildir. Yetkili yabancı hukukta (lex causae), asgari evlenme yaşına uyulmaması halinde evlenmenin geçersizliğini öngören, boşluğu doldurabilecek bir yabancı hukuk kuralının bulunması halinde; geçerlilik şartıyla bu şarta uymamanın müeyyidesine aynı hukuk (lex causae) uygulanmış olmaktadır ${ }^{148}$.

İkinci görüşe göre; tanıma anında eşlerden birinin 16 yaşını doldurmamış olduğu Suriye hukukuna göre yapılmış bir evliliğin tanınmasının Türk kamu düzenini açıkça ihlal ettiğine karar verilmesi halinde, öncelikle Suriye hukukuna bakılacaktır. Suriye hukukunda, asgari evlenme yaşına (kız çocukları için 13 yaş, erkek çocukları için 15 yaş) uyulmaması halinde evlenmenin "iptal edilebilir" olduğu ve evlenme iptal edilinceye kadar geçerli bir evliliğin tüm sonuçlarını doğurduğu kabul edilmektedir (SDDK m 47-51) $)^{149}$. Türk hukukunda ise, böyle evlilikler, Yargıtay'nn yerleşik içtihatları ile "yok" hükmünde kabul edilmekte ve yokluğun sonuçları evlenme anından itibaren etkisini göstermektedir. Bu nedenle, bu noktada, Türk hâkimince, Suriye hukukunda asgari evlenme yaşına uyulmaksızın yapılan evlenmeler için öngörülen "iptal edilebilirlik" müeyyidesinin de, Türk kamu düzenine açıkça aykırı olup olmadığ değerlendirilmelidir.

Bu hususta kanaatimizce, yine "çocuğun üstün menfaatinin" gözetilmesinin gereği olarak, tercih, mağdur olan çocuğun geçersiz evlilik sebebiyle elde ettiği hakları ileri sürebilmesini sağlamaya yönelik olmalıdır. Bunu sağlayacak olan da, evlenmenin geçersiz olduğu yönündeki karar verilinceye kadar evlenmenin geçerli bir evliliğin sonuçlarını doğurmasına imkân veren Suriye hukukundaki "iptal edilebilirlik" müeyyidesidir. Bu bakımdan, "çocuğun üstün menfaatinin korunması" ilkesi gereği,

47 BGH, Beschluss vom 14.11.2018 - XII ZB 292/16, para 16-17, para 38.

148 Sayman (n 69) 197.

149 Bkz OLG Bamberg, Beschluss vom 12.05.2016 - 2 UF 58/16, para 25; BGH, Beschluss vom 14.11.2018 - XII ZB 292/16, para 15 . 
Suriye hukukundaki "iptal edilebilirlik" müeyyidesinin Türk kamu düzenine açık bir aykırılık oluşturmadığı kabul edilmeli ve evlenmenin geçersizliğinin müeyyidesine ve sonuçlarına Suriye hukuku uygulanmalıdır. Bu sonuç, AKPM'nin, 2015 tarihli Tavsiye Kararında dikkat çektiği; mağdur çocuk tarafından başka türlü ileri sürülemeyecek evlenmenin sonuçlarına ilişkin hakların güvence altına alınabilmesi amacıyla, evliliğin tanınmasının "çocuğun üstün menfaati”ne olduğu hallerde, yabancı hukuka tabi çocuk yaşta evliliklere geçerlilik tanınması tavsiyesi ile de bağdaşmaktadır ${ }^{150}$.

Görüldüğü üzere; kamu düzenine aykırılık müdahalesinin olumsuz etkisine bağlanan sonuçlara ilişkin olarak; yetkili yabancı hukukun kamu düzenine aykırılık sebebiyle uygulanmaması halinde, lex forinin uygulanması yönündeki birinci görüş benimsendiğinde; tanınması kamu düzenine açıkça aykırı bulunan çocuk yaşta evlenmeler, Türk hukukunun uygulanması sonucu "yok" hükmünde kabul edilecektir. Yetkili yabancı hukuk kuralının kamu düzenine aykırılık sebebiyle uygulanmaması halinde, öncelikle yabancı hukuka başvurulması yönündeki ikinci görüş benimsendiğinde ise, tanınması kamu düzenine açıkça aykırı bulunan çocuk yaşta evlenmeler bakımından, yabancı hukukta öngörülen müeyyide ile Türk hukukunda öngörülen müeyyide arasında, "çocuğun üstün menfaati” göz önünde bulundurularak bir tercih yapılması imkânı doğmaktadır ${ }^{151}$.

Nitekim MÖHUK m 5 hükmünün, yetkili yabancı hukukun olaya uygulanan hükmünün somut sonuçlarının Türk kamu düzenine açıkça aykırı olması ve söz konusu yabancı hukuk kuralının uygulanmadığı durumda, Türk hukukunun, gerekli görülen hallerde uygulanacağına ilişkin düzenlemesi, ikinci görüşün benimsendiğini ifade etmeye yöneliktir. Hükümde, gerekli görülen hallerden kasıt, Türk kamu düzeni müdahalesi ile yetkili yabancı hukuk kuralının uygulanmasının engellenmesi sonucu ortaya çıan boşluğu doldurmak üzere, yetkili yabancı hukukta Türk kamu düzenini ihlal etmeyecek herhangi bir hukuki çözümün bulunamadığı hallerdir ${ }^{152}$. Kamu düzeni

\footnotetext{
150 PACE 'Resolution on Forced Marriages and Child Marriages 2005' (n 12) para 14.

151 Sayman; evlenmenin geçerliliğine uygulanacak hukukta, eşlerden her birinin evlenme anındaki milli hukuku olarak aynı anda iki farklı hukukun uygulanmasının gerektiği hallerde, her iki hukukta da evlenmenin geçersizliği için aynı hukuki müeyyide öngörülmüşse, bu durumda, evlenmenin tarafı olan eşlerin kendi aralarında ve üçüncü kişilerle giriştikleri ilişkilerden doğan menfaatlerin korunması için, evlenmeyi baştan itibaren hükümsüz kılan hukukun değil, geçersizliğine iliş̧in kararın verildiği andan itibaren hükümsüz kılan hukukun tercih edilmesi gerektiği görüşündedir. Bkz Sayman (n 69) 269. Kanaatimizce, Sayman'ın, evlenmenin ehliyet ve şartlarına iki ayrı hukukun uygulanması ve iki hukukta da aynı ağırlıktaki müeyyidenin farklı sonuçlara sebebiyet vermesi halinde, somut olay adaletini ve evlenmenin doğasını gözeterek yaptığı bu tercih, kamu düzenine aykırılık müdahalesinin sonuçlarında da gözetilmelidir.

152 Aynı yönde bkz Nomer (n 69) 182; Akıncı ve Gökyayla (n 69) 8. Şanlı/Esen/Ataman-Figanmeşe; MÖHUK m 5 hükmünün lafzının bu yönde olduğunu belirtmekle birlikte; yabancı hukukun Türk kamu düzenini açıkça ihlal ettiği durumlarda, uygulanması engellenen yabancı hukuk yerine "gerekli olduğunda" Türk hukukunun uygulanacağının söylenmesinin, esasen gerçekçi olmadığı, pratikte yabancı hukukun engellendiği her durumda, yabancı hukuka tekabül eden Türk maddi hukuk kaideleri uygulanarak davanın karara bağlandığını ifade etmektedir. Bkz Şanlı, Esen ve Ataman-Figanmeşe (n 69) 91. Doğan da; günümüzde karşılaștırmalı hukukta, kamu düzeninin menfi etkisinin ve menfi etki sonucu bir boşluğun ortaya çıkması halinde müspet etkisinin kabul edildiğini; yetkili yabancı hukukun olaya uygulanması sonucu kamu düzenine aykırılık gereği o hükümlerin uygulanmasından vazgeçilmesi halinde bir boşluk ortaya çıkar ise hâkimin kendi hukukunu uygulayarak boşluğu doldurmasının kabul edildiğini ifade etmektedir. Bkz Doğan, Milletlerarası Özel Hukuk (n 69) 255.
} 
müdahalesi sonucu Türk hukukunun uygulanmasının gerekli görülmeyeceği haller ise, işte çalışmamızda ele aldığımız, asgari evlenme yaşına uyulmamasına ilişkin olarak yetkili yabancı hukukta bir hukuk çözüm veya müeyyidenin benimsenmiş olduğu ve bu müeyyidenin de Türk kamu düzenine aykırılık teşkil etmediği durumlardır.

Netice itibariyle, kanaatimizce, MÖHUK m 5 hükmü gereğince, geçici koruma altındaki Suriyelilerin Türkiye'ye gelmeden önce Suriye hukukuna göre yapmış oldukları çocuk yaşta evliliklerin Türkiye'de tanınmasında; tanıma (iptal davası) anında eşlerden biri 16 yaşını doldurmamışsa ve Türk hâkimince, bu evliliğin tanınmasının Türk kamu düzenini açıça ihlal ettiği değerlendirilmişse, bu evlenmenin geçersizliğinin türü ve sonuçlarına yetkili yabancı hukuk olan Suriye hukuku uygulanmalı ve evlenmenin "iptal edilebilir" olduğu değerlendirilmedir. "İptal edilebilirliğin" türü olarak ise; Suriye hukukunda, eşlerin veya onların yasal temsilcilerinin iptal talebi olmaksızın, bir kamu makamı olarak Şeriat mahkemelerinin re'sen evliliğin tescilini reddetmek suretiyle evlenmenin hükümsüzlüğüne karar verebilmesi itibariyle, kanaatimizce, "iptal edilebilirliğin" türü "mutlak butlan" olarak nitelendirilmeli ${ }^{153}$ ve iptal davası açma şartları Türk Medeni Kanunu'ndaki evlenmenin "mutlak butlanı"na ilişkin hükümlere tabi olmalıdır.

Uygulamada; yabancılar tarafından yabancı hukuka göre yapılmış bir çocuk yaşta evliliğin geçerliliğinin mahkeme önüne gelebilmesi; evliliği yapmış olanların kendileri, yasal temsilcileri veya ilgili kişilerce iptal davası açılmadıkça, ancak resmi makamlarca durumun tespiti halinde mümkün olacaktır. Uluslararası koruma başvurucuları veya geçici korumaya tabi Suriyeliler bakımından ilk olasılık, koruma bulmak amacıyla Türkiye'ye girdikleri ve resmi makamlara başvurdukları anda çocuk yaşta evlilik vakasının tespit edilmesidir. Ancak, özellikle geçici koruma altındaki Suriyeliler kitlesel şekilde giriş yaptıkları ve şahsi bilgileri bakımından beyan esasına göre kayıt yapıldığı için, Türkiye'ye giriş yaptıkları sırada çocuk yaşta evlilik vakaları tespit edilememiş olabilir. Bu durumda, ikinci ve uygulamada en sık rastlanan olasılık, gebelik veya doğum sırasında bir sağlık merkezine başvurulması ile çocuk yaşta evlilik vakasının tespit edilmesidir. Her iki olasılıkta da, durumu tespit eden makamlarca, Cumhuriyet Başsavcılığına bildirim yapılacaktır. Bildirim üzerine, kanaatimizce, yabancı hukuka tabi çocuk yaşta evliliğin müeyyidesi "mutlak butlan" olduğundan, Cumhuriyet savcılıklarınca evlenmenin iptali davası açılmalıdır.

İptal davasında, yabancı hukuka tabi bir evlenmenin Türk hukukuna göre geçerli olup olmadığının tespitinde, kanaatimizce, tarafların "iptal davası (tanıma) anındaki" yaş durumlarına göre bir değerlendirme yapılması gerekmektedir. Dava sırasında, eşlerden her ikisi de 16 yaşını doldurmuş ise ve somut olayda zorla evlendirme bulgusu yoksa, kanaatimizce, kamu düzenine aykırılık sebebiyle evlenmenin

Bkz yukarıda (n 113) 
butlanına hükmedilmemelidir. Zira Türk hukukunda, hakim kararıla istisnai bir şekilde de olsa 16 yaşını doldurmuş olanların evlenmesine imkan tanınmış olması karşısında, yabancı hukuka göre yapılmış bu yaştaki evliliklerin Türk kamu düzenini tahammül edilemeyecek derecede açık bir şekilde ihlal ettiğini ileri sürmek mümkün gözükmemektedir. Eşlerden biri, 16 yaşını doldurmamış ise, bu durumda, kamu düzenine aykırılık değerlendirmesi, yukarıda açıkladığımız esaslar çerçevesinde "çocuğun üstün menfaati" gözönünde bulundurularak yapılmalıdır. Bununla birlikte, eşlerden biri, henüz 15 yaşını doldurmamış ise, kanaatimizce, böyle bir evliliğin tanınmasının Türk kamu düzenini ihlal edip etmediği, TCK m 103(a) uyarınca "çocuğun cinsel istismarı" suçu gözönünde bulundurularak yapılmalı ve "çocuğun cinsel istismarı" suçunu teşkil eden bu evlenmenin mutlak butlanına hükmedilmelidir ${ }^{154}$.

\section{Türk Kamu Düzenine Aykırılık Gerekçesiyle Çocuk Yaşta Evliliklerin Tanınmamasının Aile Hayatına Saygı Hakkı Kapsamında Değerlendirilmesi}

Geçici koruma altındaki Suriyelilerin, Türkiye'ye gelmeden önce yaptıkları çocuk yaşta evliliklerin tanınmasının Türk kamu düzenine aykırılık gerekçesiyle reddinin, Avrupa İnsan Hakları Sözleşmesi ${ }^{155}$ (AİHS) çerçevesinde, "aile hayatına saygı hakkının korunması" yükümlülüğününe bir ihlal teşkil edip etmediğinin de değerlendirilmesi gerekmektedir.

"Aile hayatına saygı hakkının korunması”, Avrupa İnsan Hakları Sözleşmesi'nin 8. ve 12. maddeleri ${ }^{156}$ çerçevesinde sağlanmakta ve esasen AİHS $m 8$ bu hakkın korunması bakımından temeli oluşturmaktadır. AİHS m 8 kapsamında "aile hayatına sayg1 hakkı"nın değerlendirilmesinde, ilk olarak, "aile" kavramının tanımının yapılması gerekmektedir. Zira aile hayatının korunması için öncelikle bir "aile hayatı”nın varlı̆ğ gerekmektedir. Avrupa İnsan Hakları Mahkemesi’nin (AİHM), "aile hayatına saygı hakkının korunması" ile ilgili yerleşik içtihatlarına bakıldığında; "aile hayatı"nın var olup olmadığının, "fiiliyatta yakın kişisel bağların bulunmasına bağl olgusal bir mesele" olarak nitelendirildiği görülmektedir ${ }^{157}$. Bu sebeple; AİHS m 8 anlamında "aile hayatı", gerçek ve hukuka uygun olarak kurulmuş bir evlilikteki evli çiftlerin yanı sıra, evlilik dışı yaşam birlikteliklerini de kapsamına almaktadır ${ }^{158}$.

\footnotetext{
154 Bkz yukarıda III(B)(2)(b).

155 European Convention on Human Rights, 04.11.1950. RG. 19.03.1954-8662.

156 AIHS m 8/1 uyarınca; “(1) Herkes özel ve aile hayatına, konutuna ve yazışmasına saygı gösterilmesi hakkina sahiptir”. AİHS m 12 uyarınca ise; "evlenme çağına gelen her erkek ve kadın, bu hakkın kullanımını düzenleyen ulusal yasalara uygun olarak evlenme ve aile kurma hakkina sahiptir".

157 K and T v Finland [GC] App No 25702/94 (ECHR, 12 July 2001) para 150. Ayrıca bkz Gülay Arslan Öncü, Avrupa İnsan Hakları Sözleşmesinde Özel Yaşamın Korunması Hakkı (Beta 2011) 264; Wijffelman (n 44) 114.

158 Keegan v Ireland App No 16969/90 (ECHR, 26 May 1994) para 44; Al-Nashif v Bulgaria App No 50963/99 (ECHR, 20 June 2002) para 112.
} 
Evlilik dışı yaşam birlikteliklerinin "aile hayatı" kapsamında değerlendirilebilmesi için bazı ölçütler aranmaktadır. Bu ölçütler; birlikte yaşama, birlikteliğin süresi ve çiftin birbirlerine karşılıklı olarak, çocuk sahibi olmak veya başka bir yolla bağlılıklarını göstermeleri olarak sıralanmaktadır. Bu itibarla, hukuken geçersiz bir evlilikteki çiftler arasındaki ilişkinin, yukarıda sayılan ölçütlere sahip bulunması halinde, AİHS m 8 kapsamında bir "aile hayatı"nın varlığı söz konusu olacaktır ${ }^{159}$.

Bununla birlikte; AİHS m 8 uyarınca "aile hayatına saygı hakkı", mutlak nitelikte olmayıp, sınırlanabilir niteliktedir. Aile hayatına sayg1 hakkına getirilebilecek sınırlama koşulları ise AİHS m 8/2'de düzenlenmiştir ${ }^{160}$. Buna göre; "aile hayatına saygı hakkı"na bir kamu makamı tarafından müdahalenin ihlal teşkil etmemesi için; müdahalenin, (1) yasayla öngörülmüş olması, (2) meşru bir amaca yönelik olması ve (3) demokratik bir toplumda gerekli olması, daha açık bir ifadeyle, müdahalenin izlenen meşru amaç ile "ölçülü" olması gerekmektedir ${ }^{161}$. AİHS m 8/2'de, yasayla öngörülecek ölçülü müdahalenin yönelebileceği meşru amaçlar ise; ulusal güvenlik, kamu güvenliği, ülkenin ekonomik refahı, düzenin korunması, suç işlenmesinin önlenmesi, sağlığın korunması, ahlakın korunması ve başkalarının hak ve özgürlüklerinin korunması olarak sayılmıştır.

AİHM kararlarında ifade edildiği üzere, AİHS m 8'in ana amac1, bireyin, kamu makamlarının keyfi ve ölçüsüz müdahalelerine karşı korunmasıdır. Ancak bu negatif yükümlülük yanında, kamu makamlarının aile hayatına etkin saygı kapsamında pozitif yükümlülükleri de mevcuttur. Söz konusu pozitif yükümlülük, kamu makamlarının, bireyin "aile hayatına saygı hakkı"nı güvence altına alacak gerekli önlemleri alıp almadığına ilişkindir ${ }^{162}$. Her iki yükümlülük kapsamında da, bireyin menfaatleri ile kamu menfaatleri arasındaki adil dengenin sağlanması gerekmektedir ${ }^{163}$. Bunun yanında, her iki yükümlülük kapsamında da, taraf devletlerin müdahalenin gerekliliği noktasında belirli bir takdir marjının bulunduğu kabul edilmektedir ${ }^{164}$. Devletlerin ekonomik, mali ve sosyal politikalarının uygulanması sonucu olan müdahalelerin gerekliliği noktasında ise, demokratik bir toplumda bu konularla ilgili olarak derin görüş ayrılıkları bulunabileceğinden, taraf devletlerin daha geniş bir takdir marjına

\footnotetext{
59 Arslan Öncü (n 157) 265; Wijffelman (n 44) 114. Ayrıca bkz X, Y and Z v the United Kingdom App No 21830/93 (ECHR, 22 April 1997) para 36; Kroon and Others v the Netherlands App No 18535/91 (ECHR 27 October 1994) para 30.

160 AİHS m 8/2: “(2) Bu hakkın kullanılmasına bir kamu makamının müdahalesi, ancak müdahalenin yasayla öngörülmüş ve demokratik bir toplumda ulusal güvenlik, kamu güvenliği, ülkenin ekonomik refahl, düzenin korunmasl, suç işlenmesinin önlenmesi, sağlığın veya ahlakın veya başkalarının hak ve özgürlüklerinin korunması için gerekli bir tedbir olması durumunda söz konusu olabilir".

161 Arslan Öncü (n 157) 356-357.

162 Wijffelman (n 44) 115. Ayrıca bkz Abdulaziz, Cabales and Balkandali v The United Kingdom App No 9214/80, 9473/81, 9474/81 (ECHR, 28 May 1985) para 67.

163 Arslan Öncü (n 157) 375-378; Wijffelman (n 44) 116. Ayrıca bkz Rodrigues Da Silva v The Netherlands App No 50435/99 (ECHR, 31 January 2005) para 39.

164 Arslan Öncü (n 157) 378-384. Ayrica bkz Hokkanen v Finland App No 19823/92 (ECHR, 23 September 1994) para 55.
} 
sahip oldukları kabul edilmektedir ${ }^{165}$. Evlenmenin şartlarına ilişkin olarak getirilen düzenlemeler de, Devletlerin sosyal politikaları kapsamında olduğundan, bu düzenlemeler ile "aile hayatına saygı hakkı"na müdahalenin gerekliliği konusunda, devletlerin daha geniş bir takdir marjına sahip oldukları değerlendirilmektedir ${ }^{166}$.

$\mathrm{Bu}$ çerçevede; yabancı bir ülkede yabanc1 hukuka göre geçerli bir şekilde gerçekleştirilmiş çocuk yaşta evliliğin, MÖHUK m 5 uyarınca Türk kamu düzenine açıkça aykırı görülerek tanınmamasının, "aile hayatına saygı hakkı"na bir ihlal teşkil edip etmediği iki aşamada değerlendirilmelidir. İlk aşamada; Türkiye dışında yabancı bir hukuka tabi olarak yapılan çocuk yaşta evliliklerin tanınmamasının AİHS m 8 ve m 12 kapsamında bir ihlal teşkil edip etmediğinin belirlenmesi; ikinci aşamada ise, çocuk yaşta evliliklerin tanınmaması üzerine alınacak tedbirlerin AİHS m 8 kapsamında ihlal teşkil edip etmeyeceğinin incelenmesi gerekmektedir.

Türkiye dışında yabancı bir hukuka tabi olarak yapılan çocuk yaşta evliliklerin kamu düzenine aykırllımülahazaslyla tanınmamasının, AIHSm 8 ve 12 kapsamında bir ihlal teşkil edip etmediği konusunda; AïHM'in Şerife Yiğit v Turkey kararındaki değerlendirmelerinin oldukça yol gösterici olduğu kanaatindeyiz. Kararda, AİHM, Türkiye' de gerçekleştirilen evlilikler bakımından dini nikâhı hukuken geçersiz kabul eden Türk Medeni Kanunu'nda yer alan yasal düzenlemeler sebebiyle, dini nikâh ile resmi nikâhın sonuçları bakımından farklı muameleye tabi olmasının, AİHS m 14 uyarınca ayrımcılık yasağını ve AİHS m 8 uyarınca aile hayatına saygı hakkını ihlal edip etmediğini incelemiştir. Mahkeme, söz konusu yasal düzenlemelerin yasal ve meşru amaca yönelik ölçülü bir müdahale teşkil edip etmediği hususundaki değerlendirmesinde; öncelikle, evliliğin maddi ve şekli geçerlilik şartlarına ilişkin düzenlemelerin, devletlerin sosyal politikaları kapsamında olması itibariyle, taraf devletlerin, düzenlemelerin gerekliliği hususunda geniş bir takdir hakkına sahip olduklarını hatırlatmıştır. Devamında Mahkeme; çok eşliliğin yasaklanması ve asgari evlenme yaşının ihdas edilmesi gibi Türk Medeni Kanunu'nda yer alan evlenmenin geçerlilik şartlarına ilişkin düzenlemelerin, toplumsal cinsiyet eşitliğine yönelik, kadınları koruyan hükümler olmaları sebebiyle, kamu düzeni ve başkalarının hak ve özgürlüklerinin korunması meşru amaçlarına yönelik, ölçülü düzenlemeler olduğu ve bu bakımdan AİHS m 8 ve 14 kapsamında bir ihlale yol açmadığı sonucuna varmıştı1 ${ }^{167}$.

AİHM, ZH and RH v Ísviçre kararında da ${ }^{168}$; evlenme anında 14 yaşında olan Afgan uyruklu bir kız çocuğunun evliliğinin tanınması talebinin, İsviçre kamu

\footnotetext{
165 Takdir marjının göreliliği konusunda bkz Arslan Öncü (n 157) 382; Şerife Yiğit v Turkey [GC] App No 3976/05 (ECHR, 2 November 2010) para 99.

166 Şerife Yiğit v Turkey [GC] App No 3976/05 (ECHR, 2 November 2010) para 99.

167 Şerife Yiğit v Turkey [GC] App No 3976/05 (ECHR, 2 November 2010) para 81-81, para 99. Şerife Yiğit kararı ve medeni olmayan evliliklere ilişkin diğer AİHM kararları hakkında ayrıca bkz Ekşi, Medeni Olmayan Evlilikler (n 112) 96-100.

168 ZH and RH v Switzerland App No 60119/12 (ECHR, 8 December 2015).
} 
düzenine açıkça aykırı olduğu gerekçesiyle, İsviçre Federal İdare Mahkemesi (Bundesverwaltungsgericht/Swiss Federal Administrative Court) tarafindan reddedilmesinin, AİHS m 8 kapsamında ihlal teşkil ettiği iddiasına yönelik başvuruyu incelemiş ve kararında; AİHS m 8 ve AİHS m 12'nin, taraf devletlere 14 yaşındaki bir çocuğun evliliğini tanıma yükümlülüğü getirdiği yönünde yorumlanamayacağını; AİHS m 12'nin açıkça taraf devletlerin milli hukuklarında asgari evlenme yaşına ilişkin düzenleme yapma imkânı sunduğunu ve çocuğun korunması ve güvenli aile ortamının teşvik edilmesi kapsamında, toplumun ihtiyaçlarını en iyi şekilde değerlendirecek ve bu ihtiyaçlara en iyi şekilde cevap verebilecek taraf devlet makamları yerine karar alma konusunda Mahkemenin çekimser kalması gerektiğini ifade ederek bir ihlal olmadığına hükmetmiştir ${ }^{169}$.

AİHM'in bu kararları 1şığında; kanaatimizce, Türkiye dışında yabancı hukuka tabi çocuk yaşta evliliklerin, Türk kamu düzenine açıkça aykırı olduğu gerekçesiyle Türkiye'de tanınmaması, AİHS m 8 ve m 12 uyarınca "aile hayatının korunması hakkı" kapsamında bir ihlal teşkil etmeyecektir.

Diğer taraftan; Türkiye dışında yabancı hukuka tabi olarak yapılan çocuk yaşta bir evliliğin kamu düzenine aykırılık gerekçesiyle tanınmaması, her ne kadar AİHS m 8 ve $\mathrm{m} 12$ kapsamında bir ihlal teşkil etmese de; böyle bir evliliğin geçersiz olması, fiili birliktelik içerisinde bulunan çiftin bir "aile hayatı" olup olmadığı sorusunu ortadan kaldırmamaktadır ${ }^{170}$. Zira "aile hayatı"nın varlı̆ğ hukuken geçerli yasal bir evliliği şart koşmamakta; evlilik dışı yaşam birliktelikleri de, AİHM kriterlerini sağladığı ölçüde "aile hayatı" olarak değerlendirilebilmekte ve AİHM m 8 kapsamında "aile hayatına saygı hakkı" korumasından yararlanabilmektedir. Bu nedenle; Türk kamu düzenine açıkça aykırı olduğu gerekçesiyle tanınmayan ve geçersiz kabul edilen, geçici koruma altındaki Suriyelilerin Türkiye'ye gelmeden önce Suriye hukukuna göre yaptıkları çocuk yaşta evlilik çerçevesindeki birliktelikler de, AİHM kriterleri dâhilinde "aile hayatı" say1labilecektir.

$\mathrm{Bu}$ bağlamda; yabancı hukuka tabi çocuk yaşta evliliklerin tanınmaması üzerine alınacak tedbirler de, AIHS $m 8$ kapsamında aile hayatına saygı hakkının korunması denetimine tabi olacaktır. Zira evliliğin geçersiz sayılması üzerine, Türk mahkemelerince, özellikle mağdur çocuk hakkında verilecek koruma kararları, "aile hayatına saygı hakkı"na müdahale teşkil edecektir. Bu itibarla, 5395 sayılı Çocuk Koruma Kanunu ${ }^{171}$ ve 6284 sayılı Ailenin Korunması ve Kadına Karşı Şiddetin Önlenmesine Dair Kanun ${ }^{172}$ kapsamında aile hayatına müdahale niteliğindeki

169 ZH and RH v Switzerland App No 60119/12 (ECHR, 8 December 2015), para 44

170 Concurring Opinion Of Judge Nicolaou, ZH and RH v Switzerland App No 60119/12 (ECHR, 8 December 2015) 15.

171 Çocuk Koruma Kanunu, Kanun Numaras1: 5395, Kabul Tarihi: 03.07.2005, RG 15.07.2005/25876.

172 Ailenin Korunması ve Kadına Karşı Şiddetin Önlenmesine Dair Kanun, Kanun Numarası: 6284, Kabul Tarihi: 08.03.2012, RG 20.03.2012/28239. 
söz konusu koruma tedbirlerinin; mümkün olduğunca, çocuğun, kamunun ve kamu sağlığının korunması meşru amaçlarının sağlanması bakımından "ölçülü” olmasına ve "aile hayatına saygı hakkının korunması" yükümlülüğüne bir ihlal teşkil etmeyecek nitelikte olmasına dikkat edilmesi gerekmektedir. Bu bağlamda; kanaatimizce; özellikle, anne olan çocuk ile bebeğinin ayrılmasına yol açmayacak, baba ile çocuğun etkin kişisel ilişki kurma hakkını tesis edecek ve anne ile babanın belirli şartlar çerçevesinde görüşmelerini temin edecek nitelikte tedbirlerin alınması yerinde olacaktır.

\section{Sonuç}

Türkiye çocuk yaşta evlilik uygulamasına karşı hükümler getiren, milletlerarası sözleşmelere ve Avrupa Konseyi'ne taraf bir devlet olması itibariyle, Türkiye'de bulunan Suriyeli çocuklar bakımından da, çocuk yaşta evlilik uygulamasına karşı her türlü önlemi alma yükümlülüğündedir. Ancak, Suriyelilerin 2011'den itibaren kitlesel akın ile Türkiye'ye giriş yapmış olmaları ve bu sebeple geçici koruma altına alınan bu kişilerin medeni halleri ve nüfus bilgilerinin beyana dayalı olması, Avrupa örneklerindekinin aksine, çocuk yaşta evliliklerle ilgili tam bir veri ve bilgiye sahip olunmasını engellediği gibi; mağdur çocuklara yönelik gerekli koruma tedbirlerinin alınmasını da engellemektedir. Dolayısıyla kanaatimizce, Türkiye'de Suriyelilerce gerçekleştirilen çocuk yaşta evliliklerle mücadelede ilk adım, bu verilerin sağlıklı bir şekilde toplanması ve mağdur çocuklara ulaşılması olmalıdır. İkinci adım ise, geçici koruma altındaki Suriyelilerin Türk toplumuna ve Türk hukukuna uyumlarının sağlanmasıdır. Bu kapsamda, toplumsal mağduriyetlerin önlenmesi adına, Türk hukukundaki evlenme, boşanma, nafaka ve velayet gibi aile hukukunun temel meselelerine ilişkin Türk Medeni Kanunu'nun ilgili hükümleri konusunda bilgilendirilmelerinin sağlanması gerekmektedir.

Çocuk yaşta evliliklerle mücadelede bir diğer yöntem normatif düzenlemelerdir. Tüm dünyada iltica hareketlerinin artması sebebiyle, çocuk yaşta evliliklerle mücadele etmek üzere, evlenme yaşına ve yabancı ülkede yapılan çocuk yaşta evliliklerin tanınmamasına yönelik mevzuat değişiklikleri tartışılmaktadır. Çalışmamızda bu kapsamda, İsviçre, Hollanda ve Alman hukuklarında bu yönde getirilen mevzuat değişikleri incelenmiştir. Bu bağlamda; kanaatimizce, İsviçre hukukunda olduğu gibi, Türk Medeni Kanununda da değişikliklere gidilerek; asgari evlenme yaşının istisnasız olarak 18 yaşa yükseltilmesi ve 18 yaş altı evliliklerin "mutlak butlan" sebepleri arasında açıkça düzenlenmesi yerinde olacaktır. Yapılacak değişiklikte; İsviçre ve Alman hukuklarındaki gibi, "çocuğun üstün menfaati”nin evliliğin devamını mecbur kılması halinin bir istisna olarak yer alması da, Türkiye'nin Avrupa Konseyi üyesi ve BM Çocuk Hakları Sözleşmesi’ne taraf bir ülke olması itibariyle uygun olacaktır. 
Yabancıülkedeyabancıhukukagöreyapılançocukyaşta evliliklerinTürkhukukunda tanınmasını engellemeye yönelik herhangi bir değişikliğe ise kanaatimizce gerek bulunmamaktadır. Zira İsviçre, Hollanda ve Alman hukuklarında, evlenme ehliyet ve şartlarının; yurt içinde yapılan evliliklerde, "eşlerin milli hukuku” yerine "evlenmenin yapıldığı ülke hukuku”na tabi kılınmasına ve yurt dışında yapılan evlililiklerde, çocuk yaşta evliliklerin tanınmamasına yönelik getirilen genel yasaklayıcı düzenlemelerle dolaylı olarak lex foriye tabi kılınmasına ilişkin düzenlemeler, uygulanacak hukukta "kamu düzenine aykırılık" değerlendirmesini işlevsiz hale getiren düzenlemelerdir. Halbuki; yetkili yabancı hukukun uygulanmasında, her bir somut olayın şartlarına göre değerlendirme yapma imkanı sunan "kamu düzenine aykırılık" istisnası, çocuk yaşta evliliklerde, "çocuğun üstün menfaati”nin gözetilmesine imkan vermektedir. Çocuklarla ilgili her uyuşmazlıkta "çocuğun üstün menfaati”nin korunması ise, BM Çocuk Hakları Sözleşmesinde her taraf devlete getirilen bir yükümlülüktür. $\mathrm{Bu}$ itibarla, kanaatimizce, "çocuğun üstün menfaati”nin gözetilmesi ve korunmasını sağlayan "kamu düzenine aykırılık" müdahalesi, çocuk yaşta evliliklerle mücadelede kanunlar ihtilafı hukuku bakımından en uygun hukuki araçtır.

Bu kapsamda, Türk hukukunda, yabancı ülkede yetkili yabancı hukuka tabi olarak yapılmış çocuk yaşta evliliklerin tanınmasında; Türk hukukunda istisnai de olsa 16 yaşını doldurmuş olanların evlenmesine imkan tanındığından, "kamu düzenine aykırılık" değerlendirmesi, kanaatimizce, tanıma (iptal davası) anında eşlerden en az birinin 16 yaşını doldurmamış olduğu evliliklerin tanınması bakımından söz konusu olmalı; tanıma anında eşlerin her ikisi de 16 yaşını doldurmuş ise, böyle bir evliliğin tanınması Türk kamu düzenine aykırılık gerekçesiyle reddedilmemelidir.

Tanıma anında eşlerden birinin 16 yaşını doldurmamış olduğu evlenmeler bakımından ise; asgari bir yaş sınırı çizilmemelidir. Bu evlenmelerin tanınmasında yapılacak Türk kamu düzenine aykırılık değerlendirmesinde, Türk toplumunun değerleri, Türk aile yapısı, kamu sağlığı, bireyin maddi-manevi varlığını koruma ve geliştirme hakkı ve toplumsal cinsiyet eşitliğinin korunması ile "çocuğun üstün menfaati"nin korunması arasında bir denge sağlanmalıdır. Özellikle mağdur çocuğun şahsi gelişimi ve üstün menfaati göz önünde bulundurularak evliliğin geçerliliği hakkında bir karar verilmeli ve bu anlamda somut olayda daha büyük mağduriyetlere sebebiyet verilmemelidir. Diğer taraftan; Türk Ceza Kanunu m 103(a) uyarınca "çocuğun cinsel istismarı" bakımından öngörülmüş olan 15 yaş sınırı da bu değerlendirmede göz önünde bulundurulmalı ve kanaatimizce, tanıma (iptal davası) anında eşlerden birinin 15 yaşını doldurmamış olması halinde, böyle bir evliliğin tanınması Türk kamu düzenine açıkça aykırı olduğu gerekçesiyle reddedilmelidir.

Türk kamu düzenine açıkça aykırılık teşkil ettiği değerlendirilen çocuk yaşta evliliklerin geçersizliğine ve bu geçersizliğin müeyyidesi ile sonuçlarına; MÖHUK m 
5 uyarınca, öncelikle yetkili yabancı hukukta bu yönde öngörülen kurallar var ise onlar uygulanmalı; yetkili yabancı hukukun evlenme yaşına ilişkin tüm hükümleri Türk kamu düzenine aykırı ise, örneğin, yetkili yabancı hukukta herhangi bir asgari evlenme yaşı veya buna ilişkin bir müeyyide öngörülmemişse, o halde Türk hukuku uygulanmalıdır.

Kamu düzenine aykırılık gerekçesiyle tanınmayan ve geçersiz olduğuna karar verilen yabancı hukuka tabi çocuk yaşta evliliklerde, AİHS m 8 kapsamında bir "aile hayatı" bulunup bulunmadığı değerlendirilmelidir. Somut olayda bir "aile hayatı" mevcut ise, çocuk mağdur hakkında Türk hukuku çerçevesinde alınacak koruma tedbirlerinin, "aile hayatına saygı hakkı"na ihlal teşkil etmeyecek "ölçülülük" ve nitelikte olmasına dikkat edilmelidir.

Geçici koruma altındaki Suriyeliler özelinde ise; kanaatimizce, bu kişiler, "vatandaşı oldukları devletin diplomatik himayesinden yararlanmayan kişiler" olarak MÖHUK m 4/1(a) kapsamında kabul edilmeli ve evlenme ehliyet ve şartlarına uygulanacak hukukta, Türkiye içinde ve Türkiye'ye gelmeden önce yaptıkları evlilikler arasıda ikili bir ayrıma gidilmelidir. Türkiye'de iken yaptıkları evliliklerde, MÖHUK m 13/1 uyarınca evlenme ehliyet ve şartlarına ve dolayısıyla evlenme yaşına, "eşlerden her birinin evlenme anındaki milli hukuku" olarak, Suriyeli eş bakımından, MÖHUK m 4/1(a) gereği Türk hukuku uygulanmalıdır.

Türkiye'ye gelmeden önce yaptıkları evliliklerde ise; MÖHUK m 4/1(a) bendi uygulama alanı bulmayacağından, MÖHUK m 13/1 uyarınca evlenme yaşına, "eşlerden her birinin evlenme anındaki milli hukuku" olarak, Suriyeli eş bakımından, vatandaşı oldukları Suriye hukuku uygulanmalıdır. Suriye hukukunun muhtevasının, resmi ve diplomatik yollardan temin edilememesi halinde, Türk mahkemelerince, taraf yardımı, bilirkişilik, hukuki mütalaa ve üniversitelerden bilgi alma gibi, yabancı hukukun temine yönelik diğer yollara başvurularak Suriye hukukunun teminine çalışılmalıdır.

Geçici koruma altındaki Suriyelilerin Türkiye'ye gelmeden önce yaptıkları Suriye hukukuna tabi çocuk yaşta evliliklerin tanınmasında; tanıma (iptal davası) anında eşlerden biri 16 yaşını doldurmamış ise, bu evliliğin tanınmasının Türk kamu düzenine aykırı olup olmadığ 1 değerlendirilmeli ve bu değerlendirmede, "çocuğun üstün menfaatinin korunması" ilkesinin gözetilmesi gereği unutulmamalıdır. Tanıma (iptal davası) anında Suriyeli eşlerden birinin 16 yaşını doldurmamış olduğu Suriye hukukuna tabi evliliklerin tanınması, Türk kamu düzenine açıkça aykırı bulunur ise, bu evliliklerin geçersizliğine Suriye hukuku uygulanmalı ve buna göre bu evliliklerin "mutlak butlan"la batıl olduğuna karar verilmelidir. Bu itibarla; geçici koruma altındaki Suriyelilerce Suriye hukukuna göre yapılmış çocuk yaşta evliliklerin müeyyidesi "mutlak butlan" olarak öngörüldügünden; bu evlilikler hakkında iptal davası açma şartları bakımından, Türk Medeni Kanunu'da yer alan evlenmenin "mutlak butlanına" 
ilişkin hükümler uygulanmalı ve böyle bir evliliğin resmi makamlarca tespiti halinde iptal davasının açılabilmesi için Cumhuriyet Başsavcılıkları bilgilendirilmelidir.

Ayrıca, çalışmamızda, MÖHUK m 4/1(a) hükmünün konuluş amacı ve YUKK hükümleri ile daha uyumlu bir hale getirilmesi adına, hükümde bir değişiklik yapılarak, "mülteci" kavramı yerine, "vatandaşı olduğu ülkenin diplomatik himayesinden yararlanamaması sebebiyle koruma talep eden veya sağlanan kişiler" ifadesinin getirilmesinin daha uygun olacağı değerlendirilmiştir.

Hakem Değerlendirmesi: Dış bağımsız.

Çıkar Çatışması: Yazar çıkar çatışması bildirmemiştir.

Finansal Destek: Yazar bu çalışma için finansal destek almadığını beyan etmiştir.

Peer-review: Externally peer-reviewed.

Conflict of Interest: The author has no conflict of interest to declare.

Grant Support: The author declared that this study has received no financial support. 


\section{Bibliyografya/Bibliography}

Akıncı Z ve Demir Gökyayla C, Milletlerarası Aile Hukuku (Vedat Kitapçılık 2010).

Akıntürk T ve Karaman D, Türk Medeni Hukuku Aile Hukuku Cilt 2 (20. Bası, Beta 2017).

Altıparmak AK, İngiliz, Avrupa Birliği ve Türk Hukukunda Mirasa Uygulanacak Hukuk (Oniki Levha 2017).

Arslan Öncü G, Avrupa İnsan Hakları Sözleşmesinde Özel Yaşamın Korunması Hakkı (Beta 2011).

Aydın E, ‘Avrupa Birliği Mevzuatında Güvenli Üçüncü Ülke Kavramı ve Türkiye-AB Geri Kabul Anlaşmasına Yansımaları' (2018) 38(1) PPIL 11-40.

Çelikel A ve Erdem BB, Milletlerarası Özel Hukuk (15. Bas1, Beta 2017).

Çelikel A ve Öztekin Gelgel G, Yabancılar Hukuku (24. Bas1, Beta 2018).

Çiçekli B, Yabancılar ve Mülteci Hukuku (6. Bası, Seçkin 2016).

Dethloff N, 'Child Brides on The Move: Legal Responses to Culture Clashes' (2018) 32(3) International Journal of Law, Policy and The Family 302-315 < https://doi.org/10.1093/lawfam/ eby008> erişim tarihi 11 February 2020.

Doğan V, Türk Yabancılar Hukuku (3. Bas1, Savaş Yayınevi 2018).

Doğan V, Milletlerarası Özel Hukuk (5. Bası, Savaş Yayınevi 2019).

Dural M, Öğüz T ve Gümüş MA, Türk Özel Hukuku Aile Hukuku Cilt III (14edn, Filiz Kitapevi 2019).

Ekşi N, Yargıtay Kararları Işı̆̆ııda Milletlerarası Miras Hukuku (Beta 2013).

Ekşi N, Yabancılar ve Uluslararası Koruma Hukuku (4. Bas1, Beta 2016).

Ekşi N, Milletlerarası Özel Hukukta Medenî Olmayan Evliliklerin ve Adlî Olmayan Boşanmaların Tanınmast (Beta 2012).

Erdoğan Bİ, '5718 Sayılı MÖHUK Uyarınca Tenkis Davasında Uygulanacak Hukukun Kamu Düzeni Bakımından Değerlendirilmesi ve Yetkili Mahkeme' (2018) 20(1) DEÜHFD 397-430.

Gelgel G, Devletler Özel Hukukunda Çocuk Hukukundan Doğan Problemler (Beta 2012).

Gençcan ÖM, Aile Mahkemesi Davaları (2. Bası, Yetkin Yayınları 2016).

Giray FK, Milletlerarası Özel Hukukta Kaçırılan ve Alıkonan Çocukların İadesi (Beta 2010).

Giray FK, 'Milletlerarası Özel Hukuk Hakkaniyetinin 5718 Sayılı MÖHUK Kapsamında Değerlendirilmesi' (2011-2012) 7(9) YÜHFD (Prof. Dr. Erhan Adal'a Armağan) 555-577.

Hatemi H ve Serozan R, Aile Hukuku (Filiz Kitapevi 1993).

Keskin D, ‘Küçük Yaşta Evlenmenin Müeyyidesi' (2011) 15(4) GÜHFD 65-83.

Huysal B, Devletler Özel Hukukunda Velayet (Legal 2005).

Kılıçoğlu AM, Aile Hukuku (3. Bası, Turhan Kitabevi 2017).

Kusserow J, 'Regulating Child Marriage: Germany's Latest Foray and Possible Lessons For Canada', (Canadian Icon) <http://canadianicon.org/regulating-child-marriage-germanys-latestforay-and-possible-lessons-for-canada/\#_ednref12> erişim tarihi 11 February 2020.

Daad Mousa, 'Syrian Personal Status Law' (Friedrich-Ebert-Stiftung 2018) $4<$ http://library.fes.de/ pdf-files/bueros/beirut/14969.pdf> erişim tarihi 21 February 2020.

Nomer E, Devletler Hususi Hukuku (22. Bas1, Beta 2017).

Oğuzman K ve Dural M, Aile Hukuku (2. Bası, Filiz Kitapevi 1998).

Öztan B, Aile Hukuku (6. Bas1, Turhan Kitabevi 2015).

Özcan M, AB Siğınma Hukuku (USAK 2006). 
Sayman Y, Türk Devletler Hususi Hukukunda Evlenmenin Kuruluşu (Fakülteler Matbaas1 1992).

Serozan R, Çocuk Hukuku (2. Bası, Vedat Kitapçılık 2017).

Şanlı C, Esen E ve Ataman-Figanmeşe İ, Milletlerarası Özel Hukuk (7. Bası, Beta 2019).

Tekinalp G ve Uyanık A, Milletlerarası Özel Hukuk Bağlama Kuralları (12. Bası, Vedat Kitapçılık 2016).

Tekinay SS, Türk Aile Hukuku (7. Bas1, Filiz Kitapevi 1990).

Uluocak N, Milletlerarasi Özel Hukuk Dersleri (2. Bas1, Filiz Kitabevi 1989).

van Eijk E, Family Law in Syria: Patriarchy, Pluralism and Personal Status Laws (IB Tauris, 2016).

Wijffelman A, 'Child marriage and Family Reunification: An Analysis under the European Convention on Human Rights and Dutch Forced Marriage Prevention Act' (2017) 35(2) Netherlands Quarterly of Human Rights 104-121 <https://journals.sagepub.com/doi/ pdf/10.1177/0924051917708384> erişim tarihi 11 February 2020.

CARE International UK, 'To Protect Her Honour-Child marriage in emergiencies-the fatal confusion between protecting girls and sexual violence' (2015) $7<\mathrm{https}$ ://insights.careinternational.org.

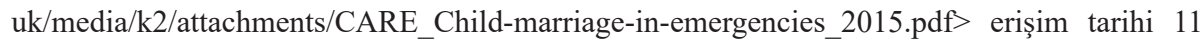
February 2020.

ECPAT International, 'Preventing and Eliminating Child, Early and Forced Marriage: challenges, achievements, best practices \& implementation gaps', (2013) < https://www.ohchr.org/ layouts $/ 15 /$ WopiFrame.aspx? sourcedoc $=\% 2$ FDocuments $\% 2$ FIssues $\% 2$ FWomen $\% 2 \mathrm{FWRGS} \%$ 2FForcedMarriage $\% 2 \mathrm{FNGO} \% 2 \mathrm{FECPATInternational \% 2Edoc \& action=view}>$ erişim tarihi 11 February 2020 .

LANDINFO, 'Report Syria: Marriage Legislation and Traditions' (2018) 7-9 < https://landinfo.no/ wp-content/uploads/2018/10/Report-Syria-Marriage-legislation-and-traditions-22082018.pdf> erişim tarihi 21 February 2020.

PACE, 'Resolution on Forced Marriages and Child Marriages' (2005) Resolution No 1468.

PACE, 'Resolution on Forced Marriage in Europe' (2018) Resolution No 2233.

TÜIK, Republic of Turkey Ministry of Family and Social Policy, 'Family Structure Survey' (2016) $<$ http://www.turkstat.gov.tr/PreHaberBultenleri.do?id=21869> erişim tarihi 11 February 2020.

TÜIK, ‘İstatistiklerde Çocuk’ (2018) < http://tuik.gov.tr/PreHaberBultenleri.do?id=30708> erişim tarihi 11 February 2020.

UN, ‘A Study of Statelessness' (1949) $7<$ https://www.refworld.org/pdfid/3ae68c2d0.pdf> erişim tarihi 11 February 2020.

International Refugee Organization, Constitution of the International Refugee Organization, 62 Stat. 3037, Treaties and Other International Act Series 1846.

UN CEDAW/UN CRC, 'Joint General Comment No 31 of the CEDAW / No 18 of the CRC on the Rights of the Child on harmful practices', (2014) UN-Doc CEDAW/C/GC/31-CRC/C/GC/18.

UN CEDAW, 'General Comment No 21: Equality in Marriage and Family Relations' (1994) UNDoc A/39/38.

UN General Assembly, 'Status of Women in Private Law: Customs, Ancient Laws and Practices Affecting the Human Dignity of Women', 17 December 1954, A/RES/843.

UN HRC, 'Report of the Special Rapporteur on Torture and Other Cruel, Inhuman or Degrading Treatment or Punishment' (2016) UN-Doc A/HRC/31/57.

UN OHCHR, 'Preventing and Eliminating Child, Early and Forced Marriage' (2014) UN-Doc A/ $\mathrm{HRC} / 26 / 22$. 
UN WOMEN, 'Türkiye'de Geçici Koruma Altındaki Suriyeli Kadın ve Kız Çocukların İhtiyaç Analizi' (2018) Grafik 8 <http://sgdd.org.tr/wp-content/uploads/2018/08/The_Needs_ Assessment_TR_WEB.pdf $>$ erişim tarihi 11 February 2020.

UN WOMEN, 'Inter-Agency Assessment: Gender-Based Violence and Child Protection Among Syrian Refugees in Jordan with a Focus on Early Marriage' (2013) $29<$ https://data2.unhcr.org/ ar/documents/download/39522> erişim tarihi 11 February 2020.

UNHCR, 'The Refugee Convention 1951: The Travaux préparatoires analysed with a Commentary by Dr. Paul Weis' (1990) 64-66, 80 <https://www.refworld.org/docid/53e1dd114.html> erişim tarihi 11 February 2020.

UNHCR Evaluation Service, 'Evaluation of UNHCR's Emergency Response to the influx of Syrian Refugees into Turkey' (2016) 52-55<https://www.unhcr.org/58a6bbca7.pdf > erişim tarihi 11 February 2020.

UNFPA, 'Marrying Too Young End Child Marriage' (2012) $11<$ https://www.unfpa.org/sites/ default/files/pub-pdf/MarryingTooYoung.pdf $>$ erişim tarihi 11 February 2020.

UNICEF Data, 'Child Marriage' (2018) < https://data.unicef.org/topic/child-protection/childmarriage/> erişim tarihi 11 February 2020.

UNICEF, 'A Study on Early Marriage in Jordan' (2014) 8, 22-23 <https://reliefweb.int/sites/ reliefweb.int/files/resources/UNICEFJordan_EarlyMarriageStudy2014.pdf $>$ erişim tarihi 11 February 2020.

Servet Yanatma, 'Türkiye'de 2018'de 11 binden fazla çocuk doğum yapt1; 167'si 15 yaşından küçük' Euronews (5 July 2019) <https://tr.euronews.com/2019/07/05/turkiye-de-2018-de-11-bindenfazla-cocuk-dogum-yapti-167-si-15-yasindan-kucuk-tuik-nufus> erişim tarihi 11 February 2020.

AFP, 'Germany to crack down on forign child marriages' (The Local Germany, 5 April 2017) $<$ https://www.thelocal.de/20170405/germany-cracks-down-on-foreign-child-marriages $>$ erişim tarihi 11 February 2020.

The Draft Legislation on Child Marriage and Private International Law: An Interview with Institute Director Jürgen Basedow, <https://www.mpipriv.de/files/pdf4/Interview_with_Jrgen_ Basedow_The_Draft_Legislation_on_Child_Marriage_and_Private_International_Law1.pdf $>$ 07 February 2020. 
